UNIVERSIDADE DE SÃO PAULO

FACULDADE DE FILOSOFIA, LETRAS E CIÊNCIAS HUMANAS DEPARTAMENTO DE CIÊNCIA POLÍTICA PROGRAMA DE PÓS-GRADUAÇÃO EM CIÊNCIA POLÍTICA

KAROLINE DA CUNHA ANTUNES

Democratização, Liberalização Econômica e Processo

Decisório em Política Externa: um estudo de caso sobre o papel

do congresso mexicano nas legislaturas de 1994 a 2006

São Paulo

2009 
UNIVERSIDADE DE SÃO PAULO

FACULDADE DE FILOSOFIA, LETRAS E CIÊNCIAS HUMANAS DEPARTAMENTO DE CIÊNCIA POLÍTICA PROGRAMA DE PÓS-GRADUAÇÃO EM CIÊNCIA POLÍTICA

\section{Democratização, Liberalização Econômica e Processo \\ Decisório em Política Externa: um estudo de caso sobre o papel do congresso mexicano nas legislaturas de 1994 a 2006}

Dissertação apresentada ao Departamento de Ciência Política da Faculdade de Filosofia, Letras e Ciências Humanas da Universidade de São Paulo, para a obtenção do título de mestre em Ciência Política

Orientador: Prof. Dr. Amâncio Jorge Silva Nunes de Oliveira

São Paulo

2009 
FOLHA DE APROVAÇÃO

\section{Karoline da Cunha Antunes}

\section{Democratização, Liberalização Econômica e Processo Decisório em Política Externa: um estudo de caso sobre o papel do congresso mexicano nas legislaturas de 1994 a 2006}

Dissertação apresentada ao Programa de Pós-Graduação do Departamento de Ciência Política da Faculdade de Filosofia, Letras e Ciências Humanas da Universidade de São Paulo, sob a orientação do Prof. Dr. Amâncio Jorge Silva Nunes de Oliveira, para a obtenção do título de mestre.

Aprovada em:

Banca Examinadora

Prof. Dr. Amâncio Jorge Silva Nunes de Oliveira (orientador) Universidade de São Paulo

Profa. Dra. Janina Onuki

Universidade de São Paulo

Profa. Dra. Simone Diniz

Universidade Federal de São Carlos 
"The initiative in foreign affairs, which the President possesses without any restriction whatever, is virtually the Power to control them absolutely".

Woodrow Wilson, Presidente norte-americano

"La acción del Senado de la República en matéria de relaciones exteriores há transcendido, con mucho, el limitado ámbito de las funciones de análisis y aprobación. Es necesario que, de acuerdo com el espírito de nuestra propia Carta Magna, se incorporen formalmente a Ella aquellos elementos que la realidad misma ha ido sumando al campo de acción que el Senado puede tener en la política exterior de nuestro país".

Fernando Solana, Ex-Presidente da Comissão de Relações

Exteriores do Senado mexicano 


\section{RESUMO}

O presente trabalho analisa o papel desempenhado pelo Congresso Mexicano em temas de política externa no período de 1994-2006 (LVI a LIX Legislaturas), correspondente aos mandatos de Ernesto Zedillo e Vicente Fox, à luz dos processos de liberalização econômica e política experimentados pelo país nas últimas décadas.

Adotando como referencial os indicadores nível de atividade e nível de divergência, a hipótese formulada é que, durante o período estudado, o Congresso mexicano apresentou um elevado grau de ativismo, mas sua assertividade foi baixa. Nos momentos de maior confronto com o Executivo, o Congresso demonstrou uma reduzida capacidade institucional de impor suas preferências. As limitações dos congressistas para atuar no domínio da política externa estariam relacionadas a fatores estruturais, como os custos de rejeição de um tratado internacional, e conjunturais, a exemplo da dificuldade de construir consensos no interior das Casas Legislativas a respeito de qual seria o papel do Congresso nesta seara.

Palavras-Chave: Congresso Mexicano, Política Externa, Liberalismo, Processo Decisório, Relações Executivo-Legislativo, Ativismo, Assertividade 


\begin{abstract}
This work analyses the role of Mexican Congress in foreign policy issues during the period of 1994-2006 (LVI-LIX Legislature), corresponding to the presidencies of Ernesto Zedillo and Vicente Fox, based on the processes of economic and political liberalization faced by the country in the last decades.

Taking into account indicating levels of activity on foreign policy issues and disagreement over foreign policy, the hypothesis formulated is that, during the period studied, the Mexican Congress has shown a high level of activism, however its assertiveness was low. In the moments of confrontation with Executive, the Congress has shown little institutional capacity to impose its preferences. The congressmen limitations to act in the realm of foreign policy could be related to structural factors, such as the costs of an international treaty's rejection, or conjunctural, such as the difficult of constructing consensus in the Upper and Low chambers about what Congress's role in foreign affairs issues should be.
\end{abstract}

Keywords: Mexican Congress, Foreign Policy, Liberalization, Decision Making Process, Executive-Legislative Relations, Activism, Assertiveness 


\section{SUMÁRIO}

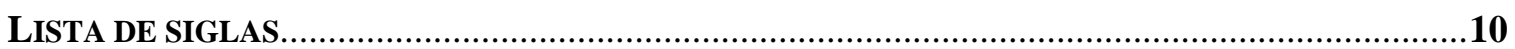

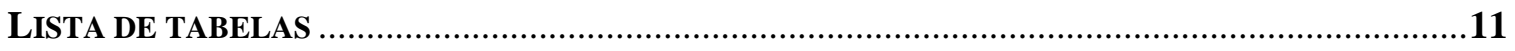

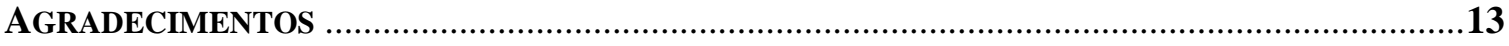

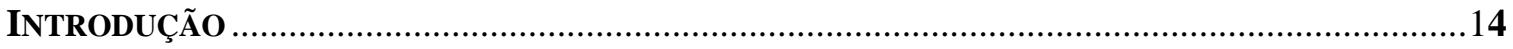

\section{Capítulo 1. Revisão da literatura: O Estado da Arte do Debate ACadêmico}

Seção I - Democratização, Liberalização Econômica e Geometria do Processo Decisório .............27

Seção II - Relações Executivo-Legislativo no Campo da Política Externa .........................................31

1. As Competências dos Parlamentos em Política Externa e os Fatores de Dominância do

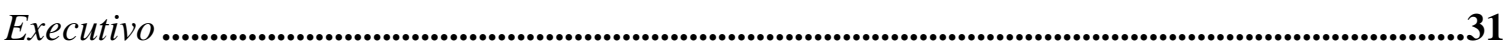

2. As Falácias Eleitoral, Tecnocrata e dos Adversários e os Incentivos dos Congressistas............34

3. Contribuições do Debate Norte-Americano e o Estado da Arte da Literatura Mexicana .........36

\section{Capítulo 2. A Evolução das Relações Entre Executivo e Legislativo no MÉXICO}

Seção I - Antecedentes............................................................................................................................................44

1. O Processo de Liberalização Econômica.......................................................................................................44

1.1. A Condução Política do Processo de Liberalização Econômica .................................................46

2.0. O Processo de Democratização ...................................................................................................48

2.1. Do Autoritarismo à Democracia Presidencialista sob Governo Dividido: a Nova

Configuração do Sistema Político Mexicano ..................................................................................................48

2.2 Do Sistema de Partido Hegemônico ao Multipartidarismo: A Nova Configuração do Sistema

Partidário Mexicano ....................................................................................................................................50

Seção II - Impactos da Abertura Política e Econômica sobre o Processo Decisório em Política

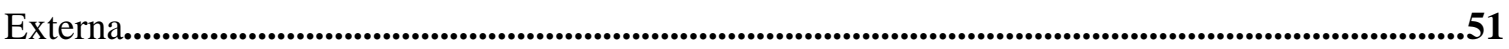

1. Geometria do Processo Decisório e os Novos Atores ............................................................51

2. Evolução das Competências Constitucionais em Matéria de Política Externa ...........................53 


\section{Capítulo 3. Análise Empírica: As Variáveis Nível de Atividade e Nível de DIVERGÊNCIA}

1. Aspectos Teóricos: Conceituando o Comportamento do Congresso .....

2. Instrumentos de Influência do Congresso: Poder de Ratificação, Legislação Substantiva,

Legislação Procedimental, o Poder de Controle sobre o Dispêndio e os Meios Indiretos.

Seção I - A Variável Nível de Atividade do Congresso - Diagnóstico do Ativismo .......................75

1. Breves Considerações sobre o Processo Legislativo Mexicano....................................................76

2. Legislação Substantiva ................................................................................................................................84



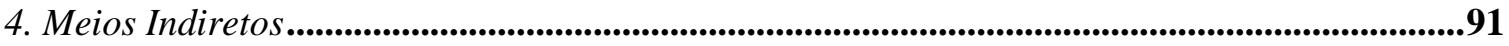

Seção II - A Variável Nível de Divergência - Diagnóstico da Assertividade

1. A Divergência entre os Partidos: Plataformas Eleitorais e a Posição dos Principais Partidos

Mexicanos em Temas de Política Externa.............................................................................99

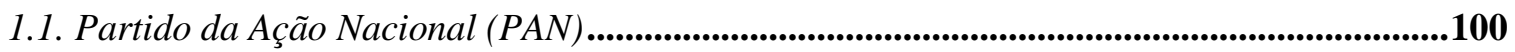

1.2. Coalizão para o Bem de Todos .........................................................................................................101

1.3. Aliança para o México ...............................................................................................................................102

2. A Divergência entre os Poderes ..............................................................................................................103

2.1. O Poder de Veto do Congresso Mexicano........................................................................................103

2.1.1. Ratificação de Tratados Internacionais e Nomeações Diplomáticas.....................................103

2.1.1.2. Procedimento para a Aprovação de um Tratado Internacional no México......................103

2.1.1.3. As Votações de Tratados Internacionais e de Nomeações Diplomáticas no Senado

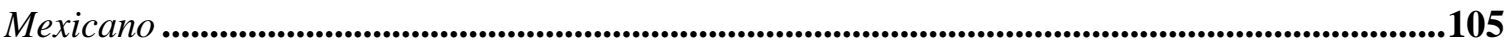

2.1.2 Autorização para a Saída do Presidente do Território Nacional, para a Saída de Tropas do Território Nacional e para o Uso de Condecorações.

2.2. Principais Pontos de Divergência entre o Executivo e o Legislativo em Matéria de Política

Externa no Período Analisado ...........................................................................................................................122

2.2.1. A Relação com os Estados Unidos ......................................................................................123

2.2.2. Imigração ...................................................................................................................................124

2.2.3. Crises Diplomáticas com os Países Latino-Americanos ......................................................125

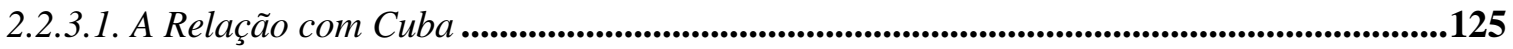


2.2.3.2. As Crises com Argentina e Venezuela .....................................................................................128

2.3. O Saldo da Disputa entre os Poderes................................................................................................130

Seção III - Análise de Casos .........................................................................................................139

1. Divisão de Preferências entre as Casas do Congresso: a Votação da Lei sobre a Aprovação de Tratados em Matéria Econômica .............................................................................................................140

2. O Papel da Câmara dos Deputados: o Caso da Taxação do Xarope de Milho........................141

3. Acordos Executivos e a Negociação da ASPAN...........................................................................144

\section{Capítulo 4. Encaminhamentos para a Ampliação da Agenda de Pesquisa: Possíveis Fatores que Limitam a Atuação do Congresso Mexicano na Formulação de Política EXTERna}

1. A Aprovação de Tratados Internacionais e os Custos da Rejeição.............................................149

2. O Impacto do NAFTA e os Efeitos Decrescentes dos Tratados após a Abertura Econômica $\mathbf{1 5 2}$

3. A Dificuldade de Construção de Consensos no Interior Das Casas Legislativas sobre o Papel

do Congresso em Política Externa ...................................................................................154

4. O Uso Doméstico das Atribuições do Congresso........................................................................156

\section{CONCLUSÃo}

1. Atualização do Debate: Breves Considerações sobre os Dois Primeiros Anos do Governo de Felipe Calderón (2007-2008).....................................................................................158

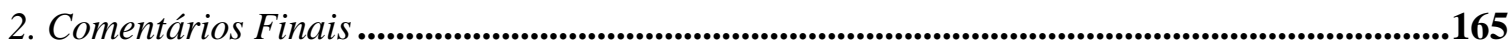

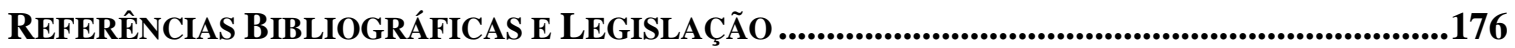




\section{LISTA DE SIGLAS}

APEC - Associação Pacífica de Cooperação Econômica

ASPAN - Aliança para a Prosperidade e Segurança da América do Norte

CD - Convergência pela Democracia

EFTA - Associação Européia de Livre Comércio

FDN - Frente Democrática Nacional

IND - Independente

NAFTA - Área de Livre Comércio da América do Norte

OCDE - Organização para Cooperação e Desenvolvimento

OMC - Organização Mundial do Comércio

OMPI - Organização Mundial da Propriedade Intelectual

ONU - Organização das Nações Unidas

PAN - Partido da Ação Nacional

PAS - Partido Aliança Social

PRD - Partido da Revolução Democrática

PRI - Partido Revolucionário Institucional

PSN- Partido Sociedade Nacionalista

PT - Partido do Trabalho

PVEM - Partido Verde Ecologista do México

SECOFI - Secretaria de Comércio e Desenvolvimento Industrial

SRE - Secretaria de Relações Exteriores

UE - União Européia 


\section{LISTA DE TABELAS}

TABela 1 - Instituições e Distribuição de Poder no México, 1982-2000..........................52

TABEla 2 - Câmara dos Deputados - $1^{\text {o }}$ Triênio do Governo Zedillo (1994-1997) .........78

TABEla 3 - Senado - $1^{\text {o }}$ Triênio do Governo Zedillo (1994-1997).......................................79

TABElA 4 - Câmara dos Deputados - 2º Triênio do Governo Zedillo (1997-2000) .........80

TABELA 5 - Senado - 20 Triênio do Governo Zedillo (1997-2000).................................81

TABEla 6 - Câmara dos Deputados - $1^{\text {o }}$ Triênio do Governo Fox (2000-2003)...............82

TABELA 7 - Câmara dos Deputados $-2^{\circ}$ Triênio do Governo Fox (2003-2006)................82

TABEla 8 - Senado - Sexênio do Governo Fox (2000-2006) ................................................83

TABELA 9 - Iniciativas substantivas em matéria de relações exteriores. ............................86

TABELA 10 - Iniciativas procedimentais em matéria de relações exteriores.....................88

TABELA 11 - Iniciativas da Câmara dos Deputados em matéria de aprovação de tratados internacionais nas LVIII e LIX Legislaturas ..............................................................88

TABELA 12 - Pontos de Acordo em matéria de relações exteriores apresentados na LVI

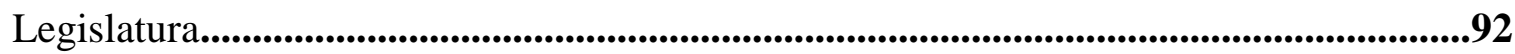

TABELA 13 - Pontos de Acordo em matéria de relações exteriores apresentados na LVII

Legislatura..............................................................................................................................................93

TABELA 14 - Pontos de Acordo em matéria de relações exteriores apresentados na LVIII

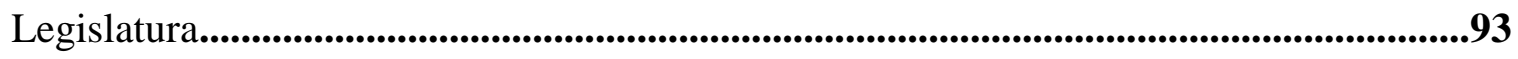

TABELA 15 - Pontos de Acordo em matéria de relações exteriores apresentados na LIX

Legislatura..........................................................................................................................94

TABELA 16 - Acordos Parlamentares em matéria de relações exteriores apresentados na

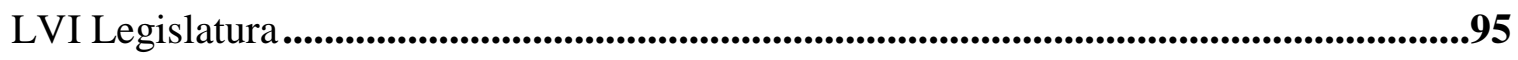

TABELA 17 - Acordos Parlamentares em matéria de relações exteriores apresentados na

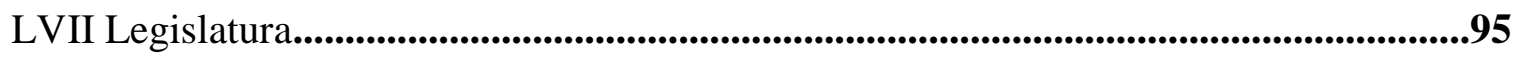

TABELA 18 - Acordos Parlamentares em matéria de relações exteriores apresentados na

LVIII Legislatura ....................................................................................................................96

TABELA 19 - Acordos Parlamentares em matéria de relações exteriores apresentados na

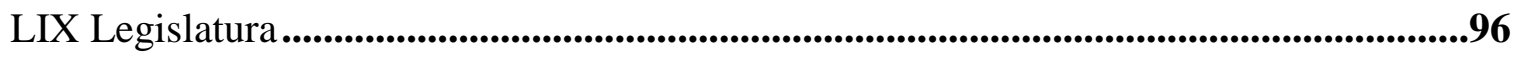

TABELA 20 - Nomeações diplomáticas submetidas à votação ........................................106

TABELA 21 - Instrumentos Internacionais..............................................................................110

TABELA 22 - Instrumentos Internacionais não aprovados por unanimidade....................113 
TABELA 23 - Autorização para viagens internacionais ..........................................................120

TABELA 24 - Autorização para o uso e recebimento de condecorações estrangeiras .....121

TABELA 25 - Votação na Câmara dos Deputados da Lei sobre Aprovação de Tratados

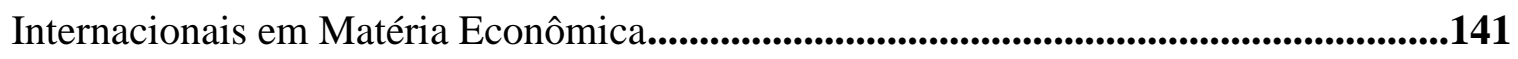

TABELA 26 - Ratificações pelo Congresso na LX Legislatura - ....................................... 162

TABELA 27 - Iniciativas em matéria de relações exteriores na LX Legislatura -

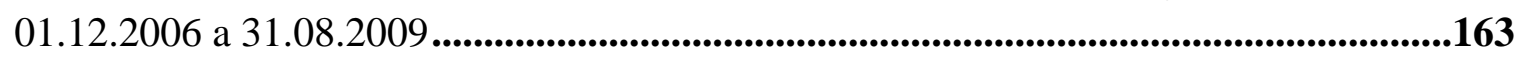

TABELA 28- Pontos de Acordo em matéria de relações exteriores na LX Legislatura -

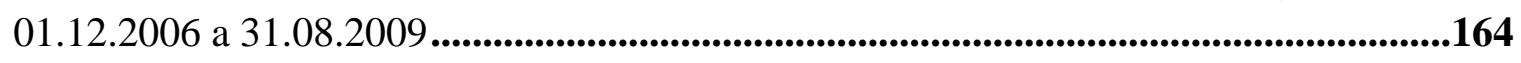

TABELA 29 - Acordos Parlamentares em matéria de relações exteriores na LX

Legislatura - 01.12.2006 a 31.08.2009....................................................................................165 


\section{AGRADECIMENTOS}

A concretização deste trabalho não teria sido possível sem a contribuição de inúmeras pessoas que, cada qual à sua maneira, fizeram com que mais este projeto se tornasse realidade. A estas dedico a presente dissertação de mestrado e dirijo os meus sinceros agradecimentos.

Um agradecimento especial à minha mãe e aos meus avôs maternos, grandes incentivadores dos meus estudos desde a mais tenra idade, os quais não pouparam esforços para que eu tivesse a melhor educação possível. Sem o afeto e o apoio incondicionais do meu núcleo familiar mais próximo, não teria vencido mais esta etapa em minha vida.

Agradeço ao meu orientador, Amâncio, e à Professora Janina Onuki, que me estimularam a prestar a prova do mestrado e deram todo o apoio para que eu pudesse enfrentar as difíceis fases do processo de seleção. Tive o prazer de conviver com os ensinamentos destes dois professores no Centro de Estudos de Negociações Internacionais (CAENI), fundamentais para o meu desenvolvimento acadêmico.

Aliás, foi durante o breve, mas enriquecedor, período em que participei de alguns projetos no CAENI, que pude amadurecer a idéia para o projeto de pesquisa que culminou nesta dissertação de mestrado. Cabe um agradecimento aos colegas de CAENI deste período, Pedro, Emanuel e Guilherme Gamba, pelo compartilhamento de idéias.

Agradeço aos amigos que fiz durante a pós-graduação, em especial, ao Gui Casarões, companheiro de infindáveis conversas no ônibus no caminho para casa, e ao Bruno Botti, companheiro de estudos do México, cujas indicações bibliográficas, comentários e sugestões foram de inestimável valia.

Agradeço aos meus amigos de longa data, Francesco, Paulinha, Nadim, Mary, que, direta ou indiretamente, acompanharam todo o processo de desenvolvimento deste trabalho e foram uma fonte contínua de apoio e incentivo.

Agradeço também ao meu namorado que soube ser compreensivo nas ocasiões em que tive que me isolar do mundo para escrever e que me deu forças nos momentos mais difíceis. 


\section{INTRODUÇÃO}

A presente dissertação de mestrado tem como objeto de análise o papel desempenhado pelo Congresso do México, em especial pelo Senado, em temas de política externa nos períodos de 1994/1997 (LVI Legislatura'), 1997/2000 (LVII Legislatura), 2000/2003 (LVIII Legislatura) e 2003/2006 (LIX Legislatura), à luz dos processos de liberalização econômica e democratização política experimentados pelo país. As legislaturas estudadas compreendem os governos dos Presidentes Ernesto Zedillo Ponce de León (1994-2000) e Vicente Fox (2000-2006).

O recorte temporal da análise, calcado nas legislaturas e não nos governos, vai ao encontro do foco central do trabalho, a atividade do Congresso mexicano em política externa, embora a relação com o Executivo também seja considerada. As quatro legislaturas se referem a duas composições distintas do Senado, que concentra as maiores atribuições na área internacional: as duas primeiras com maioria absoluta do Partido Revolucionário Institucional (1994-2000) e as duas últimas sem partido majoritário, com predomínio de senadores do Partido da Ação Nacional (2000-2006).

Seguindo o escorço teórico dos analistas de política externa, as atenções estarão voltadas para o estudo do comportamento de atores específicos que moldam a política externa e não para os Estados enquanto meras abstrações. A idéia central é que as decisões no plano internacional são decorrentes de ações individuais ou coletivas realizadas por tomadores de decisão, que competem pela imposição de preferências no espaço político. Por conseguinte, serão incorporadas variáveis domésticas à análise, tais como o desenho institucional do sistema de tomada de decisão e a atuação dos partidos políticos dentro da estrutura de poder do Estado.

A adoção desta perspectiva teórica implica na rejeição dos pressupostos básicos do realismo clássico (Morgenthau) e do realismo estrutural das relações internacionais

\footnotetext{
${ }^{1}$ Cada legislatura corresponde a um período de três anos, sendo instalada em $1^{\circ}$ de setembro do ano da realização das eleições e encerrada três anos depois, no dia 31 de agosto. Os senadores no México são eleitos por um período de seis anos, isto é, duas legislaturas. São ao todo 128 senadores. Cada um dos 31 distritos e o Distrito Federal elegem 2 senadores cada por sistema majoritário, mais um que é atribuído à primeira minoria. Os 32 senadores restantes são eleitos pelo sistema proporcional. Os deputados são eleitos a cada três anos, sendo vedada a reeleição. São ao todo 500 deputados, 300 eleitos pelo sistema majoritário, com distritos eleitorais uninominais, e 200 eleitos pelo sistema de representação proporcional.
} 
(Waltz). Refuta-se o argumento de uma suposta especificidade da política externa - a clássica divisão entre temas de alta e baixa política - calcada nos postulados do estado unitário (tradicional idéia da "bola de bilhar"), com interesse nacional definido pela estrutura; e da distinção entre os campos externo e interno, que elimina de seu modelo causal os fatores domésticos, a fim de adotar uma estrutura de análise mais complexa.

Conforme sustenta Milner (1997), a noção de interesse nacional, longe de ser um conceito previamente determinado, é um objeto de conflito; a política externa é o resultado de um jogo estratégico entre atores domésticos que lutam pelo poder interno. $\mathrm{O}$ interesse nacional é, assim, produto das preferências e dos interesses da coalizão vencedora no âmbito da política doméstica.

Alisson (1971), com seu modelo de "política burocrática", foi um dos primeiros autores a questionar a representação do ator unitário, pondo em xeque a artificial separação entre o externo e interno, isto é, entre a política externa e a política doméstica.

A relação entre os planos interno e externo no processo de tomada de decisão encontrou sua expressão mais bem acabada no famoso modelo de Putnam (1988) do jogo de dois níveis. Segundo Lima (2000), a inovação do modelo consistiria não apenas na introdução da causalidade doméstica na explicação de resultados internacionais, como também em apontar para a necessidade de ratificação interna de compromissos internacionais quando estes envolverem questões distributivas. Os custos internos levariam à mobilização dos atores afetados, trazendo para a esfera pública a discussão sobre a política externa.

Neste ponto, de grande valia são os trabalhos de Milner (idem) e Martin (2000), os quais buscam analisar o processo de formulação de política externa a partir de seus condicionantes domésticos, isto é, de interesses capitaneados por atores que sofrem, em alguma medida, os efeitos das ações internacionais do Estado e, portanto, estão motivados a influenciar de alguma forma o processo de tomada de decisão, a exemplo dos partidos políticos e sindicatos.

Para Milner (idem), a análise dos processos de negociação internacional não pode deixar de considerar também a própria dinâmica do arranjo institucional doméstico, que dita os parâmetros da relação entre o Executivo e o Legislativo, fixando suas competências e atribuições. 
A dinâmica desta relação é estabelecida pela Constituição, que fixa o papel de cada um dos poderes, cabendo ao Legislativo um papel de legitimador das decisões do Executivo, na medida em que é o órgão com função institucional de representação dos interesses da sociedade.

Para a autora, haveria uma relação direta entre o nível de cooperação mantido pelos Estados no plano internacional e a dinâmica de interação entre os atores políticos e sociais no âmbito doméstico: Executivo, Legislativo e os grupos de interesse. Em outras palavras, a política externa é, sim, produto do arranjo de interesses entre os grupos domésticos, que se apóiam e se influenciam mutuamente. As chances de cooperação internacional seriam tanto maiores quando um ator com características conciliatórias apoiar o governo.

Martin (idem) analisa o jogo interno da política externa a partir de outra lógica: a idéia de delegação de poderes do Legislativo para o Executivo. Segundo a autora, havendo convergência de posicionamento entre os poderes, o Legislativo tende a delegar a condução da política externa para o Executivo, mas sempre buscando preservar mecanismos que lhe garantam algum nível de influência sobre a política a ser desenvolvida. Esse mecanismo, chamado pela autora de "alarme de incêndio", seria acionado por determinados grupos sociais.

A grande contribuição dessas autoras reside justamente em acrescentar ao debate sobre política externa uma variável doméstica importante: o processo decisório. É justamente a dinâmica interna de tomada de decisão, com valores e interesses múltiplos em disputa, que determinará o produto final da ação externa do Estado e não uma idéia pronta e pré-concebida de interesse nacional.

Com o lançamento da definição de interesse nacional na arena política como objeto de disputa de preferências, o processo de tomada de decisão tende a se complexificar. Para Lima (2000), a internacionalização econômica e a liberalização política colocam em xeque o tradicional processo de formulação da política externa, tendo em vista a dificuldade de definição do interesse nacional em ações com conseqüências distributivas domésticas. E arremata: "as transformações da natureza da política externa, em função da abertura econômica e da liberalização política, 
representam a principal responsável pela relevância causal da política doméstica na sua formação no presente" (idem: 288).

À medida que a política externa é retirada de seu entrincheiramento no âmbito do Poder Executivo e projetada no espaço de disputa política, novos atores passam a interagir no processo de tomada de decisão. Na nossa interpretação, Lima está sugerindo a existência de uma relação entre democratização, liberalização econômica e ampliação do número de atores cuja anuência é necessária para a elaboração de políticas no plano internacional, isto é, uma "poliarquização" do processo decisório.

Esses atores se enquadram no conceito desenvolvido por Tsebelis (1997) de veto player, isto é, de "um ator individual ou coletivo cuja concordância (pela regra da maioria no caso de atores coletivos) é requerida para tomar a decisão de mudar uma política”.

Para González (2005), o processo de liberalização e abertura econômica teve impactos substanciais, tanto em relação aos conteúdos da política externa mexicana, quanto na dinâmica política de sua formulação. A autora aponta três aspectos centrais dessas mudanças.

Primeiro, a adoção de uma estratégia de liberalização econômica ampliou a agenda e modificou a estrutura de prioridades em política externa, colocando em realce os temas econômicos, financeiros e comerciais. A política comercial se transformou no principal instrumento da nova estratégia econômica do governo.

Segundo, a intensificação das interações econômicas com o exterior ampliou o grau de exposição da sociedade mexicana aos acontecimentos mundiais, o que fez crescer o número de atores interessados em influenciar de alguma maneira a política externa. A autora identifica um maior ativismo por parte da sociedade civil e dos atores não governamentais, sobretudo em temas de comércio, meio ambiente e desenvolvimento. A assinatura de acordos comerciais, sobretudo o NAFTA, foi um grande fator de mobilização. O próprio governo criou mecanismos de representação de setores sociais no processo de negociação do Tratado de Livre Comércio da América do Norte.

Terceiro, a liberalização também conduziu a mudanças na dinâmica da política burocrática. O predomínio de temas econômicos na agenda motivou um rearranjo de forças no interior do próprio Executivo, com a ascensão das Secretarias da Fazenda e da Economia e declínio do poder da Secretaria de Relações Exteriores. 
O argumento de González (idem) é compartilhado por vários autores, os quais afirmam que o processo de democratização do México, cuja consolidação ocorreu com a vitória do candidato Vicente Fox, do Partido Ação Nacional (PAN), no ano 2000, produziu um aumento da fragmentação e a complexificação do processo decisório em política externa. A mencionada aproximação entre política doméstica e externa teria impactado no processo de decision-making, hoje aberto à participação de novos atores, a exemplo dos partidos de oposição no Congresso, dos governos estaduais e das organizações não-governamentais (Neto \& Schiavon, 2004).

Adotando como referencial este fenômeno de "poliarquização" do processo decisório em política externa como resultado natural de um contexto de abertura política e econômica, buscamos elucidar em que medida um ator específico, o Congresso, passa a atuar nesta seara, tradicionalmente considerada um domínio reservado do Executivo.

Nem mesmo nos Estados Unidos, onde a literatura sobre o tema se encontra mais avançada, existe um consenso sobre a relevância do Congresso no campo da política externa. As análises variam de um papel irrelevante do Congresso, que assume a condição de mero ratificador das decisões do Executivo, até aquelas que o consideram como o principal ator em política externa, atribuindo ao Executivo um papel secundário. A maior parte dos estudos, no entanto, tende a reconhecer a predominância do Executivo na temática, mas com um peso considerável de atuação do Legislativo (Oliveira, 2003).

O tema, até pouco tempo, vinha recebendo tratamento marginal dos cientistas políticos latino-americanos, em parte, devido ao entendimento bastante sedimentado de que a política externa consistiria em um tema de domínio reservado do Poder Executivo, cabendo ao Legislativo a função de mero ratificador de suas decisões. A política externa seria, portanto, um assunto pouco sensível às atenções dos congressistas.

A literatura sobre o tema aponta que as principais razões que justificariam a pouca expressividade da atuação dos Legislativos dos países latino-americanos em temas de política externa seriam a concentração de poder nas mãos do Presidente da República, a baixa densidade institucional, a falta de expertise dos congressistas em determinados temas e a ausência de incentivos eleitorais, tendo em vista o baixo retorno trazido por mobilizações em temas de política externa (Lima e Santos, 2001; e Oliveira, 2003). 
A idéia de dominância do Executivo na formulação de políticas é bastante arraigada na ciência política latino-americana. O presidencialismo hipertrofiado, no qual o chefe do Poder Executivo assume o controle do processo decisório, relegando a um plano secundário a atuação do Legislativo, é apontado como uma deturpação característica dos sistemas políticos dos países da América Latina.

O conceito de presidencialismo hipertrofiado, embora não tenha sido desenvolvido em um primeiro momento para definir o domínio presidencial no campo da política externa, encontra ressonância também neste tipo de abordagem, já que, no caso da atuação internacional, os sistemas constitucionais atribuem o poder de condução ao Executivo, o que serve de reforço às suas prerrogativas de formulação de política em âmbito doméstico.

Contrariando essa abordagem mais tradicional do papel dos Congressos em temas de política externa, vem ganhando força uma corrente teórica que, na esteira dos trabalhos desenvolvidos por Maria Regina Soares de Lima (2000, 2001), Fabiano dos Santos (2001), Mena (2004), Stuhldreher (2003) e Feliú, Galdino e Oliveira (2007), aponta para uma tendência de ampliação do papel dos Legislativos nacionais dos países latino-americanos, motivada pelo processo de liberalização econômica e pelos seus efeitos distributivos.

Segundo Stuhldreher (2003), no caso da Argentina, o maior interesse do Congresso por assuntos de política externa, em razão da criação do Mercosul e das dificultosas negociações travadas no processo de integração regional, foi acompanhado de uma reforma constitucional que ampliou suas competências para influenciar as decisões internacionais.

Feliú, Galdino e Oliveira (2007), analisando as votações nominais referentes à ratificação dos tratados de livre-comércio na Câmara dos Deputados chilena realizadas após a redemocratização do país, concluíram pela existência de correlação entre os votos dos deputados e a localização de seus partidos no espectro ideológico direita-esquerda. Em diversos casos, houve polarização sobre os temas submetidos à aprovação da Câmara Baixa chilena.

Na mesma linha, Leão (2008, citado por Feliú, 2007) também afirma que, a despeito das limitações institucionais, o Legislativo chileno consegue influenciar o 
processo decisório em política externa, já que o Executivo, por responder a uma base eleitoral mais ampla, tende a incorporar as preferências do legislador mediano em suas decisões.

Para Lima e Santos (2001), o papel de mero ratificador do Congresso deixa de ser eficiente em uma economia globalizada e a tendência é de crescimento da assertividade do Legislativo em matérias de política externa, como reflexo direto do contínuo processo de liberalização comercial, alavancado a partir da última década do século passado.

A abertura econômica intensificou os impactos do comércio exterior, diluindo a fronteira entre a economia doméstica e a economia externa. Os efeitos distributivos da liberação comercial foram sentidos por diversos grupos sociais, de forma que o Legislativo não mais pôde se manter alheio às discussões em matéria de política externa. O custo de uma postura de delegação/abdicação face ao Executivo tornou-se mais elevado (Lima e Santos, 2001). Nas precisas palavras de Maria Regina Soares de Lima (2000):

“A globalização, no sentido amplo da internacionalização da economia e de diversos fenômenos sociais, fomenta a superação da fronteira internolexterno e, conseqüentemente, a internacionalização da agenda doméstica, com a incorporação à esfera da decisão legislativa de questões de política externa, questões que previamente estavam restritas ao Executivo. A integração à economia internacional e a abertura econômica contribuem para a politização da política externa em vista dos impactos distributivos internos da maior participação no comércio internacional, uma vez que em uma economia aberta há ganhos e perdas diferenciados frutos de decisões e negociações internacionais” (Lima, 2000: 287).

O processo de "politização" da política externa traduz um fenômeno através do qual as temáticas externas são inseridas na arena do debate político interno, em que atores concorrem pela imposição de preferências. O Congresso, com atribuições institucionais para o controle das ações do Executivo na seara internacional, torna-se então um ator natural a disputar espaço no processo de tomada de decisão. 
Deve-se atentar, no entanto, para uma distinção realizada por Lima (2000) quanto às políticas capazes de gerar a mobilização dos Congressos nacionais. A autora sustenta que a participação política do Legislativo ocorrerá apenas em temas que tenham impactos diferenciados, positivos ou negativos, sobre os diversos setores da sociedade, isto é, que gerem efeitos distributivos. As demais temáticas, que têm como objetivo a busca por um bem coletivo, tendem a ser conduzidas pelo Executivo, com o apoio do Legislativo, ficando fora da arena de disputa política.

A questão central, a nosso ver, reside no estabelecimento de critérios objetivos que permitam demonstrar essa tendência apontada pela literatura recente, a fim de precisar se essa ampliação na participação dos Legislativos latino-americanos em política externa encontra substrato empírico, ou, ao contrário, apresenta uma matriz predominantemente normativa, apontando para um papel que deveria ser exercido pelos Congressos nacionais.

O presente estudo pretende contribuir para elucidar parte deste debate, analisando os argumentos sustentados por Lima e Santos (2001) à luz do caso mexicano. A escolha do México como objeto de análise para testar a hipótese formulada pelos autores se justifica em razão basicamente de dois fatores: i) o México foi o país latino-americano que empreendeu o processo mais profundo de liberalização comercial, intensificado após a adesão do país ao bloco do NAFTA $^{2}$; ii) o processo de democratização experimentado pelo país a partir do final da década de 80, com o fim da hegemonia do Partido Revolucionário Institucional (PRI), o que provocou uma alteração na relação de forças entre o Executivo e o Legislativo, permitindo avaliar os impactos da estruturação incipiente de um presidencialismo de coalizão sobre a tomada de decisões em política externa.

Esses dois traços da histórica recente mexicana, liberalização econômica, conjugada com abertura política, permitem o enquadramento do país dentro dos requisitos estabelecidos por Lima e Santos como propulsores da participação do Legislativo nacional na política externa, o que valida o teste de hipótese ora proposto. $\mathrm{O}$ problema de pesquisa do qual se parte, portanto, é se o binômio liberalização econômica

\footnotetext{
${ }^{2}$ Conforme salienta Mena (2004), até 2004, o México era o país com o maior número de acordos de livre comércio do mundo.
} 
e democratização política produziu no México o efeito esperado de ampliação do papel do Legislativo em temas de política externa.

Responder a este problema de pesquisa nos leva a outra questão de igual complexidade: a partir de quais parâmetros é possível medir o papel desempenhado pelo Legislativo em política externa? Utilizando como referencial a linha analítica de Henehan (2003), o papel desempenhado pelo Congresso mexicano será medido em função de duas variáveis: a) nível de atividade, que abrange todas as ações realizadas pelo Congresso em política externa e; b) divergência em política externa, tanto no interior das Casas Legislativas e entre os partidos políticos, como em relação ao Executivo ${ }^{3}$.

$\mathrm{Na}$ abordagem proposta neste trabalho, as duas variáveis utilizadas apresentam diagnósticos do papel do Congresso mexicano sob perspectivas distintas. A primeira variável, nível de atividade, relaciona-se ao ativismo congressual, e a segunda variável, nível de divergência, à sua assertividade. Desta forma, a ampliação do papel do Congresso mexicano na seara da política externa será avaliada a partir da conjugação de ativismo e assertividade.

A hipótese sustentada é que o Congresso mexicano, no período analisado, apresentou um crescimento no nível de ativismo, mas a sua assertividade permanece baixa. Nos temas mais latentes, as Casas Legislativas mostraram baixa capacidade de consolidar posições e confrontar o Presidente e, nos momentos em que tentaram agir sozinhas, não obtiveram êxito.

Portanto, o binômio liberalização econômica e democratização política no México produziu um aumento da mobilização no interior do Congresso a respeito de temas de política externa, contudo este ativismo não se traduziu em uma capacidade efetiva de

\footnotetext{
${ }^{3}$ Muito embora utilize as mesmas variáveis de análise de Henehan (2003), nível de atividade e nível de divergência, os indicadores por mim escolhidos para medir tais referencias são distintos. Henehan mede o nível de atividade do Congresso a partir do número de votações nominais (roll-call votes) e o nível de divergência a partir das margens de aprovação dos instrumentos internacionais no Senado norte-americano. Tendo em vista as especificidades do caso mexicano, processo de democratização recente e votações nominais como regra na aprovação de instrumentos internacionais, optei pelo uso de outros indicadores. Assim, o conceito de atividade assume uma dimensão mais ampla, abrangendo todas as ações desenvolvidas pelo Congresso relacionadas a temáticas da área internacional. O nível de divergência também apresenta um espectro de análise maior, encerrando não apenas as divergências no interior das Casas Legislativas expressas nas votações e entre os partidos políticos expressas em suas plataformas eleitorais, como também as divergências entre o Congresso e o Executivo. Conforme será observado ao longo do texto, os debates sobre política externa no México, sobretudo no governo Fox, assumiram um forte viés doméstico, do que decorre a importância da relação entre Executivo e Legislativo como indicador do nível de divergência.
} 
funcionar como contrapeso às ações do Executivo, isto é, em níveis maiores de assertividade.

Dado que as principais faculdades do Congresso em política externa se relacionam ao exercício de um poder de veto ex post sobre as ações do Executivo, julgamos que restringir a análise da mediação do conflito de interesses na área internacional às votações nominais teria como resultado um quadro parcial do papel do Legislativo nacional mexicano. Sendo assim, fizemos também um esforço de levantamento de todas as propostas apresentadas pelos congressistas em temas de política externa, de natureza substantiva ou procedimental; bem como de pedidos de esclarecimentos ou mesmo demonstrações de censura à postura do Executivo, isto é, de quaisquer ações relacionadas à atividade do Congresso mexicano em temas internacionais.

Neste ponto, consideramos de grande valia a observação de Lindsay (1994b) de que os estudos devem evitar uma preocupação exacerbada em responder à pergunta se o Congresso controla ou não a política externa. $\mathrm{O}$ foco da análise deve ser identificar os meios pelos quais o Legislativo consegue impor suas preferências ao Executivo e a eficácia de tais meios.

Embora o foco da presente pesquisa seja o poder ratificador do Congresso exercido por meio das votações, existem meios indiretos de influência do Congresso sobre a política externa, que também serão objeto de análise.

Lindsay (idem), comparando os atores políticos a jogadores de xadrez, sustenta que o Executivo tende a antecipar possíveis reações negativas do Congresso, passíveis de comprometer sua credibilidade no cenário internacional, incorporando desde o início das negociações as preferências dos congressistas. Esta seria uma explicação possível para a ratificação da grande maioria dos atos externos do Executivo pelo Legislativo.

Segundo o autor, a decisão de delegar poder ao Executivo não implica, necessariamente, em uma opção do Congresso de abdicar de suas atribuições. A criação de um processo de tomada de decisão, que incorpore as preferências do Congresso ou que lhe garanta meios de influenciar a implementação de determinada política, apresenta-se como um possível meio de influência indireta. 
Essas inovações procedimentais podem compreender a atribuição de um poder de veto ao Congresso sobre as ações do Executivo, a estipulação de condições a serem observadas, a imposição do dever de elaboração de relatórios periódicos acerca do desenvolvimento das negociações ou a incorporação de novos grupos ao processo de tomada de decisão que partilhem das preferências dos congressistas ${ }^{4}$. Justifica-se, dessarte, a ampliação do material analisado, a fim de conferir maior densidade empírica ao teste de hipótese.

A metodologia utilizada para a pesquisa consiste no levantamento junto às fontes oficiais mexicanas, basicamente o Sistema de Informação Legislativa e os Diários de Debates do Senado e da Câmara dos Deputados, de dados sobre votações em matéria de política externa, abrangendo: a) ratificação de tratados internacionais; b) ratificação de nomeações diplomáticas; c) autorização para a saída do Presidente do território nacional; d) autorização para a saída de tropas do território nacional; e) autorização para o uso de condecorações; f) legislação procedimental para a mudança de atribuições no âmbito das relações internacionais; g) legislação substantiva sobre política externa; h) pontos de acordo e acordos parlamentares sobre temáticas internacionais.

As tabelas elaboradas relevam a taxa de êxito na aprovação de propostas/instrumentos relacionados à área internacional e o volume de atividade do Congresso mexicano nesta seara. No caso específico dos tratados internacionais, foi elaborada uma tabela adicional sobre os instrumentos em cuja votação houve divergência de posição entre os partidos políticos.

A classificação dos tratados em "com efeitos distributivos" e "sem efeitos distributivos" visa testar o argumento de Maria Regina Soares de Lima (2000) de que os temas com efeitos distributivos tendem a gerar maior mobilização dos congressistas, ao passo que nos demais casos a tendência é de cooperação com o Executivo.

Com efeito, a quase totalidade dos tratados em cuja votação houve divisão de posicionamento entre os partidos mexicanos apresenta um componente de efeitos distributivos, embora muitos tratados com possíveis efeitos distributivos tenham sido aprovados por unanimidade.

\footnotetext{
${ }^{4}$ Para uma análise mais detalhada dos meios indiretos de influência do Congresso sobre a política externa, ver Lindsay (2004).
} 
Nosso diagnóstico para este cenário, conforme será apresentado de modo detalhado no capítulo 4, é que a assinatura do Tratado de Livre Comércio da América do Norte (NAFTA) gerou uma abertura tamanha na economia mexicana, que os demais tratados de livre comércio foram percebidos como tendo efeitos menores ou, em alguns casos, como um mecanismo para minimizar a dependência em relação aos Estados Unidos. Apenas em um segundo momento os congressistas passaram a atentar para os reais efeitos dos tratados de liberalização sobre a economia do país, com especial resistência aos tratados sobre investimento estrangeiro (APRI's).

Além das votações propriamente ditas, a variável divergência será aferida a partir dos posicionamentos dos principais partidos mexicanos sobre temas de política externa, revelados por meio das plataformas eleitorais e de material secundário, como entrevistas a meios de comunicação, e também das ações empreendidas pelos congressistas em relação aos temas que geraram maiores atritos com o Executivo.

Como possíveis causas que explicam a atuação pouco assertiva do Congresso mexicano em temas de política externa, apontamos: i) os custos de rejeição de um tratado internacional; ii) o impacto da adesão ao NAFTA, que, ao promover um abrupto processo de abertura econômica, gerou efeitos decrescentes quantos aos acordos comerciais assinados posteriormente; iii) a dificuldade de construção de consensos no interior das Casas Legislativas mexicanas sobre qual deve ser o papel desempenhado pelo Congresso em política externa e sobre a divisão de atribuições entre as Câmara Alta e Baixa; iv) o uso doméstico das atribuições, em detrimento da construção de um política externa de Estado a partir da cooperação entre os poderes. O resultado é a subutilização dos instrumentos constitucionais conferidos pelas reformas realizadas nas duas últimas décadas.

A dissertação está estruturada em quatro capítulos. O primeiro capítulo traz uma revisão bibliográfica sobre os principais autores que tratam da relação entre liberalização, democratização e processo decisório; bem como da relação Executivo-Legislativo em temas de política externa, a fim de situar o trabalho dentro do estado da arte do debate acadêmico e fixar as bases teóricas sobre as quais ele se apóia.

No segundo capítulo, é desenvolvido um panorama sobre a relação entre o Executivo e o Legislativo mexicanos na elaboração de políticas internas e externas, a 
partir da evolução do sistema partidário e do processo de tomada de decisão desde o regime autoritário conduzido pelo PRI até a estruturação do atual sistema multipartidário com governo dividido.

O capítulo três é dedicado à análise empírica. As variáveis atividade congressual e nível de divergência são aferidas a partir de um levantamento das votações no Congresso mexicano sobre temas de política externa e da análise dos demais instrumentos de influência de que dispõem os congressistas. Também serão objeto de consideração o posicionamento dos principais partidos mexicanos na área internacional e os pontos de atrito entre o Executivo e o Legislativo ao longo das legislaturas estudadas.

No capítulo quatro, apresentamos uma proposta de ampliação da agenda de pesquisa, focada nas possíveis causas da baixa assertividade do Congresso mexicano na elaboração da política externa do país.

Na conclusão, a fim de atualizar o debate, face à mudança de governo no México, desenvolvemos breves considerações sobre a postura do Congresso mexicano durante os dois primeiros anos do governo de Felipe Calderón (2007-2008), seguidas das considerações finais. 


\section{CAPÍTULO 1 - O ESTADO DA ARTE DO DEBATE ACADÊMICO \\ SEÇÃO I - DEMOCRATIZAÇÃO, LIBERALIZAÇÃO ECONÔMICA E GEOMETRIA DO PROCESSO DECISÓRIO}

Os impactos da mudança de regime político, notadamente a transição de regimes autoritários para regimes democráticos, sobre a política externa constitui um campo de pesquisa pouco explorado no âmbito da Ciência Política contemporânea. De um lado, a literatura de Ciência Política que se voltou à análise dos processos de democratização experimentados pelos países da América Latina e do leste europeu deixou à margem da discussão os impactos de tais processos sobre a atuação dos países no campo internacional. De outro, a literatura tradicional de relações internacionais, focada na interação entre os Estados enquanto abstrações e não em seu comportamento como atores individuais, também deixou de considerar a conexão entre essas duas variáveis como importante.

De uma maneira geral, os trabalhos existentes exploram a relação entre democratização e o conteúdo substantivo da política externa. Nesta esteira, estão a teoria da paz democrática e os estudos que relacionam processos de democratização e propensão dos países à guerra.

A teoria da paz democrática, de inspiração kantiana, estabelece uma relação natural entre regimes democráticos e comportamentos pacifistas. Segundo esta abordagem, os países democráticos, por raramente considerarem o uso da força, tenderiam a não travar guerras entre si, ao passo que regimes autoritários seriam mais propensos ao conflito em virtude de seu comportamento mais agressivo no cenário internacional.

Em uma segunda fase, a teoria da paz democrática avançou no debate, buscando diferenciar países que estão sofrendo processos de democratização, os quais apresentariam maior tendência a posturas belicosas, e democracias já consolidadas, com uma propensão a posturas mais pacifistas (Mansfield e Snyder, 1997).

No entanto, a relação quase automática entre paz e democracia sustentada por essas teorias sofreu duras críticas de estudos que identificaram relações mais complexas entre essas variáveis (Saraiva, 2003). 
Essas abordagens limitadas deixam de considerar possíveis relações entre os processos de liberalização política e econômica e política externa. Para Hurrell (2003), existem dois possíveis nexos causais entre esses processos. O primeiro deles refere-se aos impactos que o processo de democratização pode gerar sobre o processo de formulação de política externa, alterando a capacidade do Estado de implementá-la de forma coerente. $\mathrm{O}$ segundo seria a relação entre liberalização política e o aumento do número de compromissos internacionais assumidos pelo país, os quais vêm acompanhados de novas estratégias de cooperação internacional.

Esse primeiro nexo causal aborda a dimensão doméstica da política externa. É de se esperar que a democratização altere em alguma medida o processo de tomada de decisão, como decorrência direta do aumento do pluralismo político, com a incorporação de novos atores sociais pelo regime. Essa complexificação do processo decisório tornaria mais difícil a implementação de uma política externa coerente, ao menos nos primeiros anos após a transição de regime.

O segundo nexo causal relaciona os efeitos da liberalização política e econômica com o engajamento dos Estados em organismos internacionais. A participação em instituições econômicas internacionais pode ser utilizada como um mecanismo para aumentar a credibilidade externa do país em relação às reformas liberais adotadas no plano interno.

Kahler (1997) defende a existência de uma relação direta entre o aumento do número de compromissos assumidos pelo país em âmbito internacional e liberalização econômica. No plano político, a adesão a organismos internacionais serviria também para o trancamento e reforço de políticas domésticas (efeitos de locking-in), como na área de direitos humanos (Moravcsik, 2000), ou ainda para aumentar a credibilidade no tocante às reformas democráticas internas.

O caso mexicano de transição democrática não ficou à margem de discussão. Nos Estados Unidos, as análises se centraram no impacto de tal processo sobre a relação do México com o país. A visão dominante era de que a democracia conduziria a uma relação de maior proximidade e harmonia entre os países.

Para Purcell (2004), se, de um lado, a democratização no México tornaria o processo de formulação de política externa mais complexo, como fruto da maior 
participação dos partidos de oposição e do crescente papel do Congresso, de outro, também teria como consequência a melhora de sua imagem internacional, com o aumento da confiança no país, decorrente de uma maior transparência na política interna, e redução das ressalvas em relação ao regime autoritário do PRI.

A idéia subjacente a esses raciocínios é que a democratização do regime político mexicano seria seguida de uma gradual abertura no processo de formulação de política externa, de forma que, pouco a pouco, as decisões deixariam de ser tomadas exclusivamente por um pequeno grupo de expertos, membros de um único partido, ligados às secretarias de Estado, e passariam a contar com a participação de novos atores, governamentais ou não, cujo acesso a tais decisões seria ampliado.

Contudo, a despeito dessa expectativa de um movimento natural de abertura do processo decisório, alertam Cortell \& Peterson (2003) que o processo de democratização ou qualquer outro tipo de conjuntura que abra oportunidade para mudanças políticas não conduz necessariamente a reformas institucionais que afetem a organização da autoridade ou modifiquem a balança de poder entre Executivo e Legislativo nas diversas esferas de política pública. Os autores citam como exemplo desse tipo de cenário a crise da Guerra do Vietnã nos Estados Unidos e o escândalo Watergate, que resultou em reformas no poder do Presidente norte-americano.

Para que uma conjuntura favorável sirva de catalisador para mudanças nesse sentido, é necessária a existência de atores no interior do Executivo e/ou do Congresso interessados em promover essas reformas, em razão de incentivos políticos, eleitorais ou burocráticos, e que tais atores possuam a capacidade institucional necessária para seu êxito. Portanto, a reforma das instituições está condicionada a três fatores: uma conjuntura favorável, estímulo dos agentes para levar a cabo a reforma e capacidade institucional para tanto.

O diagnóstico de González (2007) é que, no caso mexicano, muito embora tenha havido situações críticas capazes de desencadear reformas institucionais no âmbito da política externa, como os conflitos com Cuba e Venezuela e a perda da candidatura do México para o cargo de Secretário Geral da Organização dos Estados Americanos (OEA), os quais despertaram a ação de reformistas, não houve êxito no processo de fortalecimento do papel do Senado em razão da debilidade institucional. Em outras 
palavras, dos três fatores enumerados por Cortell \& Peterson como condições para a mudança, faltou ao Congresso Mexicano capacidade institucional para levar a cabo reformas mais profundas, que acompanhassem o processo de abertura política empreendido pelo país.

A falta de capacidade institucional estaria associada, em um primeiro momento, à resistência do PRI em seus últimos anos de governo (1997-2000) em promover alterações em política externa, apesar das reformas propostas pelos partidos de oposição, e, em um segundo momento, já sob a égide do governo do PAN, à falta de coesão da coalizão governista e à fragmentação partidária no interior do Congresso. Neste último período, a despeito de uma maior inclinação do Executivo em realizar reformas, esses outros fatores travaram o avanço das propostas.

A democratização produziu impactos não somente nas relações entre Executivo e Legislativo em temas de política externa, mas também conduziu a rearranjos entre as diversas agências do governo que competem na condução das ações externas do país. Nos casos dos governos Fox e Calderón, a despeito das diferenças entre os Presidentes, houve um aumento do número de agências governamentais que influenciam no processo de tomada de decisão, como decorrência da incorporação de novos temas na agenda diplomática, tais como direitos humanos e democracia, assim como a ampliação do acesso de atores sociais e econômicos a tais agências (González, 2007).

Para González (idem), três fatores foram determinantes para definir o número de atores burocráticos que participam da política exterior no México e o grau de polarização entre eles: a) a estrutura de prioridades da agenda governamental, que foi alterada pelos processos de democratização e liberalização econômica, levando à incorporação de novos temas e à dispersão de poder entre as agências; b) o grau de coesão da elite governante; c) a configuração institucional, que aumenta os estímulos para que um maior número de atores leve suas demandas às agências. 


\section{SEÇÃO II - RELAÇõeS EXECUTIVO-LEGISLATIVO NO CAMPO DA POLÍTICA EXTERNA}

\section{As COMPetênCias dos Parlamentos em POlítica externa e OS Fatores de DOMINÂNCIA DO EXECUTIVO}

Em um compêndio ${ }^{5}$ editado pela União Interparlamentar sobre a atuação de 56 Parlamentos ao redor do mundo, no capítulo referente à condução da política externa, a conclusão é que o papel dos Legislativos em assuntos internacionais é pequeno, pois, por muito tempo, considerou-se que a diplomacia deveria ser conduzida por chefes de Estado e de Governo. Ademais, os Parlamentos não teriam se mostrado capazes de investir em métodos de escrutínio e controle proporcionais à importância de temas como a paz e as guerras mundiais.

Com efeito, uma análise comparada do papel dos Legislativos nacionais na condução de política externa revela não apenas uma grande variedade de atribuições do ponto de vista legal, como em nível de força e expressividade política. Em países como Bangladesh, Israel, Nova Zelândia, Paquistão e Tailândia, por exemplo, os Parlamentos não têm qualquer atribuição na aprovação de tratados internacionais.

Em outros países, os governos podem ratificar os tratados internacionais sem a aprovação do Parlamento, como ocorre na Austrália. Na Índia, o Parlamento só ratifica o tratado se houver previsão expressa nesse sentido. Na Irlanda, o Parlamento só autoriza o tratado que tiver implicações financeiras. Condicionantes nesse sentido também são observadas na legislação da Espanha e Suécia.

Nos Estados Unidos, o Senado, por maioria de dois terços, pode ratificar os tratados com outros países, contudo, o Presidente pode atravessar a ação do Senado por meio de acordos executivos, que não requerem a anuência da Câmara Alta.

A despeito das diferenças no desenho institucional dos países quanto aos poderes constitucionais conferidos ao Legislativo em matéria de política externa, o consenso é de que o Executivo dispõe de maiores meios, tanto formais, como as prerrogativas constitucionais de condução geral da política externa, nomeação de diplomatas,

\footnotetext{
${ }^{5}$ Parliaments of the World, The Maximilian Press Ltda, 1976, apud Berrueto (2006).
} 
assinatura de tratados e declaração de guerra; quanto informais, decorrentes da própria estrutura do sistema político, que lhe conferem o poder de iniciativa, para influenciar o processo de tomada de decisão em política externa. Já ao Congresso são atribuídos, em geral, mecanismos de controle ex post, como a ratificação de tratados, a aprovação de nomeações diplomáticas, autorização para declarar guerra, bem como a alocação de recursos para a política externa.

Entre as estratégias utilizadas pelo Congresso para colocar em funcionamento o sistema de freios e contrapesos, estão a alocação ou não de recursos financeiros em iniciativas de política externa, a recusa de uma nomeação para cargo diplomático ou a recusa de ratificação de um tratado, além de atos para exortar o governo a que haja de uma determinada forma em relação a um tema de política externa.

Contudo, a influência do Congresso não pode ser medida apenas pelo exercício de suas prerrogativas constitucionais, outras formas de participação, a exemplo da convocação de ministros para prestar esclarecimentos, pedidos de informações, participação em delegações de negociadores, também servem como indicativos da participação ou ao menos do interesse dos congressistas por política externa.

Neste ponto, Lindsay (1994b) destaca que, em alguns casos, os congressistas apresentam razões políticas para não querer o confronto direto com o Executivo. Em primeiro lugar, porque a rejeição de um pleito presidencial pode prejudicar a relação com outros países. Segundo, porque a legislação é normalmente rígida, enquanto a diplomacia requer flexibilidade. Terceiro, porque a ação do Congresso é lenta e muitos temas podem mudar rapidamente. Quarto, porque a legislação pode inclusive criar um efeito perverso: o Executivo segue as orientações do Legislativo para poder lhe atribuir eventuais fracassos. Por fim, em alguns casos, os congressistas acreditam que a legislação pode ser pouco efetiva na prática.

De outro lado, o Executivo também busca utilizar meios para o exercício pleno de suas prerrogativas de condução da política externa, minimizando, assim, a influência do Congresso sobre o processo de tomada de decisão. Entre estes recursos, destacam-se os acordos executivos, que não dependem de aprovação do Legislativo, a requisição de poderes especiais e a realização de lobby junto aos legisladores. 
Essa disputa pelo nicho da política externa tende a ser naturalmente conflituosa, uma vez que é de interesse de ambos os poderes ampliar suas prerrogativas em matéria de relações internacionais. Em muitos casos, tal disputa é levada ao plano da interpretação dos alcances e limites das prerrogativas constitucionais detidas por cada um dos poderes. Enquanto o Executivo tende a uma visão mais ampliativa de seu poder, solapando em alguns casos a necessidade de consulta ao Congresso, o Legislativo desenvolve um esforço de contínuo reforço de seu papel. Em situações de crise, no entanto, esta disputa tende a ceder em prol da busca pelo interesse nacional.

Embora aponte a existência desta disputa entre os poderes, a maior parte da literatura tende a reconhecer certa supremacia do Executivo em matéria de política externa. As razões desta dominância listadas pelos autores são de diversas ordens.

Primeiro, o Presidente teria uma visão melhor de interesse nacional, uma vez que sua base eleitoral é responsiva ao país como um todo, ao passo que os legisladores teriam uma visão mais restrita e responderiam a interesses regionais e locais. Segundo, o Presidente disporia de um staff profissional mais adequado de assessoria e maior acesso às informações. Terceiro, decorrente da própria divisão de atribuições, já que o Presidente, detendo maiores faculdades constitucionais, entre as quais se inclui o poder de iniciativa, usufrui de maior margem de negociação, enquanto o Congresso ficaria limitado a aceitar ou não o tratado. Quarto, o caráter peculiar da diplomacia, que requer liderança, rapidez, expertise e sigilo, atributos próprios do Executivo segundo alguns autores. Quinto, o Presidente da República, por sua própria condição de Chefe de Estado, dispõe de liderança e reconhecimento internacionais. Sexto, o processo decisório no interior do Executivo tende a ser mais célere, pelo número menor de atores envolvidos, ao passo que, no Congresso, o processo de tomada de decisão tende a ser mais demorado e aberto, tendo em vista as dificuldades de se obter consenso entre os legisladores. Sétimo, a proibição de reeleição no México de deputados e senadores, diminuindo sua sensibilidade a temáticas internacionais com efeito de longo prazo e dificultando a formação de um staff permanente de apoio (Velázquez, 2007).

Para Crabb e Holt (1980), além dos poderes constitucionais, o chefe do Executivo possui técnicas informais extraconstitucionais para o manejo da política externa, entre as quais os autores destacam cinco: a) acesso a fontes de informação requeridas para a 
tomada de decisão, tais como departamentos, agências, embaixadas, governos estrangeiros; b) a posição de líder legislativo; c) capacidade de influenciar a opinião pública; d) papel como líder político; e) o poder de envolver o país em relação à determinada ação.

Os autores apontam uma série de exemplos que demonstram a dinâmica entre duas forças contrárias: a determinação do Congresso em desempenhar um papel mais dinâmico em política externa e a existência de diversos problemas dentro e fora dele que limitam sua capacidade de fazê-lo.

\section{AS FALÁCIAS ELEITORAL, TECNOCRATA E DOS ADVERSÁRIOS E OS INCENTIVOS DOS CONGRESSISTAS}

Lindsay (1994a) destaca a existência de três falácias a respeito da relação entre Congresso e política externa: a falácia eleitoral, a falácia tecnocrata e a falácia dos adversários.

A falácia eleitoral parte da premissa de que o pouco interesse ou conhecimento do eleitorado sobre política externa não criaria incentivos para os congressistas atuarem nesta área.

Segundo o autor, as explicações eleitorais falham em dois pontos. Em primeiro lugar, exageram os incentivos que desencorajariam membros a se engajar em questões de política externa e ignoram os incentivos não eleitorais que os motivariam a dedicar-se a tais temas. Em segundo lugar, tais abordagens não compreendem a natureza da relação entre os eleitores e os congressistas: a opinião do eleitorado serve como constrangimento e não como guia para os membros dos legislativos Nacionais.

Alerta Lindsay que, pelo fato dos eleitores não se preocuparem o tempo todo com temas de política externa, os conflitos são pouco freqüentes e a liberdade de atuação dos congressistas é grande. O cálculo de ação leva em conta os custos de contrariar o eleitorado e a importância do tema para o congressista.

As explicações eleitorais apresentariam um quadro pessimista do papel do Congresso, uma vez que, para conseguir a reeleição, os congressistas tenderiam a se 
manter afastados de temas de política externa e, nas poucas ocasiões em que tomariam posição, seria apenas para ganhar votos ou atender a interesses paroquiais.

A falácia tecnocrata, ao seu turno, tende a subestimar a capacidade dos congressistas de lidar com política externa pelo nível de especialização requerido por determinados temas, atribuindo aos membros do Congresso um comportamento mais passivo.

A falácia dos adversários tem como foco a relação conflituosa entre Executivo e Legislativo e deixa de considerar que, em muitos casos, a relação entre os poderes pode ser marcada pela cooperação.

Estas três falácias distorcem a compreensão sobre a relação entre Congresso e política externa e tendem a conduzir a conclusões pessimistas sobre o papel dos congressistas na arena internacional.

Além da influência das falácias descritas sobre a literatura dominante, há autores que apontam a timidez como o principal fator explicativo da baixa atividade do Congresso em política externa.

Esta timidez se deveria a um conjunto de fatores: a) falta de expertise; b) os riscos eleitorais de confrontar o Executivo em política externa seriam superiores aos dos embates sobre temas de âmbito doméstico, face à identificação do Presidente com a idéia de interesse nacional; c) o Presidente disporia de poderes formais em política externa que não possuem equivalente em âmbito interno; d) atribuição do Executivo de iniciar políticas independentemente de aprovação de leis pelo Congresso; e) necessidade de manter determinados assuntos em segredo, enquanto a publicidade é a tônica dos assuntos domésticos; f) dificuldade em fiscalizar a política externa; g) dificuldades em garantir eficiência de programas de política externa; h) a dificuldade em relacionar fins e meios nas ações internacionais.

Contudo, para Lindsay, os congressistas apresentam outras motivações, além da puramente eleitoral, para atuar em temas de política externa. Uma quantidade substancial de atividade legislativa ocorre sem que haja um payoff eleitoral, motivada apenas por preferências pessoais e responsabilidades no interior das Casas do Congresso. Razões pessoais, lealdades partidárias, aspirações no interior da própria Câmara, como ganhar prestígio no interior de um comitê, responsabilidades no interior dos comitês ou ainda o 
ganho de prestígio para ocupar cargos do alto escalão conformam os incentivos não eleitorais para as atividades dos congressistas.

\section{CONTRIBUIÇÕES DO DEBATE NORTE-AMERICANO E O ESTADO DA ARTE DA LITERATURA MEXICANA}

Nos Estados Unidos, existe uma vasta literatura que se propõe a analisar a relação entre o Congresso e o Executivo em matéria de política externa. As análises variam desde a identificação de padrões de cooperação e de conflito entre os poderes, passando por suas atribuições legais e constitucionais, até a identificação dos temas capazes de gerar maior ou menor mobilização por parte dos congressistas.

Em regra, aponta-se a existência de uma divisão de responsabilidades entre o Executivo e o Congresso na área internacional. Os assuntos de interesse nacional costumam gerar padrões de cooperação, ao passo que assuntos secundários são utilizados como instrumento de disputa na arena política interna, em especial para ganhos eleitorais, a partir das críticas à política externa desenvolvida pelo partido do governo.

Para Henehan (2003), a literatura norte-americana que analisa a relação entre Congresso e política externa pode ser dividida em quadro perspectivas. A primeira perspectiva destaca que a emergência dos Estados Unidos como um líder global, associada ao crescimento da importância do sigilo e do acesso à informação, conduziram a um movimento natural de vantagem do Executivo na condução da política externa, em detrimento do declínio do Congresso.

Para a segunda perspectiva, as mudanças no Executivo ao longo do século XX levaram ao movimento contrário, ou seja, à ampliação do papel do Congresso. A terceira perspectiva identifica padrões cíclicos de atividade congressual, comumente associados ao movimento de um pêndulo, o que traduz a noção de momentos de intensa mobilização do Congresso, a qual tende a decrescer progressivamente, até assumir uma postura de aquiescência, retomando posteriormente o ativismo diante do crescimento do Executivo.

A quarta perspectiva, segundo a autora, possui o maior poder explicativo, na medida em que se propõe a identificar certos fatores ou variáveis diretamente relacionadas com alterações no comportamento do Congresso. 
Esta primeira perspectiva, a qual se consolidou como a visão tradicional sobre a condução da política externa, tem sua base normativa em uma decisão da Suprema Corte norte-americana, no caso Estados Unidos vs. Curtiss-Wright, julgado em 1989, no qual o Ministro Sutherland declarou que o presidente possui poderes no âmbito internacional que não possuem correspondência em âmbito interno. Conjugada a essa idéia de um poder formal/constitucional superior do Executivo, está a noção de que os congressistas passam boa parte do seu tempo envolvidos em serviços junto ao seu eleitorado, em problemas paroquiais, em disputas entre as Casas Legislativas, de forma que restaria pouco tempo para formulação de políticas em nível nacional.

Como representante desta perspectiva, Dahl (1950) observa que o aumento dos recursos disponíveis para o Executivo foi acompanhado de uma falta de liderança e responsabilidade no interior do Congresso, o que levou o Executivo a dominar a condução da política externa. Ficou famosa a frase do autor, segundo a qual "o Presidente propõe e o Congresso dispõe" (idem: 58). Na mesma linha, Robinson (1962) destaca que a condução da política externa no século $\mathrm{XX}$ requer informação técnica, dinheiro e velocidade, o que confere vantagens ao Executivo. O único poder relevante para o Congresso nesta seara seria o "poder de controle sobre o dispêndio", que mesmo assim não lhe confere capacidade propositiva ou de iniciativa.

Sundquist (1981) analisa a dominância do Executivo sob outro ângulo. Para o autor, os fatores explicativos da falta de iniciativa do Congresso na área da política externa seriam um efeito perverso do próprio princípio da representação. Os congressistas, por representarem uma pequena parcela do país, não teriam estímulos para assumir a responsabilidade por políticas de âmbito nacional: eles preferem levar o crédito por ações diretas juntos ao seu eleitorado a correr o risco de um fracasso em uma política de âmbito nacional, cujo retorno, no melhor dos casos, é bastante pequeno em termos de cativar seu eleitorado e garantir a reeleição. Desta forma, apenas quando o Presidente se mostrar excessivamente fraco, o Congresso assumiria posição em assuntos nacionais.

\footnotetext{
${ }^{6} \mathrm{O}$ termo se refere ao poder constitucional do Congresso sobre o levantamento e destinação de orçamento, daí sua importância como limite à atuação do Executivo. Seu uso ao longo da história dos Estados Unidos tem sido recorrente, como na aprovação do Ato de Ajuda Financeira de 1974, o qual eliminou a destinação de recursos para o Governo do Vietnã do Sul, contribuindo para o fim da guerra.
} 
Wildavsky (1966), analisando 17 anos de votações (1948-1965), argumenta que os Estados Unidos possuem duas presidências, uma para políticas domésticas e outra para política externa e de defesa, já que as taxas de aprovação no Congresso de iniciativas do Executivo nesta última área são muito mais elevadas. Esta abordagem ficou conhecida como a "teoria das duas presidências".

Hinckley (1994) assume uma posição extrema no debate, ao afirmar que a assertividade do Congresso seria, na verdade, um mito. A autora descarta ambos os argumentos: de um lado, a dominância do Executivo, de outro, a assertividade do Congresso, defendendo um padrão próximo ao "default", em que ambos se mostram inativos e incapazes de encetar novas políticas. Apenas dois casos na história norteamericana seriam ilustrativos de uma real assertividade do Congresso: o debate sobre os Poderes de Guerra em 1973 e o debate sobre a Guerra do Líbano em 1983.

A segunda perspectiva divide-se entre aqueles que atribuem ao Congresso uma dominância sobre o Executivo e outros que consideram o Executivo mais influente em política externa. $\mathrm{O}$ ponto em comum entre as abordagens consiste em reconhecer que o papel do Congresso, seja maior ou menor do que o do Executivo, é significativo em temas internacionais.

Muitos autores dessa perspectiva desenvolvem um trabalho de orientação claramente normativa, destacando os problemas em torno do crescimento do poder do Executivo e exortando o Congresso a ampliar sua influência em política externa, sobretudo em temas relacionados à guerra (Henehan, 2003). O ponto de viragem na relação Executivo-Legislativo é identificado com a década de 1970, mais precisamente com a Guerra do Vietnã.

A partir de 1990, observa-se uma proliferação dos estudos sobre o comportamento do Congresso. O debate avançou no sentido de não apenas responder à questão se o Congresso influencia ou não a política externa, mas descrever "como" e o "quanto".

A terceira perspectiva apresenta modelos explicativos cíclicos ou de pêndulo. Lindsay (1994a) observa que os períodos de aquiescência do Congresso frente ao Executivo constituem a exceção e são sempre seguidos da retomada do ativismo, culminando em um aumento progressivo da assertividade dos congressistas. Falta a esses 
modelos, contudo, uma explicação mais detalhada sobre quais fatores impulsionam os ciclos de mudança no comportamento do Congresso

Este problema foi aparentemente solucionado pelos trabalhos da quarta perspectiva, os quais buscam identificar os fatores que desencadeiam a mobilização dos congressistas. A virtude destas abordagens consiste em oferecer variáveis explicativas passíveis de mensuração.

Rourke (1983) identifica os seguintes fatores que restringem a atividade do Congresso: a) paroquialismo; b) a crença do Congresso na legitimidade do domínio do Executivo; c) desejo pela unidade nacional; d) lealdade dos membros do partido do governo. Os fatores a favor do Executivo seriam o seu poder simbólico, o poder persuasivo do presidente, o apelo partidário e o apoio a projetos dos membros do partido.

Ainda segundo Rourke, algumas variáveis levariam ao ativismo atípico do Congresso, tais como temas que envolvem elevados custos de recursos domésticos, a emergência de políticas inovadoras, o aumento do ativismo de grupos de interesse, o crescimento do interesse do eleitorado sobre temas de política externa, o surgimento de desafios às prerrogativas constitucionais do Congresso, além da fraqueza do Executivo. Sob essas condições, o Congresso tenderia a usar seus meios formais (veto) ou informais (debate público) para impor suas preferências.

Lindsay (1994a) apresenta uma lista dos principais fatores que impulsionaram historicamente a relação entre Executivo e Legislativo na arena internacional: a Guerra do Vietnã, o aumento da diferença nas preferências entre Executivo e Legislativo, as reformas internas do Congresso na década de 1970 e o aumento do ativismo dos grupos de interesse.

Nesta mesma linha, o autor ainda destaca que alguns fatores seriam responsáveis pela manutenção dos níveis de assertividade do Congresso, em oposição ao quadro que vigorou até a Segunda Guerra Mundial, mormente: o aumento do número de temáticas internacionais com as quais os Estados Unidos estão envolvidos, ampliando o espectro de análise do Congresso; o controle sobre orçamento e dispêndio, que substituiu os conselhos e o consentimento em relação aos tratados como o principal meio de influência do Congresso; o crescimento do papel da Câmara dos Deputados, como consequência do aumento da importância do "power of the purse". 
A literatura desta quarta perspectiva lista outros propulsores da atividade dos congressistas na área internacional, como as mudanças no sistema político, incluindo um maior número de grupos; alterações na agenda de política externa; ampliação da importância da mídia; aumento dos tipos, influência e poder dos grupos de interesse; e a mobilização da opinião pública em torno de alguns temas de política externa.

Rosenau (1971) já alertava que, em política externa, a natureza do tema em discussão é fundamental para determinar quem se envolverá na discussão, por quais motivos e qual tipo de interação resultará da resolução do problema. Nesta linha, diversos trabalhos buscaram identificar diferentes comportamentos dos congressistas dependendo do tipo de temática envolvido. Hinckley (1978), por exemplo, destaca a existência de "quatro congressos", conforme a temática discutida seja a guerra, a paz, a defesa ou a ajuda externa.

Rourke (1987), por outro lado, identifica comportamentos diferentes do Congresso de acordo com a sua percepção a respeito dos impactos do tema sobre a política doméstica. De um lado, portanto, estariam os temas de "política externa pura" e, de outro, os temas mistos (intermestic policy), com reflexos sobre a política doméstica, capazes, pois, de gerar maiores mobilizações por parte do Congresso.

No México, os trabalhos não atingiram a diversidade e abrangência do debate norte-americano, contudo, este retrospecto serve de base para lançar luz sobre o que foi produzido até hoje sobre o tema, ainda que sobre o enfoque da experiência norteamericana, e abrir perspectivas para ampliação da agenda de pesquisa.

A literatura mexicana mais tradicional teve como foco de análise a relação entre Congresso e Executivo sob a ótica da política interna, visando identificar quais os fatores responsáveis pela supremacia do Executivo no sistema político do país. Nesta linha, são os trabalhos de Nacif (2004), Casar (2002) e Weldon (1997), os quais apontam o controle da maioria do Congresso e do Executivo por um partido hegemônico, a disciplina partidária e a liderança exercida pelo presidente como os principais fatores de fortalecimento do Executivo no sistema político mexicano durante o domínio do PRI.

No caso específico da política externa, alerta Chabat (1989) que a idéia do Presidente como o grande comandante consiste em uma simplificação da realidade. Mesmo sob o domínio do PRI, o grau e o tipo de liderança exercida pelo chefe do 
Executivo foram bastante variáveis, já que nem todos os presidentes demonstraram interesse em exercer um controle direto sobre a política externa ou em desenvolver uma diplomacia mais personalista. Enquanto presidentes como Echeverria e Salinas desenvolveram diplomacias bastante personalistas e concentraram a tomada de decisão; Portillo, Zedillo e De la Madrid concederam uma maior margem de decisão para os seus chanceleres e para funcionários do alto escalão.

Os estudos que abordam a relação entre o Congresso e o Executivo mexicanos em matéria de política externa são em pequeno número. Tal fato decorre de uma tradição acadêmica muito ligada ao realismo político, que enxerga a política externa como um campo de ação governamental específico, alijado dos processos políticos internos.

Para González (2007), três argumentos servem de sustentação para esta tese: a) a existência de um suposto consenso interno a respeito da postura do país no exterior como expressão de um conjunto de idéias nacionalistas compartilhadas; b) a tese de que o alto grau de centralização na tomada de decisões do presidencialismo mexicano faz com que a política externa seja concentrada nas mãos do Presidente da República ou de seu seleto grupo de funcionários; c) o argumento de que boa parte das ações de política externa não afeta diretamente grupos sociais, o que reduz seus efeitos internos e seu apelo políticoeleitoral.

Dos trabalhos existentes, parte se dedica à análise das atribuições constitucionais do Congresso em política externa, muitas vezes com enfoque jurídico (Chabat, 1986; Cossío, 2003), ou ainda às atividades internacionais desenvolvidas pelo Senado, como a participação na União Interparlamentar (Solana, 2000). A especificidade dessa literatura reside em analisar de maneira isolada o Congresso, sem adentrar no seu jogo político com o Executivo.

Contudo, nos últimos anos, as transformações sofridas pelo país com o processo de democratização, com o consequente surgimento de governos sem maiorias legislativas e com a alternância de partidos no cargo de Presidente da República, fizeram ressurgir o interesse acadêmico em entender de que forma tais alterações em âmbito políticoinstitucional produziram impactos sobre o processo de tomada de decisão em política externa e até mesmo sobre o próprio conteúdo substantivo desta política. 
Neste movimento, Guadalupe González (2005) e Rafael Velázquez (2007, 2008) introduziram uma nova agenda de pesquisa, que busca compreender os padrões de relação entre o Executivo e o Legislativo na arena internacional. Para González, as alterações nas características internas do sistema político mexicano tiveram impacto sobre o processo decisório em política externa. Entre os atores emergentes deste processo, está o Congresso. A autora argumenta, no entanto, que, a despeito do Congresso ter dado alguns sinais de interesse em participar de forma mais ativa na condução da política externa, falta ao Legislativo diversos elementos que lhe permitam ser um contrapeso real e efetivo ao poder do Executivo, sobretudo capacidade institucional.

Velázquez, por sua vez, propõe-se a analisar os padrões de cooperação e conflito entre o Congresso e o Executivo mexicanos durante o governo de Vicente Fox. A conclusão do autor é mais otimista, apontando que, sob o ponto de vista qualitativo, a atuação do Congresso foi de grande expressividade no período de 2000 a 2006, muito embora, quantitativamente, tenha imperado ampla cooperação com as propostas do Executivo.

Os argumentos de González e Velázquez não chegam a se colocar em lados opostos. Ambos observam um movimento do Congresso de tentar buscar maior espaço no processo decisório de formulação de política externa. Entretanto, os instrumentos utilizados nesse esforço têm se mostrado insuficientes para que o Legislativo se constitua em um efetivo contrapeso ao poder do Executivo. Para González, o Congresso tem assumido o papel de caixa de ressonância das demandas sociais em expansão, mas ainda há grande debilidade institucional no momento de canalizar tais demandas por meio de instrumentos de ação concretos e eficazes. 


\section{CAPÍTULO 2 - A EVOLUÇÃO DAS RELAÇÕES ENTRE EXECUTIVO E LEGISLATIVO NO MÉXICO}

Embora o presente capítulo tenha como foco a análise das transformações sofridas pelo sistema político-partidário mexicano com o processo de democratização, entendemos que não seja possível desvencilhar sua compreensão dos eventos antecedentes que desencadearam o processo de abertura econômica do país.

Conforme alerta Pierson (2003), a ordem temporal dos efeitos ou processos tem impacto sobre os resultados observados, razão pela qual não é suficiente a compreensão do valor de uma determinada variável, é necessário também que se precise o momento em que este valor apareceu. Deve-se atentar para o significado da interação entre os efeitos e da dependência dessa interação na seqüência temporal de ocorrência de tais eventos.

A noção de timing é, portanto, sempre relacional. O tempo serve como uma dimensão que une dois processos sociais distintos por vínculos de causalidade (Pierson, idem). No caso em análise, as relações de causalidade são estabelecidas entre a liberalização econômica e a abertura política interna do México, com timings distintos.

Com efeito, o processo de liberalização mexicano começa a tomar forma nos anos 80 do século passado, enquanto os primeiros sinais de desestruturação do regime autoritário são percebidos apenas no final deste período.

Contrariando uma literatura recente (Mansfield, Milner e Rosendorff, 2000), que relaciona tipo de regime político (democracia/autocracia) e postura comercial (liberalismo/protecionismo), apontando para uma tendência das democracias à abertura comercial e das ditaduras ao protecionismo ${ }^{7}$, o caso mexicano ilustra um processo de

\footnotetext{
${ }^{7}$ Mansfield, Milner e Rosendorff propuseram um modelo que enfatiza o papel dos legislativos na elaboração de políticas comerciais em regime democráticos. O ponto central da abordagem é a necessidade do Presidente, em regimes democráticos, de obter a aprovação de uma maioria legislativa para implementar uma determinada política comercial, isto é, existem congressistas eleitos pelo voto popular capazes de impor limitações à ação do Executivo . Este tipo de controle não existe nas autocracias. Nos sistemas parlamentaristas, a ratificação ocorre antes, visto que o Primeiro Ministro deve negociar uma política comercial com a maioria que lhe dá sustentação antes de implementá-la, sob pena de sofrer uma moção de desconfiança. Nos sistemas presidencialistas, alterações da política comercial, em geral, demandam uma ratificação ex post. A hipótese dos autores é que as barreiras comerciais tendem a ser menores entre duas democracias do que entre uma democracia e uma autocracia. A existência de um legislativo que atua como ratificador das políticas comerciais criaria uma ameaça crível, permitindo ao Executivo adotar posturas
} 
abertura econômica conduzido sob a égide de um estado autoritário, fortemente corporativo, liderado pelo Partido Revolucionário Institucional.

Desta forma, a nosso ver, a compreensão das transformações políticas sofridas pelo país, passa, em um primeiro momento, por um contato breve com seu processo de liberalização econômica e com sua respectiva condução política.

\section{SEÇÃO I - ANTECEDENTES}

\section{O PROCESSO DE LIBERALIZAÇÃO ECONÔMICA}

A política comercial mexicana experimentou grandes transformações após os anos 80 do século passado. O abandono de uma política econômica centrada no modelo protecionista de substituição de importações encontra suas raízes na crise enfrentada pelo país neste período, com a queda no preço do petróleo, a crise da dívida externa e a recessão da economia norte-americana. Tais circunstâncias apontavam para a necessidade de uma reestruturação da economia mexicana, na qual mudanças na política comercial e na legislação de investimentos eram consideradas elementos essenciais para a renegociação da dívida externa, e de melhoria nas relações com os seus principais parceiros por meio de acordos de livre comércio (Rosas, 2002).

Foram tomadas medidas progressivas no sentido de remover os obstáculos ao comércio internacional: o país tornou-se membro do Acordo Geral de Tarifas e Comércio (GATT), assinou tratados de livre comércio com um número expressivo de países, incluindo Estados Unidos e União Européia, e foi um dos fundadores da Organização Mundial do Comércio. Ao mesmo tempo, o México assumiu um papel ativo em importantes foros regionais como a Associação Pacífica de Cooperação Econômica (APEC) e a Organização para Cooperação e Desenvolvimento Econômico (OCDE).

Na segunda metade da década de 80 e início dos anos 90, foram implementadas novas reformas, as quais incluíam um programa de privatizações, a facilitação da entrada

mais liberalizantes que de outro modo não ocorreriam. A possibilidade de veto de uma negociação comercial por uma ou por ambas as câmaras legislativas levaria o Executivo a celebrar acordos que impliquem em barreiras tarifárias menores. 
de investimentos diretos externos, a redução das barreiras não-tarifárias, a redução ou eliminação de subsídios e uma postura desregulatória (Cameron e Tomlin, 2000).

O objetivo das reformas era promover a estabilização econômica na área comercial. O processo contemplou a ascensão ao antigo sistema GATT, a qual foi concluída em 1986 (Mena, 2004). A aproximação bilateral com os Estados Unidos mostrou-se como meio de atrair investimentos e dar sustentáculo à política de ampliação das exportações, uma vez que as reformas econômicas não foram suficientes para atingir tais metas.

A superveniência da Área de Livre Comércio da América do Norte (NAFTA) é apontada como a pedra de toque desse amplo processo de liberalização econômica levado a cabo pelo México. A assinatura do NAFTA, em 1993, além de garantir a institucionalização das relações econômicas com o seu principal parceiro econômico, os Estados Unidos (3/4 do fluxo comercial do país), também conferiu maior previsibilidade às ações do governo mexicano, comprometido pelos termos do acordo (Saéz, 2005) ${ }^{8}$.

Como primeira etapa do processo de ajuste aos termos do NAFTA, foram realizadas alterações na legislação do setor de telecomunicações, de regulação de investimentos externos, de propriedade intelectual e concorrência (foi aprovada em 1992 uma Lei Antitruste, que passou a vigorar no ano seguinte).

A despeito da estagnação das negociações da Rodada Uruguai do GATT, o México deu continuidade à negociação de acordos de livre comércio. Além do NAFTA, foram assinados outros 10 tratados com Bolívia, Chile, Costa Rica, G-3 (México, Colômbia e Venezuela), Nicarágua, Triângulo do Norte ( El Salvador, Guatemala e Honduras), União Européia, Associação Européia de Livre Comércio (EFTA) e Israel.

Um aspecto importante emergiu em diversos países da América Latina relacionado à responsabilidade nas negociações comerciais (Rosas, 2002). No México, o Presidente Salinas de Gortari (1988-1994) transferiu toda a responsabilidade de condução

\footnotetext{
${ }^{8}$ O período de 1989 a 1994, que marca a proliferação de inúmeros acordos regionais, é reflexo da descrença no sistema do GATT como a arena mais apta à discussão de demandas comerciais, tendo em vista os impasses enfrentados ao longo do processo de negociação da Rodada Uruguai em virtude do princípio do single undertaking. O governo mexicano, embora comprometido com o multilateralismo, identificou o caráter atrativo de negociar com os Estados Unidos, que já havia firmado acordos comerciais com Israel (1985) e Canadá (1989).
} 
das negociações comerciais da Secretaria de Relações Exteriores (SER) para a Secretaria de Comércio e Desenvolvimento Industrial (SECOFI), atualmente a Secretaria da Economia. No nível governamental, todas as negociações foram conduzidas por um petit comité e foram criados sistemas de consulta para a articulação entre os setores público e privado (Mena, 2004).

\subsection{A CONDUÇÃo POLÍTICA DO PROCESSO DE LIBERALIZAÇÃo ECONÔMICA}

O presidencialismo, com o domínio do Presidente sobre o Estado e o Partido, mostrou-se como um elemento fundamental das primeiras etapas do processo de liberalização econômica. O corporativismo estatal, com a incorporação formal das massas organizadas de empregadores, trabalhadores e grupos populares ao partido e às agências governamentais, garantiu ao PRI o controle do Estado.

A maior alteração política foi observada no mecanismo básico utilizado para sustentar o regime autoritário: uma coalizão, liderada pelo presidente, estruturada a partir de um sistema de barganha entre diversos grupos políticos, que garantiu a estabilidade mexicana do sistema político mexicano por décadas.

Entretanto, para que a liberalização econômica fosse levada a cabo, seria necessária uma alteração neste arranjo. Foi composta uma aliança com novos grupos de poder, levando ao declínio daqueles que constituíram o sustentáculo do governo de Lázaro Cárdenas (1934-1940), notadamente nacionalistas e populistas. Essa nova coalizão seria composta pelas elites econômicas, a presidência (juntamente com a elite estatal) e os remanescentes dos antigos grupos corporativistas e populistas, tendo como eixo de sustentação o compromisso com o desenvolvimento de uma economia de mercado (Poitras e Robinson, 1994) ${ }^{9}$.

A oposição dos principais partidos de esquerda ao programa do presidente Salinas foi recorrente ao longo de seu governo. A mais importante veio do Partido da Revolução Democrática (PRD), originalmente formado a partir da Corrente Democrática do PRI e de diversas organizações políticas menores e partidos de esquerda, como o Partido

\footnotetext{
${ }^{9}$ O PRI recorreu a programas sociais de apelo populista, a exemplo do Programa Nacional da Solidariedade (PRONASOL), mantido durante o governo Salinas de Gortari, a fim de manter sob controle a grande massa da população alijada desse pacto entre grupos de poder do país.
} 
Mexicano Socialista. O PRD se tornou bastante ativo internacionalmente, buscando o apoio da opinião pública externa e também de grupos de intelectuais dos Estados Unidos e Europa contra as políticas de Salinas.

As diferenças entre o PRI e o PRD se manifestaram também em temas da agenda internacional. O PRD buscava se opor às políticas do governo, como a renegociação da dívida externa em 1989, rechaçando a posição de continuar os pagamentos aos credores internacionais e sugerindo a suspensão do pagamento dos juros. O partido também se mostrou contrário a políticas como NAFTA, entendido como subordinação econômica, e propunha um pacto continental que abrangesse não só o comércio, mas também a cooperação econômica e social.

Para Vázquez (2006), apesar da presença de algumas vozes críticas dentro do PRI, o partido se converteu em uma fonte de apoio, mais do que de crítica à política exterior conduzida pelo governo. Outros partidos de oposição, como o PRD, desenvolveram uma vida política ativa como modeladores da opinião pública internacional em relação a assuntos mexicanos. Contudo, sua participação no processo de tomada de decisão se restringiu à atuação no Poder Legislativo, cujo papel na política exterior era relativamente pequeno.

Nas eleições federais de 1998, pela primeira vez, o PRI não conseguiu maioria de dois terços para as reformas constitucionais. Como conseqüência, foi obrigado a negociar com outros partidos políticos, em especial com o PAN, que apoiou iniciativas como a reforma agrária e o NAFTA em troca de reconhecimento político.

Em 1992-1993, uma reforma eleitoral duplicou o número de cadeiras no Senado, de 64 para 128, introduzindo o princípio da minoria e garantindo quatro senadores para cada unidade federativa ao invés de dois. Três dos senadores foram para o PRI e a primeira minoria para o PAN, minimizando a participação dos partidos de esquerda. Ainda assim, o PRD insistia em recuperar o ativismo do México na defesa do direito internacional e sua participação nas organizações internacionais, opondo-se à subordinação da política externa à liberalização econômica.

Neste contexto, o Senado aprovou as iniciativas do governo em política exterior, como o NAFTA. O governo de Salinas de Gortari apresentou o Senado como o iniciador do processo de negociação do acordo comercial, sustentando que a Câmara Alta havia 
recomendado ao Presidente que buscasse um acordo de livre comércio com os Estados Unidos depois de um processo de consultas públicas. Contudo, quando o Presidente sugeriu ao Senado a realização de referida consulta, o processo todo durou apenas um mês, esteve geograficamente concentrado e envolveu cerca de 300 pessoas (Vázquez, idem).

O próprio Salinas e alguns membros de carreira do serviço exterior reconheceram a destacada influência da presidência no processo, de forma que a atuação do Senado se revestiu de um ato de legitimação da decisão. Contudo, uma vez que o Senado validou o ingresso no NAFTA, o governo não deu informações ao Congresso sobre as negociações, o que gerou descontentamento por parte dos partidos de oposição.

A influência do Poder Legislativo na política econômica exterior do México neste período foi limitada pela disciplina partidária no interior do PRI, e pela acomodação de forças PRI-PAN, associada à apropriação do discurso nacional revolucionário, as quais ditaram o comportamento do Congresso.

O PRI e o PAN tiveram um importante papel de apoio e legitimação das políticas do governo. O PRD, ao seu turno, não teve força para influenciar de forma efetiva na política exterior, especialmente no caso do NAFTA, devido à sua baixa representação no Senado e ao pequeno efeito de mobilização da opinião pública.

\section{O PROCESSO DE DEMOCRATIZAÇÃO}

\subsection{DO AUTORITARISMO À DEMOCRACIA PRESIDENCIALISTA SOB GOVERNO DIVIDIDO: A NOVA CONFIGURAÇÃO DO SISTEMA POLÍTICO MEXICANO}

O sistema político mexicano consolidou-se, após a Revolução de 1917, como um regime autoritário, cuja dominação política era assegurada por meio de um sistema de partido hegemônico, com forte viés corporativo, conduzido pelo Partido Revolucionário Institucional (PRI).

Segundo a maior parte dos autores, as duas principais características do regime autoritário mexicano foram a hegemonia de um único partido, o PRI, e a concentração do poder na Presidência da República. Muito embora a Constituição previsse formalmente a 
separação de poderes entre o Executivo e o Legislativo, na prática, o Congresso estava subordinado à autoridade presidencial, que exercia o controle sobre o processo decisório.

Durante a hegemonia do PRI, o processo de tomada de decisão permaneceu centrado na figura do Executivo. As leis, bem como suas alterações, eram definidas nos departamentos executivos, sem que houvesse ingerência do Legislativo. Tal quadro fez com que alguns autores utilizassem a expressão poderes "meta constitucionais" para se referir às atribuições do Presidente da República (Carpizo 1977 e Casar 1996).

Segundo Weldon (1997), três foram os fatores que tornaram possível a dominância do Executivo no México: o governo unificado, que envolvia o controle por um único partido da Presidência da República e da maioria nas duas câmaras do Congresso; a disciplina partidária no interior do PRI; e a liderança exercida pelo Presidente sobre o partido, definindo posições e punindo dissidentes.

Esse cenário começa a sofrer mitigações com a abertura política do regime e a ascensão de partidos de oposição, que paulatinamente passam a ocupar cadeiras nas duas Casas do Legislativo, antes controladas integralmente por membros do PRI. A dominância quase absoluta da Presidência da República passou a ter que lidar com uma nova realidade: a possibilidade de rejeição das propostas por um Legislativo mais heterogêneo e, em alguns casos, com maioria de partidos de oposição.

Para Nacif (2005), com as eleições de 2000, o México completou sua transição do autoritarismo para a democracia, tendo se tornado uma democracia presidencialista operando sob um governo dividido. A divisão do governo transformaria o Congresso em um centro autônomo de tomada de decisão e, como consequiência, na fonte principal das mudanças de política.

Ainda segundo Nacif (idem), com o fim da hegemonia do PRI e das bases estruturantes de seu regime, foram criadas as condições favoráveis à maior atuação do Congresso, já que, do pondo de vista constitucional, o chefe do Executivo mexicano possui a menor quantidade de atribuições, quando comparado aos demais executivos latino-americanos ${ }^{10}$.

\footnotetext{
${ }^{10}$ O Executivo mexicano não dispõe das seguintes faculdades legislativas: exclusividade para iniciar leis em âmbitos específicos, intervenção na elaboração da ordem do dia do Congresso, regulação dos prazos para o relato de iniciativas, veto parcial, fixação da primazia na discussão de determinados assuntos expedição de decretos (Bejar, 2007:27-28).
} 
Com efeito, no período de 1988 a 2000, a legislatura mexicana passou por um notório processo de institucionalização das formas e procedimentos para os trabalhos das duas Câmaras. Como consequiência das alterações produzidas na conformação institucional do Legislativo, observa-se um declínio da capacidade do PRI de determinar o curso dos trabalhos parlamentares.

Nacif (idem) comprovou sua tese a partir da análise das propostas apresentadas à Câmara dos Deputados, que revelaram o impacto do governo dividido sobre o processo de tomada de decisão, sobretudo em dois aspectos: a limitação do papel do presidente na edição de leis e a mudança na dispersão dos recursos entre os partidos representados no Congresso. Para o autor, a ausência de um governo unificado teria como consequiência a cessação da dominância do Executivo ou ao menos a sua mitigação.

\subsection{DO SISTEMA DE PARTIDO HEGEMÔNICO AO MULTIPARTIDARISMO: A NOVA CONFIGURAÇÃO DO SISTEMA PARTIDÁRIO MEXICANO}

Conforme destacado anteriormente, um dos pilares de sustentação do regime autoritário mexicano era a manutenção de um sistema de partido hegemônico, encabeçado pelo PRI, no qual os partidos menores eram tolerados, mas não tinham qualquer condição de ascender ao controle político. Periodicamente, eram realizadas eleições, que conferiam uma aparência de democracia ao regime, mas cujo propósito era apenas atribuir legitimidade à hegemonia do PRI.

Através de um longo e complexo processo, que ganhou corpo a partir das eleições presidenciais de 1988, a hegemonia política do PRI deu lugar a um sistema competitivo composto por três partidos. Tais alterações provocaram reflexos na balança de poder entre o Executivo e Legislativo. Nas eleições intermediárias de 1997, o PRI perdeu a sua maioria na Câmara dos Deputados pela primeira vez desde a sua fundação, em 1929. Em 2000, o candidato da oposição centro-esquerda, Vicente Fox, do PAN, venceu as eleições. Contudo, o PRI continuou a ser a principal força política nas Casas do Congresso mexicano.

Neste processo de transição política, o sistema de partidos sofreu importantes transformações no âmbito nacional, que vão da hegemonia do PRI até uma situação de 
alternância. No plano dos distritos eleitorais locais, passou-se de uma situação de domínio priísta para outra na qual apareciam sete subsistemas diferentes de partidos (1997), para culminar na predominância do PAN sobre o PRI em cerca da metade dos distritos eleitorais. O fim da hegemonia do PRI abriu espaço para a expressão das configurações de interesse local, o que se traduz no surgimento de diversos subsistemas locais de partidos (Méndez, 2003).

De acordo com a análise de Méndez (idem), o ano de 1988 apontou para uma situação de bipartidarismo entre o PRI e a coalizão Frente Democrática Nacional (FDN); em 1991, a recuperação do PRI restaurou o regime de partido hegemônico; em 1994, o sistema evoluiu para um bipartidarismo débil entre PRI e PAN; em 1997, transformou-se em um tripartidarismo incipiente, com a ascensão do PRD, caminhando para a uma tendência de polarização entre PRI e PAN. Este movimento demonstra uma tendência nacional de abandono do sistema de partido hegemônico para a configuração de um sistema multipartidário, que oscila entre o bipartidarismo e o tripartidarismo.

A mudança socioeconômica e as reformas eleitorais ocorridas em 1989 e 1996 são os principais fatores que influenciaram as constantes mudanças sofridas pelo sistema partidário no período de 1991 a 2000. O primeiro fator contribui para um processo de desalinhamento e reacomodação das bases sociais em que se apóia o sistema de partidos, ao passo que o segundo fator tornou possível o surgimento de um sistema multipartidário com características muito específicas (Méndez, 2003:528)

\section{SEÇÃO II - IMPACTOS DA ABERTURA POLÍTICA E ECONÔMICA SOBRE O PROCESSO DECISÓRIO EM POLÍTICA EXTERNA}

\section{GEOMETRIA DO PROCESSO DECISÓRIO E OS NOVOS ATORES}

Neto \& Schiavon (2004) sustentam que a transição democrática no México resultou na multiplicação dos atores que buscam participação no processo decisório nas mais diversas instâncias: no interior do Executivo, com a emergência de outras secretarias, que não apenas a Secretaria de Relações Exteriores; entre os Poderes da 
União, em especial com uma maior mobilização do Senado; entre as esferas de governo, com o fortalecimento do federalismo, ampliando os poderes de Estados e Municípios; com a ascensão de atores não governamentais e também de empresas transnacionais.

Os autores elaboram interessante quadro em que comparam a situação de diversas variáveis políticas do México nos anos de 1982 e 2000, apontando as principais alterações ocorridas, e apresentam um preditor sobre seu impacto sobre a condução da política externa:

Tabela 1 - Instituições e Distribuição de Poder no México, 1982-2000

\begin{tabular}{|c|c|c|c|}
\hline Variável & 1982 & Inicia a erosão & 2000 \\
\hline $\begin{array}{l}\text { Divisão } \\
\text { constitucional de } \\
\text { poderes }\end{array}$ & Presidencial & Sem mudança institucional & Presidencial \\
\hline $\begin{array}{l}\text { Divisão legislativa } \\
\text { de poderes }\end{array}$ & Bicameralismo forte & Sem mudança institucional & Bicameralismo forte \\
\hline $\begin{array}{l}\text { Divisão federal de } \\
\text { poderes }\end{array}$ & Federalismo & Sem mudança institucional & Federalismo \\
\hline $\begin{array}{lr}\text { Atribuições } & \text { em } \\
\text { matéria } & \text { de } \\
\text { condução } & \text { de } \\
\text { política externa } & \end{array}$ & $\begin{array}{l}\text { Executivo (com análises } \\
\text { de política exterior, } \\
\text { ratificação de tratados, } \\
\text { embaixadores e cônsules } \\
\text { pelo Senado e ausências } \\
\text { do território nacional } \\
\text { pelo Congresso) }\end{array}$ & Sem mudança institucional & $\begin{array}{l}\text { Executivo, (com análises de } \\
\text { política exterior, ratificação de } \\
\text { tratados, embaixadores e } \\
\text { cônsules pelo Senado e } \\
\text { ausências do território } \\
\text { nacional pelo Congresso) }\end{array}$ \\
\hline $\begin{array}{l}\text { Fragmentação } \\
\text { partidária }\end{array}$ & $\begin{array}{l}\text { Fragmentação baixa } \\
\text { NEP Deputados: } 1.720 \\
\text { NEP Senadores: } 1.032\end{array}$ & $\begin{array}{l}\text { Aumenta a fragmentação } \\
\text { nas eleições de } 1988\end{array}$ & $\begin{array}{l}\text { Fragmentação média } \\
\text { NEP deputados: } 2.769 \\
\text { NEP Senadores: } 2.786\end{array}$ \\
\hline $\begin{array}{ll}\text { Divisão } & \mathrm{de} \\
\text { propósito entre } & \text { os } \\
\text { poderes } & \end{array}$ & $\begin{array}{l}\text { Governo Unificado } \\
\text { Presidência: PRI } \\
\text { Maioria absoluta nas } \\
\text { câmaras: PRI } \\
\end{array}$ & $\begin{array}{l}\text { PRI perde a Presidência } \\
\text { em } 2000\end{array}$ & $\begin{array}{l}\text { Governo Dividido } \\
\text { Presidência: PAN } \\
\text { Maioria nas Câmaras: nenhum } \\
\text { partido }\end{array}$ \\
\hline $\begin{array}{lr}\text { Divisão } & \text { de } \\
\text { propósito } & \text { entre } \\
\text { câmaras } & \\
\end{array}$ & $\begin{array}{l}\text { Unidade legislativa } \\
\text { PRI Deputados: } 74,8 \% \\
\text { PRI Senadores: } 98,4 \% \\
\end{array}$ & $\begin{array}{l}\text { PRI perde a maioria na } \\
\text { Câmara dos Deputados em } \\
1997 \text { e no Senado em } 2000\end{array}$ & $\begin{array}{l}\text { Divisão Legislativa } \\
\text { PRI Deputados: } 42,2 \% \\
\text { PRI Senadores: } 46,1 \% \\
\end{array}$ \\
\hline $\begin{array}{lr}\text { Divisão } & \text { de } \\
\text { propósito } \quad \text { entre } \\
\text { níveis de governo }\end{array}$ & $\begin{array}{l}\text { Governo unitário } \\
\text { Governadores do PRI: } \\
100 \%\end{array}$ & $\begin{array}{l}\text { PRI perde o primeiro } \\
\text { governo estadual em } 1989 \\
\text { (Baixa Califórnia) }\end{array}$ & $\begin{array}{l}\text { Governo Justaposto } \\
\text { Governadores do PAN: } 25 \%\end{array}$ \\
\hline $\begin{array}{lr}\text { Divisão } & \text { de } \\
\text { propósito } & \text { entre } \\
\text { partidos } & \end{array}$ & $\begin{array}{l}\text { Disciplina total } \\
\text { Índice de disciplina } \\
\text { próximo aos } 100 \%\end{array}$ & $\begin{array}{l}\text { Inicia indisciplina no PRI e } \\
\text { no PAN no sexênio de } \\
\text { Zedillo (reforma eleitoral e } \\
\text { Fobaproa) }\end{array}$ & $\begin{array}{l}\text { Disciplina em declínio } \\
\text { Índice de disciplina: } \\
80-90 \% \text { aprox. }\end{array}$ \\
\hline $\begin{array}{ll}\text { Preditor } & \text { da } \\
\text { condução } & \text { da } \\
\text { política externa } & \end{array}$ & $\begin{array}{l}\text { Total controle do } \\
\text { Executivo (sem } \\
\text { questionamento } \\
\text { Legislativo) }\end{array}$ & & $\begin{array}{l}\text { Controle pelo Executivo (com } \\
\text { grandes questionamentos pelo } \\
\text { Legislativo) }\end{array}$ \\
\hline
\end{tabular}

Fonte: Neto \& Schiavon (2004: 13) 
Para González (2005), as consequências para a política externa das mudanças políticas sofridas pelo México com abertura política e econômica são múltiplas e complexas. Em primeiro lugar, o processo de democratização ampliou os canais de acesso e de representação de grupos de interesses diversos, permitindo que as diversas opiniões da população sobre assuntos internacionais fossem expostas publicamente, isto é, o processo se tornou mais exposto às demandas sociais.

Segundo, em uma situação de governo dividido e de multipartidarismo, a formação de acordos entre o Executivo e o Legislativo se tornou mais complexa, já que não existe um apoio automático às medidas propostas pelo Presidente da República. Esse cenário se torna ainda mais complicado quando são adicionadas variáveis como dispersão e descentralização do poder, resultantes de um fortalecimento do federalismo e da alteração das dinâmicas eleitorais nos distritos.

Terceiro, houve uma modificação na estrutura de incentivos dos diversos atores políticos que tomam parte no processo de condução da política exterior, com forte tendência à politização dos temas da agenda internacional. Em situações de competição, temas de forte conteúdo simbólico, a exemplo do voto sobre o uso da força no Iraque no Conselho de Segurança da ONU, tendem a ser encampados por diferentes atores.

O fato de todos os partidos políticos mexicanos terem incorporado em sua plataforma política das eleições intermediárias de 2003 temas de política externa apresenta-se como um indicador deste fenômeno de "politização" da política externa, em parte motivado pela forte repercussão de certos temas, como a proximidade do início do programa de liberalização agrícola do NAFTA, previsto para 2004.

\section{EvoluÇão das COMPETÊnCIAS CONSTITUCIONAIS EM Matéria de Política EXTERNA}

O sistema de divisão de competências entre Executivo e Legislativo em matéria de política externa é comum à maioria das constituições latino-americanas. Compete ao Executivo a negociação e a assinatura de tratados internacionais, os quais são submetidos posteriormente à ratificação do Poder Legislativo. Em outras palavras, o Legislativo dispõe de um controle ex post sobre os atos do Executivo em matéria de política externa. 
Em que pese a semelhança do desenho institucional mexicano em relação a outros países, a reconstrução da disciplina constitucional do tema nas diversas constituições do país tem por objetivo salientar alguns traços distintivos, que, ao menos do ponto de vista formal, garantem ao Legislativo mexicano maiores recursos para atuação em temas de política externa.

No Decreto Constitucional para a Liberdade da América Mexicana, conhecido como a Constituição de Apatzingán, de 1814, a competência de celebrar tratados de aliança e comércio com as nações estrangeiras pertencia ao Supremo Governo, por intermédio do Poder Executivo (artigo 159), com a aprovação e ratificação do Supremo Congresso (artigo 108).

Na Constituição Federal dos Estados Unidos Mexicanos, de 1824, no artigo 110, inciso XIV, foi atribuída ao Presidente a competência de "dirigir as negociações diplomáticas e celebrar tratados de paz, amizade, aliança, trégua, federação, neutralidade armada, comércio e qualquer outro; mas para realizar ou negar ratificação a qualquer deles, deverá submeter à aprovação do Congresso Geral”"

A Quarta Lei de Bases e Leis Constitucionais da República Mexicana, de 1836, contemplou a organização do Supremo Poder Executivo e, em seu artigo 17, estabelecia as atribuições do Presidente, seguindo a linha da Constituição de 1824 no tocante à direção da política externa ${ }^{12}$.

Na Constituição de $1857^{13}$, novamente é definida a competência do Poder Executivo para dirigir a política exterior, que se traduz na celebração de tratados internacionais ${ }^{14}$.

11 Art. 110 - Las atribuciones del Presidente son lãs que siguen:

(...)

XIV. Dirigir las negociaciones diplomáticas, y celebrar tratados de paz, amistad, alianza, tregua, federación, neutralidad armada, comercio y cualesquiera otros; más para prestar o negar su ratificación a cualquiera de ellos deberá preceder la aprobación del Congreso general.

${ }^{12}$ Art. 17. Son atribuciones del Presidente de la República:

\section{(...)}

XX. Dirigir las negociaciones diplomáticas y celebrar tratados de paz, amistad, alianza, tregua, neutralidad armada, sujetándolos a la aprobación del Congreso antes de la ratificación.”

13 Artículo 85. Las facultades y obligaciones del presidente, son las siguientes:

(...)

X. Dirigir las negociaciones diplomáticas, y celebrar tratados con las potencias estrangeras, sometiéndolos á la ratificación del congreso federal. 
Conforme se pode notar, desde as origens da legislação constitucional mexicana, a divisão de competência entre Legislativo e Executivo em política externa, com o controle a posteriori dos atos deste por aquele, impõe-se como um traço característico.

A Constituição de 1917 é a que se encontra atualmente em vigor no país. Em sua redação original, o inciso $\mathrm{X}$ do art. 89 da Constituição atribuía ao Presidente da República a competência para "dirigir as negociações diplomáticas e celebrar tratados com as potências estrangeiras, submetendo-os à aprovação do Congresso Federal”" ${ }^{\prime 1}$. Este mesmo artigo, no inciso III, estabelecia também ser prerrogativa do Presidente a nomeação de ministros, agentes diplomáticos e cônsules gerais, com a aprovação do Senado.

Os princípios orientadores da condução da política externa não foram incluídos no texto original da Constituição e a atribuição para ratificação dos tratados internacionais foi conferida ao Congresso Federal e não exclusivamente ao Senado ${ }^{16}$. A justificativa para não incorporação dos princípios era de que estes já estariam estampados nos tratados internacionais.

As competências do Senado estavam definidas no artigo 76. O inciso I estabelecia competir à Câmara Alta a análise da política exterior desenvolvida pelo Executivo Federal e a aprovação de tratados internacionais e convenções diplomáticas celebradas pelo Presidente da República. O inciso II do mesmo artigo, com redação ainda em vigor, atribui-lhe o poder de ratificar as nomeações diplomáticas feitas pelo Executivo.

\footnotetext{
14 Importante salientar que, no caso da Constituição de 1857, a organização do Poder Legislativo é do tipo unicameral, isto é, uma única câmara, a Câmara dos Deputados, a qual se atribuiu a prerrogativa de aprovar os tratados, os convênios e convenções diplomáticas celebrados pelo Executivo. Apenas com as reformas de 13 de novembro de 1874, voltou a ser adotado o sistema bicameral, reintegrando-se o Senado. Nestas mesmas reformas, foram divididas as faculdades do Poder Legislativo entre a Câmara dos Deputados e o Senado, outorgando-se a este último a exclusividade na aprovação dos tratados e convenções diplomáticas que celebra o Executivo com as potências estrangeiras

15 Art. 89. Las facultades y obligaciones del presidente son las siguientes:

(...)

X. Dirigir las negociaciones diplomáticas y celebrar tratados con las potencias extranjeras sometiéndolos a la ratificación del Congreso Federal;..."

${ }^{16}$ A redação ambígua da Constituição gerou certa polêmica sobre a exclusividade do Senado na apreciação dos tratados internacionais. Alguns intérpretes viam no dispositivo uma brecha para a defesa da participação da Câmara dos Deputados na ratificação dos tratados. Trata-se, na realidade, de uma referência antiga à estrutura unicameral do Poder Legislativo, a qual foi corrigida com a reforma do texto do artigo em 1988.
} 
Em 6 de dezembro de 1977, foi aprovada uma reforma no inciso I do artigo 76, que ampliou a participação do Senado no processo decisório em política externa. A Constituição de 1917 já havia assegurado sua competência exclusiva de aprovar tratados e convenções diplomáticas, contudo, a nova redação lhe conferiu uma nova função: a de analisar a condução da política externa levada a cabo pelo Executivo. O propósito da reforma foi fortalecer o Senado nesta área, aproximando-se do sistema norte-americano, no qual a Câmara Alta tem a função de dar conselhos ao Presidente, bem como ratificar e autorizar ações de condução da política externa.

A nova redação do artigo 76 da Constituição mexicana gerou certa ambiguidade de interpretação. Se, de um lado, é atribuída ao Senado a faculdade de analisar e aprovar a política externa, de outro, o texto não outorga ao órgão poderes especiais para sancionar, modificar, autorizar ou mesmo formular ações de política externa. A dúvida para os intérpretes reside justamente em quais meios serão utilizados para o exercício desta faculdade, sob pena de se tornar inócua a nova disposição legal.

Para alguns intérpretes do direito, sob uma perspectiva sistêmica, quando o legislador outorga uma faculdade, está implicitamente outorgando os meios inerentes ao seu exercício. Esse raciocínio, embora lógico, encontra resistência no cenário político mexicano, já que implicaria em um aumento expressivo do poder do Senado em uma área tradicionalmente dominada pelo Executivo.

Outros dispositivos constitucionais também são objeto de controvérsia, a exemplo do inciso III do artigo 76, que trata da competência do Senado para autorizar a saída de tropas do território nacional. O texto legal não faz qualquer distinção, o que leva a crer que, qualquer que seja o motivo da saída, deverá ser submetida à aprovação dos senadores. Contudo, durante o Governo Fox, o Executivo sustentou o entendimento de que tal autorização só seria necessária para a saída de tropas na hipótese de guerra.

Divide também os intérpretes o inciso X do artigo 89 da Constituição mexicana, que atribui ao Executivo o encargo de "dirigir a política exterior e celebrar tratados internacionais". Este artigo tem sido invocado de foram recorrente pelo Executivo para defender o entendimento de que caberia apenas a este estabelecer as diretrizes e executar a política externa, enquanto ao Senado restaria um papel marginal de simples aprovação dos tratados. Argumentam em resposta os membros da Câmara Alta que este mesmo 
artigo vincula o chefe do Executivo ao estrito cumprimento dos princípios neles estampados no momento de conduzir a política externa do país.

Em 11 de maio de 1988, uma nova alteração constitucional reformou as disposições do inciso X do artigo 89, conferindo aos princípios de condução da política externa status constitucional. Foi também corrigida a competência para ratificação de tratados, concentrada agora exclusivamente no Senado e não mais no Congresso Federal, em consonância com os artigos 76 e 133 da Carta Magna.

Em 12 de fevereiro de 2007, os artigos 76, inciso I e, o artigo 89, inciso X, foram alvo de mais uma reforma. Quanto a este último, a reforma atribui ao Presidente da República a competência de terminar, denunciar, suspender, modificar, emendar, retirar reservas e formular declarações sobre os tratados e convenções internacionais, submetendo-as à aprovação do Senado. A reforma do inciso I do artigo 76 adiciona às atribuições do Senado a ratificação das decisões do Presidente sobre os pontos acima referidos. As novas redações assumiram a seguinte forma:

Artículo 76. Son facultades exclusivas del Senado:

I. Analizar la política exterior desarrollada por el Ejecutivo Federal con base en los informes anuales que el Presidente de la República y el Secretario del Despacho correspondiente rindan al Congreso.

Además, aprobar los tratados internacionales y convenciones diplomáticas que el Ejecutivo Federal suscriba, así como su decisión de terminar, denunciar, suspender, modificar, enmendar, retirar reservas y formular declaraciones interpretativas sobre los mismos;

II. $a$ XII. ...

Artículo 89. Las facultades y obligaciones del Presidente, son las siguientes:

I. $a I X$.......

$X$. Dirigir la política exterior y celebrar tratados internacionales, así como terminar, denunciar, suspender, modificar, enmendar, retirar reservas y formular declaraciones interpretativas sobre los mismos, sometiéndolos a la aprobación del Senado. En la conducción de tal política, el titular del Poder Ejecutivo observará los siguientes principios normativos: la autodeterminación de los pueblos; la no intervención; la solución pacífica de controversias; la proscripción de la amenaza o el uso de la fuerza en las relaciones internacionales; la igualdad jurídica de los Estados; la cooperación internacional para el desarrollo; y la lucha por la paz y la seguridad internacionales;

XI. $a X X$....... 
As atribuições do Senado em matéria de política externa foram objeto de regulamentação por duas leis específicas: a Lei Geral sobre a Celebração de Tratados Internacionais (1992) e a Lei sobre Celebração de Tratados Internacionais em Matéria Econômica (2004). As leis tiveram por objetivo ampliar o acesso do Senado a informações referentes às diversas etapas do processo de negociação dos tratados internacionais ${ }^{17}$.

As consultas que ocorreram no Senado ao longo das negociações do NAFTA serviram como uma experiência política para uma etapa posterior: a aprovação, em setembro de 2004, da Lei sobre a Aprovação de Tratados em Matéria Econômica, permitindo à Câmara Alta o amplo acesso a consultas antes e após as negociações. A nova lei, de certa forma, demonstrou a força dos legisladores, os quais se consideravam marginalizados das grandes negociações.

Apesar de ser considerada por muitos um grande avanço no papel do Congresso em matéria de política comercial, a aprovação da lei foi bastante conturbada. A lei foi aprovada por unanimidade no Senado em dezembro de 2002, contudo permaneceu durante 16 meses em debate na Câmara dos Deputados. A votação apresentou um forte recorte partidário, os deputados do PRI, PRD, PVEN, PT e Convergência totalizaram 270 votos a favor; os 129 votos contra foram de deputados do PAN, com quatro abstenções. O resultado reflete o desejo da oposição de limitar o poder do presidente do PAN na condução da política comercial, através do fortalecimento dos instrumentos de controle do Poder Legislativo.

O texto apresenta um conteúdo híbrido, com artigos que estabelecem os parâmetros a serem observados na aprovação dos tratados, bem como dispositivos que visam disciplinar o acesso do Poder Legislativo, em especial dos senadores, às negociações de tratados em matéria econômica.

Neste sentido, o artigo $3^{\circ}$ da lei estabelece que um acordo, para ser aprovado, precisa contribuir para a melhora na qualidade de vida dos mexicanos. $\mathrm{O}$ artigo $8^{\circ}$ estabelece a faculdade do Senado de convocar audiências com a presença dos

17 Neste sentido, dispõe o artigo $5^{\circ}$ da Lei de 2004 que, no início de casa período ordinário, o Senado poderá requerer ao Poder Executivo a elaboração de informes sobre o início das negociações formais de um tratado, o qual deverá conter: os motivos da negociação, os benefícios a serem alcançados, bem como um cronograma dos trabalhos. 
negociadores. $\mathrm{O}$ artigo $9^{\circ}$, inciso III, determina que, ao término das negociações, $\mathrm{o}$ Executivo deve fornecer uma lista de todas as concessões feitas pelo México. O artigo 12 prevê consultas com governantes e legisladores.

Analisando a nova lei, sustenta Mena (2006) que esta, se usada de maneira prudente, pode gerar grande credibilidade e legitimidade para a política comercial. Por outro lado, o efeito perverso consistiria na possibilidade de um grupo de legisladores tornar impossível ao Executivo entabular negociações. $\mathrm{O}$ autor aponta como deficiências do novo texto de lei a dificuldade em se definir claramente se um acordo trará melhorias na qualidade de vida da população, tendo em vista as oscilações de retorno no curto e longo prazo; o possível abuso na requisição dos negociadores para prestar esclarecimentos, obstando que estes cumpram seu calendário de negociação; a dificuldade em perceber que algumas concessões podem trazer benefícios ao país; a possibilidade da política comercial ser "capturada" por interesses localistas.

A reforma mais recente em matéria de política externa foi promulgada em 29 de agosto de 2008, tendo por objeto o artigo 88 da Constituição Mexicana, que trata da concessão de autorização para a saída do Presidente do território nacional. Na redação antiga do texto, competia a ambas as Casas Legislativas a aprovação de pedidos de viagem do Executivo. Com as alterações aprovadas, o Presidente mexicano pode se ausentar do país por até sete dias, sem necessidade de autorização específica, desde que informe previamente ao Senado ou à Comissão Permanente os motivos da viagem e também seus resultados. Caso a ausência exceda sete dias, deve ser requerida a permissão do Senado ou da Comissão Permanente.

A nova redação do artigo 88 , fruto da conjugação de iniciativas apresentadas sobre o tema nos últimos anos por membros do PRI, PAN e do PVEM, desagradou parte dos congressistas, que a interpretaram como uma renúncia de uma faculdade importante do Congresso. Para os seus defensores, a reforma busca imprimir maior dinamismo ao exercício das atribuições de Chefe de Estado, atendendo às novas circunstâncias políticas e materiais.

Esta breve evolução da disciplina constitucional das atribuições em matéria de política externa permite apontar as especificidades do desenho institucional mexicano. Em primeiro lugar, a opção do constituinte de concentrar a prerrogativa de aprovação de 
tratados internacionais no Senado, ao invés de exigir a concordância de ambas as Casas Legislativas, a exemplo do que ocorre em outros países latino-americanos, como Brasil e Argentina. Segundo, a existência de mecanismos de controle ex ante dos atos do Executivo, consistentes no exercício da atribuição de analisar a política externa do país e na possibilidade de solicitar informações sobre as negociações em curso.

\section{RELAÇÃo ENTRE O EXECUTIVO E O LEGISLATIVO MEXICANOS NO CAMPO DA POLÍTICA EXTERNA}

Sob a vigência do regime autoritário do PRI, o domínio do Presidente da República no âmbito da política externa foi tradicionalmente maior do que em qualquer outra área de política pública, como resultado de fatores constitucionais e políticos.

No México, a exemplo das demais democracias latino-americanas, a Constituição de 1917 outorga ao Presidente da República um mandato para a condução da política externa, que se traduz nas seguintes atribuições: direção e condução da política externa; nomeação de ministros, agentes diplomáticos e cônsules gerais; celebração de tratados internacionais; uso das forças armadas; declaração de guerra; nomeação do Secretário de Relações Exteriores (incisos II, III, VI, VIII e X da Constituição).

Para González (2005), esse sistema constitucional de distribuição de competências entre o Executivo e o Legislativo teria por fundamento o fato do Presidente da República representar a nação em seu conjunto frente a outros países e organismos internacionais, devendo, portanto, contar com mecanismos institucionais que garantam uma unidade de

propósito nas ações em âmbito internacional. A segunda função seria uma tentativa de blindar a política externa das tensões dos agentes políticos domésticos, na esteira do argumento realista dos temas de "alta política".

A despeito deste desenho institucional de dominância do Executivo, a capacidade formal e real do Congresso de influenciar a política externa varia em função de fatores formais e informais de poder, resultantes do próprio jogo político.

Segundo González (2005), a capacidade do Congresso de exercer um contrapeso ao domínio presidencial em política externa está condicionada aos seguintes fatores: a) distribuição de faculdades constitucionais entre os poderes; b) capacidade técnica e 
profissional do Congresso sobre a matéria, bem como a existência de incentivos para essa profissionalização, a exemplo da possibilidade de reeleição; c) a distribuição de forças partidárias dentro do Congresso e entre os poderes (governo dividido ou governo unificado); d) os incentivos que enfrentam os partidos políticos para ter um maior ativismo nesta seara, como o grau de visibilidade dos assuntos internacionais e seus efeitos distributivos na sociedade.

No México, as atribuições do Legislativo nacional em matéria de política externa abrangem as faculdades do Congresso, exercidas de maneira conjunta pelas duas Casas Legislativas, as quais estão definidas nos artigos 73 e 88 da Constituição Mexicana; e as faculdades exclusivas do Senado, previstas no artigo 76 do mesmo diploma constitucional.

Entre as faculdades do Congresso, podemos $\operatorname{citar}^{18}$ :

a) concessão de autorização ao Executivo para contrair empréstimos no exterior;

b) declarar a guerra, a partir das informações fornecidas pelo Executivo;

${ }^{18}$ Artículo 73. El Congreso tiene facultad:

$$
\text { (...) }
$$

VIII. Para dar bases sobre las cuales el Ejecutivo pueda celebrar empréstitos sobre el crédito de la Nación, para aprobar esos mismos empréstitos y para reconocer y mandar pagar la deuda nacional. Ningún empréstito podrá celebrarse sino para la ejecución de obras que directamente produzcan un incremento en los ingresos públicos, salvo los que se realicen con propósitos de regulación monetaria, las operaciones de conversión y los que se contraten durante alguna emergencia declarada por el Presidente de la República en los términos del artículo 29. Asimismo, aprobar anualmente los montos de endeudamiento que deberán incluirse en la ley de ingresos, que en su caso requiera el gobierno del Distrito Federal y las entidades de su sector público, conforme a las bases de la ley correspondiente. El Ejecutivo Federal informará anualmente al Congreso de la Unión sobre el ejercicio de dicha deuda a cuyo efecto el Jefe del Distrito Federal le hará llegar el informe que sobre el ejercicio de los recursos correspondientes hubiere realizado. El Jefe del Distrito Federal informará igualmente a la Asamblea de Representantes del Distrito Federal, al rendir la cuenta pública;

XII. Para declarar la guerra, en vista de los datos que le presente el Ejecutivo.

XVI. Para dictar leyes sobre nacionalidad, condición jurídica de los extranjeros, ciudadanía, naturalización, colonización, emigración e inmigración y salubridad general de la República.

XX. Para expedir las leyes de organización del Cuerpo Diplomático y del Cuerpo Consular mexicano.

XXIX. Para establecer contribuciones:

10. Sobre el comercio exterior;

XXIX-F. Para expedir leyes tendientes a la promoción de la inversión mexicana, la regulación de la inversión extranjera, la transferencia de tecnología y la generación, difusión y aplicación de los conocimientos científicos y tecnológicos que requiere el desarrollo nacional.

XXIX-M. Para expedir leyes en materia de seguridad nacional, estableciendo los requisitos y límites a las investigaciones correspondientes.

XXX. Para expedir todas las leyes que sean necesarias, a objeto de hacer efectivas las facultades anteriores, y todas las otras concedidas por esta Constitución a los Poderes de la Unión. 
c) estabelecer tarifas sobre o comércio exterior;

d) editar leis para a regulamentação de investimentos estrangeiros;

e) editar leis sobre segurança nacional;

f) concessão de autorização ao Executivo para a promulgação de leis relacionadas com a nacionalidade e outros estatutos migratórios;

g) a concessão de licenças a funcionários mexicanos para aceitar condecorações de outros países.

As demais faculdades estão concentradas no Senado, a quem compete com exclusividade ${ }^{19}$ :

a) analisar a política externa desenvolvida pelo Executivo com base nos informes apresentados pelo Presidente e pelo Secretário de Relações Exteriores;

b) aprovar os tratados internacionais e convenções diplomáticas celebradas pelo Executivo;

c) ratificar as nomeações de agentes diplomáticos, cônsules gerais e de outros funcionários feitas pelo Presidente;

d) autorizar o Presidente a permitir a saída de tropas nacionais fora do país, assim como a passagem de tropas estrangeiras pelo território e águas nacionais;

e) a aprovação de gastos oriundos da representação do México em conferências internacionais;

${ }^{19}$ Artículo 76. Son facultades exclusivas del Senado:

I. Analizar la política exterior desarrollada por el Ejecutivo Federal con base en los informes anuales que el Presidente de la República y el Secretario del Despacho correspondiente rindan al Congreso.

Además, aprobar los tratados internacionales y convenciones diplomáticas que el Ejecutivo Federal suscriba, así como su decisión de terminar, denunciar, suspender, modificar, enmendar, retirar reservas y formular declaraciones interpretativas sobre los mismos;

II. Ratificar los nombramientos que el mismo funcionario haga del Procurador General de la República, Ministros, agentes diplomáticos, cónsules generales, empleados superiores de Hacienda, coroneles y demás jefes superiores del Ejército, Armada y Fuerza Aérea Nacionales, en los términos que la ley disponga;

III. Autorizarlo también para que pueda permitir la salida de tropas nacionales fuera de los límites del País, el paso de tropas extranjeras por el territorio nacional y la estación de escuadras de otra potencia, por más de un mes, en aguas mexicanas.

Artículo 88. El Presidente de la República podrá ausentarse del territorio nacional hasta por siete días, informando previamente de los motivos de la ausencia a la Cámara de Senadores o a la Comisión Permanente en su caso, así como de los resultados de las gestiones realizadas. En ausencias mayores a siete días, se requerirá permiso de la Cámara de Senadores o de la Comisión Permanente. 
f) conceder autorização para que o Presidente se ausente do território nacional por prazo superior a sete dias ${ }^{20}$.

Com a ratificação do Tratado de Roma pelo México em 2005, foi acrescentada uma nova competência ao Senado: aprovar o reconhecimento pelo Executivo da jurisdição do Tribunal Penal Internacional.

Embora o Congresso mexicano, em especial o Senado, disponha de maiores poderes se comparado ao Poder Legislativo de outros países latino-americanos, apresenta igualmente limitações, já que não participa da formação da equipe de governo através da ratificação dos membros de gabinete, nem dispõe de mecanismos parlamentares de aprovação e ratificação de instrumentos internacionais que assegurem a participação de ambas as Casas em todas as fases do processo, desde as negociações até a ratificação, como ocorre em outros Estados.

Alertam Cossio \& Rodriguez (2003), no entanto, que restringir a atuação do Congresso às atribuições do Senado representa uma visão minimalista do processo decisório, já que o Legislativo possui outras funções que afetam diretamente a condução da política externa, a exemplo da concessão de autorização para o Presidente ausentar-se do território nacional, regulação do comercio exterior (sobretudo tarifas) e autorização para declaração de guerra, faculdades partilhadas pelas duas Casas Legislativas.

Seguindo este raciocínio, Mena (2004) aponta que existem quatro maneiras pelas quais o Congresso mexicano influencia a política de comércio exterior: o poder de controle do dispêndio ("power of the purse"), visto que ambas as Câmaras devem aprovar a legislação fiscal e a lei de receitas públicas anual; a influência sobre a autoridade que deve presidir as negociações comerciais; o poder de negociação e lobby em determinadas matérias que afetam o eleitorado e o poder de ratificação.

A Secretaria de Relações Exteriores (SRE) atua como mediadora na relação entre o chefe do Executivo e o Congresso, uma vez que vez possui a atribuição legal de informar aos legisladores sobre qualquer aspecto da política exterior mexicana. O Secretário e qualquer de seus funcionários são obrigados a comparecer quando demandado pelas Casas do Congresso para prestar esclarecimentos. Dentro da sua

${ }^{20}$ Esta faculdade também pode ser exercida pela Comissão Permanente do Congresso. 
estrutura burocrática, compete à Direção Geral de Coordenação Política acompanhar a aprovação de tratados no Senado, as nomeações diplomáticas e as autorizações de saída do território nacional do Presidente da República, além de fornecer as informações solicitadas pelos congressistas a respeito da condução da política externa no país.

O comparecimento do Secretário de Relações Exteriores no Congresso, embora consista em um importante canal de interlocução entre os poderes, ao longo da história mexicana, tem deixado de cumprir seu papel. Em geral, os secretários se dirigem ao Congresso apenas para explicar ações que já foram tomadas e raramente para acordar estratégias a serem desenvolvidas, o que, de certa forma, limita a competência dos legisladores para analisar a política externa.

Apesar da Constituição Mexicana não ter instituído um sistema de controle direto bicameral sobre a condução da política externa, que permita o acompanhamento de todo o processo de aprovação de tratados internacionais, desde as negociações prévias até a sua ratificação, houve certo avanço ao se conferir status constitucional aos princípios que devem nortear a atuação do país no plano internacional, os quais podem ser utilizados como baliza para o controle das ações do Executivo pelo Congresso.

Durante a vigência do governo unificado sob o regime autoritário do PRI, diversos fatores contribuíram para um domínio quase absoluto do Presidente da República na condução da política externa: o controle do Legislativo e do Executivo por um mesmo partido; a disciplina partidária no interior do PRI; a forte liderança do Presidente sobre o partido e seus membros; a unidade ideológica em torno de um projeto nacional; a falta de incentivos no interior do Legislativo para uma participação mais ativa, a qual impediu o desenvolvimento de instrumentos de informação e capacitação técnica no exercício de suas atribuições de análise e supervisão da política externa desenvolvida pelo Executivo.

Como resultado, a atuação do Congresso durante este período revestiu-se de um caráter puramente formal, com a concentração da política externa sob a direção do Executivo. A taxa de aprovação às ações do Executivo, entre as quais se inclui a ratificação de tratados internacionais, nomeação de diplomatas, e autorização de saídas para o exterior, próxima aos $100 \%$, revela o quadro de completa sujeição do Congresso às diretrizes do Executivo. 
A exceção a este quadro se refere ao contexto de negociações do NAFTA, em que o Congresso apresentou algum sinal de inconformismo com a condução unilateral do processo. Houve crítica dos partidos, em especial do $\mathrm{PRD}$, em relação à forma centralizada pela qual o governo Salinas empreendeu as negociações com Canadá e Estados Unidos.

No curso de processo de negociação do tratado, o Secretário do Comércio do México compareceu ao Senado em várias oportunidades para apresentar um relatório sobre o andamento dos trabalhos. Foram realizadas ainda inúmeras reuniões entre os representantes da SECOFI e deputados, com vistas a evitar possíveis manifestações da oposição contra o acordo. Ainda que as ações se revistam de um caráter puramente formal, foram um primeiro passo para um maior envolvimento do Congresso mexicano em assuntos internacionais.

O reconhecimento pelos congressistas da existência de limitações institucionais à sua atuação na política externa fez com que, na década de 90, fossem apresentados diversos projetos de leis que visavam alterar os artigos constitucionais sobre as competências de ambas as Câmaras, os quais serão tratados de forma mais detalhada no próximo capítulo. A Nova Lei dos Tratados, aprovada em 1992 sob um influxo dessas demandas, não trouxe grandes avanços, apesar de ampliar o acesso do Senado à informação sobre as negociações de tratados e curso.

Esse cenário se altera com as eleições de 1997, que marcam o fim do governo unificado, dando início à estruturação de um sistema político multipartidário operando sob governo dividido. De acordo com González (2005), o impacto mais evidente deste cenário de disputa política sobre a geometria do processo decisório em política externa foi a criação de incentivos para uma participação mais assertiva do Congresso nesta seara, notadamente a canalização de demandas por diversos setores afetados pelas ações externas; o uso das atribuições constitucionais, como a permissão de saída para o exterior do Presidente da República, pela oposição como instrumento de negociação de posições com o Executivo; além da vinculação entre os temas de política externa e política interna por intermédio das campanhas eleitorais.

Como primeira manifestação dessa nova postura do Congresso, em 1999, a Câmara dos Deputados, pela primeira vez, apresentou uma votação bastante apertada - 
227 votos a favor e 216 contra - em relação à uma autorização de saída do Presidente para participar de uma reunião do Grupo do Rio, no Brasil.

A tendência de politização da política externa pode ser verificada pela incorporação de temas internacionais na plataforma eleitoral de todos os partidos políticos, reativos à visibilidade que fatos como a Guerra do Iraque e os acontecimentos de 11 de setembro ganharam no país.

Com a vitória da oposição nas eleições presidenciais de 2000, a relação entre o Executivo e Legislativo sofreu novas alterações: são observados os primeiros enfrentamentos entre o Presidente e a Câmara Alta. Em abril de 2002, o Senado, pela primeira vez, negou autorização para que o Presidente viajasse aos Estados Unidos e Canadá.

O propósito da visita era fortalecer a proteção aos mexicanos no exterior e atrair novas fontes de investimento para o país. O Senado argumentou que não possuía informações suficientes sobre os motivos da viagem. As Comissões de Governança e Relações Exteriores, ambas lideradas pelo PRI, votaram a favor da viagem, mas, quando o tema foi submetido ao pleno, os votos contrários da oposição (PRI, PRD e PVEM) asseguraram a rejeição do pedido de autorização. Ao tomar conhecimento da negativa, a estratégia de Vicente Fox foi sensibilizar a população através dos meios de comunicação, responsabilizando a oposição, em especial o PRI, pelo cancelamento da viagem e obstrução de seus objetivos.

Segundo Neto \& Schiavon (2004), depois deste primeiro enfrentamento, o Presidente Fox buscou incorporar as posições dos outros partidos na condução da política exterior, por exemplo, ao não apoiar os Estados Unidos no Conselho de Segurança em relação à uma ação armada contra o Iraque em fevereiro e março de 2003.

Como resultado deste novo jogo político entre Legislativo e Executivo, houve um aumento progressivo no número de propostas apresentadas no Congresso no período de 1997 a 2006 visando promover modificações na divisão de atribuições em matéria de política externa. Entre os temas que suscitaram maior atividade legislativa, estão a aprovação de tratados internacionais, a autorização para o Presidente da República se ausentar do país e a incorporação de novos princípios constitucionais de condução da política externa. 
De um total de 72 iniciativas, apenas duas reformas foram aprovadas. Uma delas foi apresentada pelo Executivo durante o governo Fox, modificando o artigo 21 da Constituição, para estabelecer a atribuição do Senado de aprovar, em cada caso, o reconhecimento da jurisdição da Corte Penal Internacional. A segunda reforma também teve como foco a ampliação das faculdades do Senado, ao estabelecer que, não apenas o ato de ratificação dos tratados internacionais seria submetido à sua deliberação, mas também a denúncia, suspensão ou modificação dos acordos. 


\section{CAPÍTULO 3 - ANÁLISE EMPÍRICA: AS VARIÁVEIS NÍVEL DE ATIVIDADE E NÍVEL DE DIVERGÊNCIA}

\section{Aspectos Teóricos - CONCEITUANDo o COMPORTAMENTO do CONGRESSO}

Antes de adentrar na análise empírica propriamente dita, impõe-se a discussão de problemas teóricos em torno do uso de determinados conceitos para definir o comportamento do Congresso no campo da política externa. O conceito mais comumente utilizado pela literatura para se referir à atuação do Congresso é influência. Influência é um conceito multidimensional de difícil mensuração, podendo abranger o conteúdo ou mesma a aprovação de um determinado projeto de lei, assim como pode se referir à capacidade de mudar a preferência de um ator ou simplesmente de ganhar um voto.

Há autores que apontam a diferença entre exercer influência sobre o conteúdo de um projeto de lei e sobre a sua aprovação. Outros autores, como Rosati (1984), apresentam um conceito mais amplo de influência, analisando a iniciativa, implementação, a formulação (conteúdo) e aprovação de políticas. Em geral, o Executivo dispõe de maiores meios para iniciação e implementação de políticas, embora a atuação do Congresso sobre esses processos não seja de todo descartada. O fato é que, em determinados casos, os fatores se conjugam de tal forma, com a incorporação de grupos de interesse e da própria burocracia no processo, que se torna difícil isolar a influência de cada um dos atores sobre uma determinada iniciativa no campo da política externa .

Outra abordagem também utilizada neste tipo de literatura opta pelo uso dos termos "ganhar" e "perder" para se referir à atuação de cada um dos poderes em relação a um determinado projeto de lei. Assim, se sai vitorioso, isto é, "ganha", aquele que consegue aprovar com êxito suas iniciativas. Um dos problemas de inferir influência a partir da idéia de vitória reside no fenômeno de antecipação de reações descrito por Lindsay (1994).

Para o autor, além de observar se o Presidente obteve ou não êxito na aprovação de uma determinada lei, deve-se também perquirir de que forma este projeto foi moldado, quais condicionantes definiram o seu conteúdo. Desta forma, se o Presidente se antecipa a uma possível rejeição por parte do Congresso e incorpora parte das preferências desse 
ator ao definir o conteúdo de um projeto de lei, o fato dele ser aprovada não representa uma vitória completa do Executivo, já que houve igualmente influência do Legislativo no processo de formulação da política.

Outro problema decorrente deste tipo de análise é transformar a questão da influência dos atores em um jogo de soma zero, no qual ganha só o Congresso ou ganha só o Presidente. A idéia de vitória é mais facilmente aferível sob o ponto de vista do Executivo, na medida em que um ator unitário, o Presidente, expõe a sua preferência. No caso do Congresso, a composição heterogênea das Casas e a diferença de preferências entre os seus membros tornam difícil definir qual é a posição de todo o órgão. Em termos gerais, poder-se-ia definir um veto do Presidente como uma derrota do Congresso e a rejeição de um projeto do Executivo como a vitória do Congresso. Mesmo assim, havendo votos dos congressistas em ambas as posições, é temerário afirmar que houve a derrota do órgão como um todo.

Para Henehan (2003:46), a única maneira de um argumento desta natureza funcionar é especificar quando os interesses institucionais do Congresso estão em jogo e chamar de derrota do Congresso quando uma maioria de seus membros vota contra tais interesses. Contudo, persiste a dificuldade em definir a partir de parâmetros objetivos quais são esses interesses do Congresso.

Ademais, descrever o sucesso do Presidente e do Congresso em obter leis aprovadas não explica o comportamento do ator em si. O Presidente pode conseguir votos sem exercer qualquer influência, ao passo que pode exercer bastante influência e ainda assim perder. Medir a influência preponderante em um determinado caso ajuda a definir quem ganhou ou perdeu, mas pouco explica sobre a maneira como um determinado resultado foi produzido.

Se entendermos a influência como capacidade que tem um ator "A" de fazer com que um ator " $\mathrm{B}$ " faça determinada coisa que de outro modo não faria, então a análise implica em um confronto entre o fato observado e o seu contrafactual. É preciso fazer um teste de controle, a fim de verificar o que o ator " $\mathrm{A}$ " teria feito na ausência do ator " $\mathrm{B}$ " $\mathrm{e}$ assim medir a influência efetiva de um sobre o outro.

$\mathrm{O}$ termo assertividade foi proposto como um conceito alternativo à influência. Para Henehan (idem: 48), trata-se de um conceito de mais fácil mensuração, porque não 
implica em fazer inferências sobre mudar a cabeça de alguém ou sobre o impacto sobre determinada política.

Para Hinckley (1994:8), contudo, “a noção de um Congresso assertivo é, em si, uma assertiva, colocada como um fato, mas ainda não investigada”. A autora vai além no argumento, ao afirmar que a assertividade do Congresso é um mito cultivado por muitos autores, mas que carece de evidências empíricas mais substantivas.

Neste mesmo sentido, Lindsay (1993) alerta que não se pode confundir ativismo com influência, uma vez que o Congresso pode se tornar mais ativista sem obter êxito em alterar o comportamento do Presidente. Para o autor, existem quatro maneiras através das quais o Congresso exerce influência: legislação substantiva, antecipação de reações pelo Presidente, legislação procedimental e meios indiretos.

O presente estudo pretende identificar e explicar ações levadas a cabo pelo Congresso mexicano, em especial pelo Senado, em questões de política externa. A variável dependente, portanto, é o comportamento do Congresso em temas de política externa, o que indica que não se fará referência apenas à legislação de política externa em si, mas também a qualquer ação nesta seara da qual participe o Congresso. O objetivo é identificar o que o Congresso enquanto instituição faz na área de política externa.

O Senado será o foco principal da investigação a respeito do comportamento do Congresso ao longo do período analisado, tendo em vista as prerrogativas constitucionais que lhe são conferidas, o que torna os senadores mais propensos a se envolveram em tais temáticas.

Para determinar quais ações pertencem ao âmbito da política externa, será utilizada como referência a definição de Christopher Hill (2003:3), para quem esta compreende "a soma das relações externas oficiais conduzidas por um ator independente (normalmente um Estado) nas relações internacionais". Desta forma, se votações no Congresso se referirem a um ator fora da fronteira do México ou se referirem a questões com origem internacional, a exemplo de imigração, tarifas, defesa nacional, serão incluídas na análise.

Seguindo o escorço teórico de Henehan (2003), serão analisados dois aspectos do comportamento do Congresso: atividade em política externa e divergência em política externa. A primeira questão, portanto, a ser respondida é: o que o Congresso faz? Se o 
Congresso não faz política externa propriamente dita, ele desenvolve uma série de atividades que lhe são correlatas, relacionadas à investigação, acompanhamento e implementação.

A atividade do Congresso pode também servir como um importante indicativo da concepção de seus membros a respeito do papel das Casas na política externa. Se a crença é de que seu papel é marginal nesta temática, a tendência é de uma atividade mais tímida, ainda que haja divergências em relação ao Executivo. A atividade congressual é assim definida como todas as ações do Congresso mexicano, em especial do Senado, desenvolvidas com o intuito de influenciar ou moldar uma política em âmbito internacional.

Neste ponto, merece destaque a distinção feita por Lindsay (1994a) entre a tentativa de influenciar e o sucesso desta influência. Existem diversas maneiras pelas quais os Congressos podem demonstrar ativismo em política externa: a) podem ser consultados por membros do Executivo; b) encontrar-se com membros do Congresso e com lobistas; c) falar com o seu eleitorado, com a imprensa ou convocar audiências públicas; d) viajar para o exterior e eventualmente participar de negociações internacionais; e) apresentar projetos de lei, exortações ou pontos de acordo; f) exercer seu direito de voto no tocante à aprovação de tratados ou projetos de lei sobre política externa; g) discutir nos comitês.

Limitar qualquer discussão sobre ativismo congressual em política externa à legislação, seja ela substantiva ou procedimental, perde uma boa parte do que o Congresso realmente faz. As dificuldades de se aprovar legislação, associada à velocidade em que ocorrem os eventos internacionais, encorajam os congressistas a utilizar meios não legislativos para influenciar políticas (Lindsay, idem: 138).

Ativismo não é sinônimo, contudo, de maior influência: muitas leis acabam adormecidas em comitês, relatórios permanecem não lidos e discursos são rapidamente esquecidos.

Neste ponto, pretendemos traçar uma diferença entre ativismo, definido pelo volume e diversidade de atividades desenvolvidas pelos congressistas em matéria de política externa, e assertividade, entendida, para as finalidades deste estudo, como a capacidade do Congresso de converter suas preferências em ações efetivas de política 
externa, seja rejeitando iniciativas que contrariem seus interesses, seja impondo mudanças de comportamento ao Executivo.

\section{INSTRUMENTOS DE INFLUÊNCIA DO CONGRESSO: PODER DE RATIFICAÇÃO, LEGISLAÇÃO SUBSTANTIVA, LEGISLAÇÃO PROCEDIMENTAL, O PODER DE CONTROLE SOBRE O DISPÊNDIO E OS MEIOS INDIRETOS}

A proposta desta pesquisa de mensurar a atividade do Congresso mexicano em política externa, em especial do Senado, pressupõe, portanto, o conhecimento dos instrumentos à disposição dos congressistas para atuar na área internacional: o poder de ratificação, a competência legislativa, do ponto de vista substantivo e procedimental, o poder de controle sobre o dispêndio e os meios indiretos de influência.

$\mathrm{O}$ instrumento mais evidente de que dispõe o Congresso na seara da política externa é o seu poder de veto, que abrange as faculdades de ratificação dos tratados internacionais, das nomeações diplomáticas, de autorização de saída de tropas e do Presidente do território nacional e do uso de condecorações. Utiliza-se a terminologia

poder de veto, pois, em tais hipóteses, o Congresso não dispõe de capacidade propositiva, limitando-se a chancelar ou rechaçar uma iniciativa do Executivo.

Das faculdades abrangidas pelo poder de veto, a ratificação de tratados internacionais apresenta peculiaridades, pois, além de envolver a dinâmica entre Executivo e Legislativo, coloca em questão os compromissos assumidos pelo país em âmbito internacional. Entre os extremos de aceitar ou rejeitar um tratado, o Senado, no caso mexicano, tem a opção de alterá-lo sob a forma de reservas ou entendimentos.

Para Lindsay (1994a), a habilidade do Congresso de rejeitar um tratado direta ou indiretamente condiciona o Executivo a antecipar possíveis reações dos congressistas. Presidentes com grande oposição no Senado teriam incentivos para negociar tratados que reflitam os interesses dos congressistas.

Crabb e Holt (1980), à luz da experiência norte-americana, apresentam uma explicação interessante sobre a relação entre duas das competências do Senado em matéria de política externa: a aprovação de tratados internacionais e a ratificação de nomeações diplomáticas. A idéia subjacente é a de que o Senado, ao aprovar as 
nomeações diplomáticas, desempenharia um papel importante na indicação dos agentes que participam das negociações dos tratados internacionais, podendo exercer alguma influência sobre elas. Esta ligação inicial se rompeu e o Senado assumiu o papel de mero ratificador das indicações do Executivo.

No caso da competência para autorizar a saída do Presidente do território nacional, a atuação do Congresso mexicano, sobretudo durante o Governo de Vicente Fox (2000-2006), demonstrou que seu uso pode apresentar um forte viés doméstico. A rejeição de um pedido de saída do Executivo pode servir para ampliar a pressão interna contra o Presidente ou demonstrar reprovação em relação à condução da política externa do país.

Além de ratificar as ações do Executivo, outro instrumento de que dispõe o Congresso para atuar em política externa é a aprovação de leis que versem sobre matéria internacional, sejam elas substantivas ou adjetivas.

As dificuldades enfrentadas pelos membros do Congresso para transformar suas preferências em política externa em legislação são comumente atribuídas às vantagens inerentes da Presidência, às divisões institucionais e partidárias no interior das Casas e aos cálculos eleitorais de seus membros.

A legislação substantiva apresenta três desvantagens. A primeira é que alguns aspectos da política externa estão além do alcance da legislação, uma vez que, do ponto de vista constitucional, a autoridade para negociar tratados está concentrada no Presidente e não do Congresso. A segunda desvantagem reside na dificuldade de se aprovar legislação pela falta de consenso nas Casas Legislativas e pelo poder de veto do Presidente. Muitos congressistas temem os custos eleitorais de contrariar o Executivo, já que a condução da política externa é usualmente associada a uma presidência forte.

A terceira desvantagem é que a lei é limitada como instrumento de política externa. Eventos podem tornar a legislação obsoleta do dia para a noite e muitos temas não apresentam efeitos distributivos. Além disso, a legislação pode resultar em um efeito perverso, transferindo a responsabilidade de uma política do Executivo para o Legislativo.

Para Lindsay (idem), mais do que o desejo de converter suas preferências em lei, o debate sobre legislação substantiva pode ser utilizado como um instrumento para 
moldar políticas e extrair concessões do Executivo. O Legislativo revela suas preferências para forçar uma antecipação de reação por parte do Executivo e fazê-lo alterar uma política. Contudo, a efetividade de tal instrumento decorre da capacidade de impor uma ameaça crível ao Executivo, bem como da intensidade das preferências no interior da administração.

O Congresso também pode utilizar uma série de alterações procedimentais para influenciar a política externa, criando novas agências, adicionando ou removendo participantes do processo de tomada de decisão, submetendo as decisões da administração ao veto do Legislativo, elaborando regras às quais devem se submeter os programas de política externa e impondo deveres de comunicação à burocracia.

Os deveres de comunicação abrangem as notificações aos membros das agências governamentais, para que informem ao Congresso quando adotam determinadas ações, e a elaboração de relatórios periódicos ou pontuais. Os requerimentos servem para aumentar as informações dos congressistas sobre temas de política externa, colocar determinados temas na agenda do Executivo, estimular a troca de informações entre agências, forçar a administração a tomar posição em relação a um tema ou expor discordâncias no interior da burocracia (Lindsay, 1994a: 108-109).

Fatores como a intensidade das preferências do Executivo e o custo de monitoramento das ações e de punir desvios de conduta determinam a efetividade das alterações procedimentais aprovadas pelo Congresso.

O terceiro recurso de que dispõe o Congresso é o poder de autorizar e determinar despesas, isto é, o controle sobre as leis orçamentárias e fiscais, designado pela literatura norte-americana de "power of the purse". A experiência dos Estados Unidos demonstra que o Congresso pode utilizar esta prerrogativa para proteger seu poder em relação aos tratados e garantir que o país cumpra as obrigações assumidas em âmbito internacional, assim como para bloquear a implementação de um tratado recém-assinado. Para Crabb e Holt (idem), o controle orçamentário e fiscal serve como um limitador da atividade do Executivo, não no sentido de indicar quais ações devem ser tomadas, mas sim aquilo que não pode ser feito.

Os congressistas podem ainda influenciar a política externa através de meios não legislativos: diplomacia congressista, que abrange a participação em negociações 
internacionais; viagens internacionais e contato com representantes de outros países; consultas entre Executivo e Legislativo e mobilização da opinião pública.

\section{SEÇÃO I - A VARIÁVEL NÍVEL DE ATIVIDADE DO CONGRESSO - DIAGNÓSTICO DO ATIVISMO}

A fim de mensurar a atividade do Congresso mexicano em política externa durante o período de 1994 a 2006, que abrange os governos dos Presidentes Ernesto Zedillo (1994-2000) e Vicente Fox (2000-2006), foi realizado um levantamento, por legislatura, das iniciativas substantivas e procedimentais em matéria de política externa submetidas à votação, bem como do número de pontos de acordo ("puntos de acuerdo"), isto é, de entendimentos dos congressistas sobre temáticas internacionais apresentados em plenário, e dos acordos parlamentares.

A legislação substantiva analisada compreende todas as iniciativas que tenham por conteúdo temas relacionados à área internacional. A legislação procedimental se refere às propostas submetidas à votação que visam alterar a divisão de atribuições entre o Congresso e o Executivo no que concerne à condução da política externa ou qualquer outro aspecto procedimental desta seara.

Os pontos de acordo, seguindo a nomenclatura utilizada no Sistema de Informação Legislativa da Secretaria de Governo do México, foram divididos em: a) exortações e censuras ao Executivo; b) pedidos de informação ao Executivo; c) pedidos de comparecimento; d) pedidos de criação de comissões ou grupos de trabalho; e) exortações ou pedidos ao Legislativo; f) outros. A mesma divisão foi adotada em relação aos acordos parlamentares sobre política externa, os quais se distinguem dos pontos de acordo apenas em relação à sua origem, já que estes são fruto de arranjos entre os grupos parlamentares do Congresso, ao passo que aqueles são de iniciativa dos congressistas individualmente.

As informações referentes às Legislaturas LVII, LVIII e LIX (1997-2006) foram extraídas do Sistema de Informação Legislativa da Secretaria de Governo do México ${ }^{21}$,

\footnotetext{
${ }^{21} \mathrm{O}$ endereço eletrônico em que estão disponíveis os dados utilizados é: http://sil.gobernacion.gob.mx.
} 
cujo banco de dados abrange a atividade legislativa a partir da LVII Legislatura. No caso da Legislatura LVI (1994-1997), os dados foram obtidos a partir de um minucioso trabalho de pesquisa junto ao diário de debates da Câmara dos Deputados e do Senado mexicanos $^{22}$, que permitiu o levantamento dos temas de política externa submetidos à votação neste período.

As tabelas de dados, elaboradas por legislatura, apresentam o número total de iniciativas/pontos de acordos submetidos à votação, o número de aprovados, o número de pendentes e o número de rejeitados. A porcentagem de aprovação, calculada ao final, expressa as taxas de êxito do Legislativo em construir consensos sobre temas de política externa.

Para o cálculo da taxa de aprovação, foram excluídas as iniciativas/pontos de acordo pendentes e os rejeitados, uma vez que o fato destes permanecerem durante longo período tramitando pelas comissões, sem serem submetidos à votação, representa, em muitos casos, uma forma de rejeição indireta, que evita o confronto e a exposição das votações.

\section{BREVES CONSIDERAÇÕES SOBRE O PROCESSO LEGISLATIVO MEXICANO}

O artigo 71 da Constituição Mexicana prevê que somente o Presidente da República, os deputados, senadores e as legislaturas dos Estados podem apresentar, perante o Congresso da União, iniciativas de leis e decretos, os quais serão submetidos à revisão, estudo e relato da comissão correspondente de acordo com a matéria tratada.

O artigo 72 define as etapas do processo legislativo. A Câmara em que se apresenta o projeto em primeira instância é designada de Câmara de Origem, ficando a outra como Câmara Revisora.

Na Câmara de Origem, o projeto ou decreto será encaminhado à comissão correspondente $^{23}$, de acordo com a matéria tratada, para ser relatado (elaboração de

\footnotetext{
${ }^{22}$ Os diários de debates de todas as legislaturas estão disponíveis no endereço eletrônico do Senado mexicano http://www.senado.gob.mx. Ao longo do processo de pesquisa, foram acessados, dia a dia, os diários referentes aos anos de 1994 a 1997, a fim de se obter os dados sobre temas de política externa submetidos à votação.

${ }^{23}$ A existência de comissões nas Câmaras do Poder Legislativo mexicano remonta ao Primeiro Congresso de Chilpancingi, em 1813. As comissões compõem a estrutura básica de divisão dos trabalhos no interior
} 
ditame). Os ditames de sua competência são formulados por cada comissão dentro de 5 dias seguintes à data de recebimento. A apresentação do ditame conterá a exposição de motivos em que se funda, assim como as proposições que podem ser submetidas à votação (artigo 87 do Regulamento para o Governo Interior do Congresso Geral dos Estados Unidos Mexicanos).

Entre as atribuições das comissões ordinárias estabelecidas pela Lei Orgânica do Congresso, está o poder de solicitar, por intermédio de seu presidente, os arquivos oficiais da nação, informações e cópias de documentos de que necessitem e de convocar funcionários para prestar esclarecimentos sobre os temas em discussão.

Uma vez analisadas as informações fornecidas, as comissões emitem um ditame, que deverá ser aprovado pela maioria de seus membros. Na hipótese de empate, o voto de minerva compete ao presidente da comissão. Os ditames apresentam caráter meramente preparatório, de forma que todas as resoluções estão sujeitas à discussão e aprovação pelo pleno da Casa Legislativa.

Elaborado o ditame e aprovado pela maioria dos membros da comissão, o projeto é encaminhado ao plenário da Câmara de Origem, para aprovação. O projeto é apresentado em ditame de primeira e segunda leitura, podendo ser submetido à discussão, caso os congressistas entendam que algum ponto não está claro. Na hipótese do projeto não ser aprovado, é realizada votação econômica para definir se ele retorna à comissão de origem. Se a votação for em sentido negativo, o projeto é tido como rejeitado. O mesmo procedimento ocorre no interior da Câmara Revisora.

Aprovado pelas duas Câmaras, o projeto é encaminhado ao Executivo, para sanção. Quando o Executivo rechaça total ou parcialmente um projeto, deverá devolvê-lo à Câmara de Origem, para ser discutido novamente ou para sua confirmação. $O$ veto do

\footnotetext{
dos parlamentos, variando em papel e força política. No caso mexicano, a Lei Orgânica do Congresso Geral, de 1994, fixa a existência de 26 comissões ordinárias no Senado, cuja função básica consiste na análise e discussão de propostas, realização de estudos e formulação de ditames, os quais são submetidos à análise do Pleno da Câmara dos Deputados ou do Senado. São elas: Administração; Agricultura; Pecuária; Silvicultura e Recursos Hidráulicos; Biblioteca, Informática e Assuntos Editoriais; Comercio e Fomento Industrial; Comunicações e Transportes; Defesa Nacional; Direitos Humanos; Desenvolvimento Social; Distrito Federal; Educação, Cultura e Ciência e Tecnologia; Energia, Minas e Indústria Paraestatal; Estudos Legislativos; Governança; Fazenda e Crédito Público; Justiça; Marinha; da Medalha Belisario Dominguez; Pesca; Pontos Constitucionais; Reforma Agrária; Regulamentos e Práticas Parlamentares; Relações Exteriores; Saúde; Trabalho e Previdência Social; Turismo e Jurisdicional.
} 
Executivo poderá ser derrubado por $2 / 3$ do número total de votos de ambas as Casas Legislativas.

De qualquer maneira, as modificações feitas pelo Executivo serão encaminhadas novamente à comissão que relatou o projeto, para que realize novo ditame, o qual tratará particularmente dos artigos modificados. Este ditame será submetido à nova discussão e confirmação pelas Casas do Congresso (artigos 136 e 137 do Regulamento para o Governo Interior do Congresso Geral dos Estados Unidos Mexicanos).

Caso o projeto seja rejeitado pela Câmara Revisora, deverá ser devolvido à Câmara de Origem. Se for aprovado por maioria absoluta, será enviado à Câmara Revisora para reconsideração e, se aprovado também por maior absoluta nesta Casa, passa ao Executivo para sanção.

As votações de leis e decretos são nominais, tanto para a aprovação do projeto integral, como para cada um dos artigos que o integram.

Os quadros abaixo ilustram a composição da Câmara dos Deputados e do Senado mexicano em quatro períodos distintos: 1994-1997 e 1997-2000, que abrangem o governo Zedillo; e 2000-2003 e 2003-2006, que correspondem ao governo Fox. A combinação do número de cadeiras ocupadas por cada partido permite estruturar as diversas possibilidades de coalizões vitoriosas, a favor ou contra o governo, segundo os critérios de votação previstos na Constituição mexicana (unanimidade, maioria absoluta e maioria qualificada).

$\underline{\text { Tabela } 2 \text { - Câmara dos Deputados - } 1^{\circ} \text { Triênio do Governo Zedillo (1994-1997) }}$

\begin{tabular}{|l|l|l|}
\hline \multicolumn{1}{|c|}{ Câmara dos Deputados } & \multicolumn{1}{|c|}{ Tipo de coalizão } & \multicolumn{1}{c|}{ Partidos } \\
\hline $\begin{array}{l}\text { Bloqueio com o PRI } \\
\text { (em apoio ao governo) }\end{array}$ & Unanimidade $=500$ votos & $\begin{array}{l}\text { PRI+PAN+PRD+PT } \\
300+119+71+10=500\end{array}$ \\
\hline & De maioria qualificada $=334$ & $\begin{array}{l}\text { PRI +PAN } \\
300+119=419\end{array}$ \\
& votos & PRI +PAN+PT \\
& & PRI+PRD \\
& & $300+71=371$ \\
& & \\
\hline
\end{tabular}




\begin{tabular}{|c|c|c|}
\hline & & $\begin{array}{l}\text { PRI+PRD+PT } \\
300+71+10=481\end{array}$ \\
\hline & $\begin{array}{l}\text { De maioria absoluta }=251 \\
\text { votos }\end{array}$ & $\begin{array}{l}\text { PRI }-300 \\
\text { PRI +PAN } \\
300+119=419 \\
\text { PRI +PAN+PT } \\
300+119+10=429 \\
\text { PRI+PRD } \\
300+71=371 \\
\text { PRI+PRD+PT } \\
300+71+10=481\end{array}$ \\
\hline $\begin{array}{l}\text { Bloqueio da oposição } \\
\text { (contra o governo) }\end{array}$ & $\begin{array}{l}\text { De maioria absoluta }=251 \\
\text { votos }\end{array}$ & $\begin{array}{l}\text { PAN + PRD } \\
119+71+10=200\end{array}$ \\
\hline $\begin{array}{l}\text { Bloqueio de oposição } \\
\text { (para derrubar o veto } \\
\text { presidencial) }\end{array}$ & $\begin{array}{l}\text { De maioria qualificada }=334 \\
\text { votos }\end{array}$ & $\begin{array}{l}\mathrm{PAN}+\mathrm{PRD}+\mathrm{PT} \\
119+71+10=200\end{array}$ \\
\hline
\end{tabular}

Fonte: Tabela elaborada pela autora inspirada no formato apresentado por Bejar (2007: 3) a partir de dados da Secretaria de Gobernación mexicana, constantes do anexo do Sexto Informe de Gobierno 2006

Tabela 3 - Senado - $1^{\circ}$ Triênio do Governo Zedillo (1994-1997)

\begin{tabular}{|c|c|c|}
\hline Senado & Tipo de coalizão & Partidos \\
\hline \multirow[t]{3}{*}{$\begin{array}{l}\text { Bloqueio com o PRI } \\
\text { (em apoio ao governo) }\end{array}$} & Unanimidade $=128$ votos & $\begin{array}{l}\text { PRI+PAN+PRD } \\
95+25+8=128\end{array}$ \\
\hline & $\begin{array}{l}\text { De maioria qualificada }=85 \\
\text { votos }\end{array}$ & $\begin{array}{l}\text { PRI }-95 \\
\text { PRI+PAN } \\
95+25=120 \\
\text { PRI + PRD } \\
95+8=103\end{array}$ \\
\hline & De maioria absoluta $=65$ votos & $\begin{array}{l}\mathrm{PRI}-95 \\
\mathrm{PRI}+\mathrm{PAN} \\
95+25=120 \\
\mathrm{PRI}+\mathrm{PRD} \\
95+8=103\end{array}$ \\
\hline $\begin{array}{l}\text { Bloqueio da oposição } \\
\text { (contra o governo) }\end{array}$ & De maioria absoluta $=65$ votos & $\begin{array}{l}\mathrm{PAN}+\mathrm{PRD} \\
25+8=33\end{array}$ \\
\hline $\begin{array}{l}\text { Bloqueio de oposição } \\
\text { (para derrubar o veto } \\
\text { presidencial) }\end{array}$ & $\begin{array}{l}\text { De maioria qualificada }=85 \\
\text { votos }\end{array}$ & $\begin{array}{l}\mathrm{PAN}+\mathrm{PRD} \\
25+8=33\end{array}$ \\
\hline
\end{tabular}

Fonte: Tabela elaborada pela autora inspirada no formato apresentado por Bejar (2007: 3) a partir de dados da Secretaria de Gobernación mexicana, constantes do anexo do Sexto Informe de Gobierno 2006 
$\underline{\text { Tabela } 4 \text { - Câmara dos Deputados - } 2^{\circ} \text { Triênio do Governo Zedillo (1997-2000) }}$

\begin{tabular}{|c|c|c|}
\hline Câmara dos Deputados & Tipo de coalizão & Partidos \\
\hline \multirow[t]{3}{*}{$\begin{array}{l}\text { Bloqueio com o PRI } \\
\text { (em apoio ao governo) }\end{array}$} & Unanimidade $=500$ votos & $\begin{array}{l}\mathrm{PRI}+\mathrm{PAN}+\mathrm{PRD}+\mathrm{PVE} \\
\mathrm{M}+\mathrm{PT} \\
239+122+125+8+6=5 \\
00\end{array}$ \\
\hline & $\begin{array}{l}\text { De maioria qualificada }=334 \\
\text { votos }\end{array}$ & $\begin{array}{l}\text { PRI +PAN } \\
239+122=361 \\
\text { PRI } \\
+ \text { +PAN+PVEM+PT } \\
239+122+8+6=375 \\
\text { PRI +PAN+PVEM } \\
239+122+8=369 \\
\text { PRI +PAN+PT } \\
\text { 239+122+6=367 } \\
\text { PRI+PRD } \\
\text { 239+125=364 } \\
\text { PRI+PRD+PVEM+P } \\
\text { T } \\
\text { 239+125+8+6=378 } \\
\text { PRI+PRD+PVEM } \\
239+125+8=372 \\
\text { PRI+PRD+PT } \\
\text { 239+125+6=370 }\end{array}$ \\
\hline & $\begin{array}{l}\text { De maioria absoluta }=251 \\
\text { votos }\end{array}$ & $\begin{array}{l}\text { PRI +PAN } \\
239+122=361 \\
\text { PRI } \\
+ \text { +PAN+PVEM+PT } \\
239+122+8+6=375 \\
\text { PRI +PAN+PVEM } \\
239+122+8=369 \\
\text { PRI +PAN+PT } \\
239+122+6=367 \\
\text { PRI+PRD } \\
\text { 239+125=364 } \\
\text { PRI+PRD+PVEM+P } \\
\text { T } \\
239+125+8+6=378 \\
\text { PRI+PRD+PVEM } \\
239+125+8=372 \\
\text { PRI+PRD+PT } \\
239+125+6=370 \\
\text { PRI+PT+PVEM }\end{array}$ \\
\hline
\end{tabular}




\begin{tabular}{|c|c|c|}
\hline & & $239+8+6=253$ \\
\hline $\begin{array}{l}\text { Bloqueio da oposição } \\
\text { (contra o governo) }\end{array}$ & $\begin{array}{l}\text { De maioria absoluta }=251 \\
\text { votos }\end{array}$ & $\begin{array}{l}\mathrm{PAN}+\quad+\quad \mathrm{PRD} \\
+\mathrm{PVEM}+\mathrm{PT} \\
122+125+8+6=261 \\
\mathrm{PAN+PRD+PVEM} \\
122+125+8=255 \\
\mathrm{PAN+PRD+PT} \\
122+125+6=253\end{array}$ \\
\hline $\begin{array}{l}\text { Bloqueio de oposição } \\
\text { (para derrubar o veto } \\
\text { presidencial) }\end{array}$ & $\begin{array}{l}\text { De maioria qualificada }=334 \\
\text { votos }\end{array}$ & $\begin{array}{l}\mathrm{PAN}+\quad+\quad \mathrm{PRD} \\
+\mathrm{PVEM}+\mathrm{PT} \\
122+125+8+6=261\end{array}$ \\
\hline
\end{tabular}

Tabela 5 - Senado - 20 Triênio do Governo Zedillo (1997-2000)

\begin{tabular}{|l|l|l|}
\hline \multicolumn{1}{|c|}{ Senado $^{\mathbf{2 4}}$} & \multicolumn{1}{|c|}{ Tipo de coalizão } & \multicolumn{1}{c|}{ Partidos } \\
\hline $\begin{array}{l}\text { Bloqueio com o PRI } \\
\text { (em apoio ao governo) }\end{array}$ & Unanimidade = 128 votos & $\begin{array}{l}\text { PRI+PAN+PRD+PVE } \\
\text { M+PT } \\
77+33+15+2+1=128\end{array}$ \\
\hline & $\begin{array}{l}\text { De maioria qualificada }=85 \\
\text { votos }\end{array}$ & $\begin{array}{l}\text { PRI+PAN } \\
77+33=110 \\
\text { PRI + PRD } \\
77+15=92\end{array}$ \\
\hline $\begin{array}{l}\text { Bloqueio da oposição } \\
\text { (contra o governo) }\end{array}$ & De maioria absoluta =65 votos & $\begin{array}{l}\text { PRI+PAN } \\
77+33=110 \\
\text { PRI + PRD } \\
77+15=92 \\
\text { Bloqueio de oposição } \\
\text { (para derrubar } \\
\text { presidencial) }\end{array}$ \\
\hline
\end{tabular}

Fonte: Tabela elaborada pela autora inspirada no formato apresentado por Bejar (2007: 3) a partir de dados da Secretaria de Gobernación mexicana, constantes do anexo do Sexto Informe de Gobierno 2006

\footnotetext{
${ }^{24}$ Nas eleições realizadas em 6 de julho de 1997, foram eleitos 32 senadores, a partir de uma lista nacional votada nas cinco circunscrições em que se divide o país, por um período extraordinário de 3 anos, visando adequar o Senado às reformas eleitorais aprovadas em 1996.
} 
Tabela 6 - Câmara dos Deputados - $1^{\circ}$ Triênio do Governo Fox (2000-2003)

\begin{tabular}{|l|l|l|}
\hline \multicolumn{1}{|c|}{ Câmara dos Deputados } & \multicolumn{1}{|c|}{ Tipo de coalizão } & \multicolumn{1}{|c|}{ Partidos } \\
\hline $\begin{array}{l}\text { Bloqueio com o PAN } \\
\text { (em apoio ao governo) }\end{array}$ & Unanimidade =500 votos & $\begin{array}{l}\text { PAN+PRI+PRD+PT+PV } \\
\text { EM+IND } \\
207+206+53+8+16+10= \\
500\end{array}$ \\
\hline & $\begin{array}{l}\text { De maioria qualificada }= \\
334 \text { votos }\end{array}$ & $\begin{array}{l}\text { PAN +PRI } \\
206+207=413\end{array}$ \\
\hline & $\begin{array}{l}\text { De maioria absoluta }=251 \\
\text { votos }\end{array}$ & $\begin{array}{l}\text { PAN +PRI } \\
206+207=413 \\
\text { PAN+PRD } \\
207+53=260\end{array}$ \\
\hline $\begin{array}{l}\text { Bloqueio da oposição } \\
\text { (contra o governo) }\end{array}$ & $\begin{array}{l}\text { De maioria absoluta }=251 \\
\text { votos }\end{array}$ & $\begin{array}{l}\text { PRI+PRD+PT+PVEM+I } \\
\text { ND } \\
206+53+8+16+10=293 \\
\text { PRI+PRD } \\
206+53=259\end{array}$ \\
\hline $\begin{array}{l}\text { Bloqueio de oposição } \\
\text { (para derrubar } \\
\text { presidencial) }\end{array}$ & veto & 334 votos \\
\hline
\end{tabular}

Tabela 7 - Câmara dos Deputados - $2^{\circ}$ Triênio do Governo Fox (2000-2003)

\begin{tabular}{|l|l|l|}
\hline \multicolumn{1}{|c|}{ Câmara dos Deputados } & \multicolumn{1}{|c|}{ Tipo de coalizão } & \multicolumn{1}{c|}{ Partidos } \\
\hline $\begin{array}{l}\text { Bloqueio com o PAN } \\
\text { (em apoio ao governo) }\end{array}$ & Unanimidade $=500$ votos & $\begin{array}{l}\text { PAN+PRI+PRD+PT+PV } \\
\text { EM+CD-PSN+IND } \\
149+224+97+6+17+5+2 \\
=500\end{array}$ \\
\hline & $\begin{array}{l}\text { De maioria qualificada } \\
334 \text { votos }\end{array}$ & $\begin{array}{l}\text { PAN +PRI } \\
149+224=373\end{array}$ \\
\hline & $\begin{array}{l}\text { De maioria absoluta }=251 \\
\text { votos }\end{array}$ & $\begin{array}{l}\text { PAN +PRI } \\
149+224=373 \\
\text { PAN+PRD+PT+PVEM+ } \\
\text { CD-PSN+IND } \\
149+97+6+17+5+2=276\end{array}$ \\
\hline
\end{tabular}




\begin{tabular}{|l|l|l|}
\hline $\begin{array}{l}\text { Bloqueio da oposição } \\
\text { (contra o governo) }\end{array}$ & $\begin{array}{l}\text { De maioria absoluta = 251 } \\
\text { votos }\end{array}$ & $\begin{array}{l}\text { PRI+PRD+PT+PVEM+ } \\
\text { CD-PSN+IND } \\
224+97+6+17+5+2=351 \\
\text { PRI+PRD } \\
206+53=259\end{array}$ \\
\hline $\begin{array}{l}\text { Bloqueio de oposição } \\
\text { (para derrubar o veto } \\
\text { presidencial) }\end{array}$ & $\begin{array}{l}\text { De maioria qualificada } \\
334 \text { votos }\end{array}$ & $\begin{array}{l}\text { PRI+PRD+PT+PVEM+ } \\
\text { CD-PSN+IND } \\
224+97+6+17+5+2=351 \\
\text { PRI+PRD+PT } \\
224+97+17=338\end{array}$ \\
\hline
\end{tabular}

Fonte: Tabela adaptada de Bejar (2007: 3) a partir de dados da Secretaria de Gobernación mexicana, constantes do anexo do Sexto Informe de Gobierno 2006

Tabela 8 - Senado - Sexênio do Governo Fox $(2000-2006)^{25}$

\begin{tabular}{|l|l|l|}
\hline \multicolumn{1}{|c|}{ Senado } & \multicolumn{1}{|c|}{ Tipo de coalizão } & \multicolumn{1}{c|}{ Partidos } \\
\hline $\begin{array}{l}\text { Bloqueio com o PAN } \\
\text { (em apoio ao governo) }\end{array}$ & Unanimidade =128 votos & $\begin{array}{l}\text { PAN+PRI+PRD+PV } \\
\text { EM+IND } \\
47+58+17+5+1=128\end{array}$ \\
\hline & $\begin{array}{l}\text { De maioria qualificada }=85 \\
\text { votos }\end{array}$ & $\begin{array}{l}\text { PAN+PRI } \\
47+58=105\end{array}$ \\
\hline $\begin{array}{l}\text { De maioria absoluta }=65 \text { votos } \\
\text { Bloqueio da oposição } \\
\text { (contra o governo) }\end{array}$ & $\begin{array}{l}\text { PAN+PRI } \\
47+58=105 \\
\text { PAN+PRD+PVEM } \\
47+17+5=69\end{array}$ \\
$\begin{array}{l}\text { Bloqueio de oposição } \\
\text { (para derrubar } \\
\text { presidencial) }\end{array}$ & veto maioria absoluta $=65$ votos & $\begin{array}{l}\text { PRI+PRD } \\
58+17=75 \\
\text { PRI+PVEM+ IND } \\
58+5+1=64\end{array}$ \\
\hline
\end{tabular}

Fonte: Tabela adaptada de Bejar (2007: 3) a partir de dados da Secretaria de Gobernación mexicana, constantes do anexo do Sexto Informe de Gobierno 2006

\footnotetext{
${ }^{25}$ Com o fim das regras eleitorais de transição, não houve eleição intermediária para o Senado em 2003. Os senadores foram eleitos nas eleições de 2000 para um mandato de 6 anos, isto é, até 2006, abrangendo todo o governo Fox.
} 
A tabela 8 , referente à composição do Senado mexicano durante o Governo Fox, demonstra a importância adquirida pelo PRI na construção de coalizões vitoriosas no interior da Câmara Alta. Ao conseguir 58 das 128 cadeiras em disputa, o PRI, embora tenha perdido o controle sobre o Executivo, passou a ser a peça chave para o bloqueio de oposição.

Tendo em vista que as atribuições em matéria de relações exteriores se concentram majoritariamente no Senado, o êxito em fazer frente ao Executivo nesta seara dependeria de uma articulação dos partidos de oposição em torno do Partido Revolucionário Institucional.

\section{LEGISLAÇÃ̃O SUBSTANTIVA}

O êxito do Congresso na aprovação de leis substantivas em matéria de política exterior foi baixo. No período de $1^{\text {o }}$ de setembro de 1997 a 31 de agosto de 2000, foram apresentadas 21 iniciativas tendo por objeto temas de relações exteriores, das quais 2 foram aprovadas, 1 rejeitada e as 18 restantes continuam pendentes em suas comissões de origem $^{26}$.

Os principais temas abordados nas iniciativas são: a) modificações na Lei de Serviço Exterior mexicana; b) fortalecimento das ações de integração com os povos da América Latina; c) reformas na lei de investimentos estrangeiros, para admitir a participação de capital privado estrangeiro na indústria petroquímica; d) criação de uma lei de zonas de livre comércio; e) regulação dos tratados internacionais.

As iniciativas aprovadas se referem à permissão de importação para a internação definitiva de veículos estrangeiros que estavam temporariamente no país e ao aumento na quota de recursos aportados pelo México junto ao Fundo Monetário Internacional.

\footnotetext{
${ }^{26}$ O levantamento de dados sobre legislação substantiva referentes à LVI Legislatura ficou prejudicado, uma vez que não existem registros sobre este período no Sistema de Informação Legislativa da Secretaria de Governo do México. Os diários de debates do Senado e da Câmara dos Deputados apresentam apenas as iniciativas que foram à votação, não existindo informações a respeito dos projetos que ficaram pendentes em comissões de origem. No período em questão, foi aprovada a Lei de Proteção ao Comércio e Investimentos Estrangeiros.
} 
No período de $1^{\circ}$ de setembro de 2000 a 31 de agosto de 2006, foram apresentadas 93 iniciativas com temática internacional, das quais 28 foram aprovadas, 39 foram rejeitadas e 26 permaneceram pendentes nas comissões de origem.

Os principais temas abordados nas iniciativas são: a) restrições à importação de carnes e leites; b) alterações na Lei de Comércio Exterior; c) ab-rogação da lei para conservar a neutralidade do país; d) modificações na Lei de Serviço Exterior, para que a nomeação de embaixadores e cônsules recaia exclusivamente em funcionários de carreira; e) regulamentação do setor petrolífero; f) alterações na Lei Aduaneira; g) criação de um Conselho Nacional de Política Exterior; h) incorporação da defesa e promoção dos direitos humanos como princípio de condução da política externa; i) estabelecimento da exclusividade dos mexicanos na exploração de recursos pesqueiros; j) o reconhecimento da capacidade jurídica das entidades federativas para celebrar acordos internacionais; 1) renegociação do capítulo agropecuário do NAFTA.

Entre as propostas aprovadas destacam-se as reformas na Lei do Serviço Exterior Mexicano; a reforma do artigo 21 da Constituição, para facilitar o ingresso do México no Estatuto de Roma; a alteração de artigos do Código Penal Federal sobre terrorismo; a Lei para simplificação dos procedimentos de comércio exterior; a Lei para autorização de negociações comerciais com o exterior e medidas de proteção ao mercado interno pecuário.

Um dos projetos pendentes se referia à reforma no setor energético, para que este pudesse receber investimentos estrangeiros. A iniciativa encontrou especial resistência por parte de senadores do PRI e do PRD.

Em maio de 2006, o Presidente Fox vetou um projeto de lei aprovado pelo Congresso, que autorizava o porte de certa quantidade de droga. A postura de Fox foi complacente com os interesses norte-americanos, os quais acreditavam que a medida, na prática, implicaria na descriminalização do consumo de drogas. 
Tabela 9 - Iniciativas substantivas em matéria de relacões exteriores

\begin{tabular}{|c|c|c|c|c|c|}
\hline Legislatura & Apresentadas & Aprovadas & Pendentes & Rejeitadas & $\begin{array}{c}\text { Porcentagem de } \\
\text { aprovação }\end{array}$ \\
\hline LVI $^{27}$ & 7 & 3 & 2 & 1 & $42,85 \%$ \\
\hline LVII & 21 & 2 & 18 & 1 & $9,52 \%$ \\
\hline LVIII & 37 & 19 & 0 & 18 & $51,35 \%$ \\
\hline LXIX & 56 & 9 & 26 & 21 & $16,07 \%$ \\
\hline
\end{tabular}

Fonte: Tabela elaborada pela autora a partir de dados extraídos do Sistema de Informação Legislativa do Governo Mexicano e do site da Câmara dos Deputados mexicana

\section{LEGISLAÇÃO PROCEDIMENTAL}

O principal ponto de atrito entre o Congresso e o Executivo, em especial durante o governo Fox, refere-se à apresentação de propostas de alteração das prerrogativas constitucionais em matéria de relações exteriores. Ambos os poderes tinham interesse direto em ampliar suas atribuições na condução da política externa do país.

O número de propostas desse tipo cresceu desde o fim do regime autoritário, o que demonstra um maior interesse do Congresso em ampliar seus poderes nesta seara, embora não haja consenso sobre a maneira pela qual deve ser realizada essa ampliação.

Os congressistas, visando ampliar o controle sobre ações do Executivo em matéria de política externa, propuseram diversas reformas aos artigos 76 e 89 da Constituição mexicana, tendo por objeto a criação de mecanismos que façam da área internacional uma temática de responsabilidade conjunta entre o Executivo e o Legislativo.

Destacam-se, no entanto, a aprovação de dois projetos, com impacto significativo sobre as atribuições do Congresso, em especial do Senado, em política externa. O primeiro deles se refere à reforma na fração I do artigo 76, para incluir a faculdade do Senado de aprovar, não só o ato de adesão ao tratado, mas também qualquer outro ato dele decorrente, como o término, a denúncia, a suspensão, a modificação, a emenda, a retirada de reservas e a formulação de declarações interpretativas sobre o instrumento internacional.

\footnotetext{
${ }^{27}$ Os dados abrangem apenas as iniciativas apresentadas na Câmara dos Deputados durante o período e as iniciativas submetidas à votação no Senado. As votações porventura apresentadas pelo Senado e pendentes não puderam ser computadas pela falta de dados no site do Senado mexicano.
} 
O segundo instrumento, aprovado em 2004, foi a Lei sobre Aprovação de Tratados Internacionais em Matéria Econômica. Com conteúdo híbrido, a nova lei fixa objetivos a serem observados na assinatura de tratados internacionais, além de impor ao Executivo o dever de informar periodicamente o Congresso a respeito das etapas das negociações de um tratado.

Durante a LVII Legislatura, foram apresentadas 9 iniciativas visando alterar o sistema constitucional de competências em matéria de política externa e todas se encontram pendentes em suas comissões de origem.

O conteúdo das reformas abrangia: a) o fim da necessidade de autorização do Senado para a saída de tropas do território nacional em casos de ajuda humanitária que não excedessem 1 ano; b) extensão à Câmara dos Deputados da faculdade de aprovar tratados internacionais; c) o fim da necessidade de aprovação pelo Legislativo de autorizações para o desempenho de serviço em consulados e embaixadas; d) aprovação pelo Senado da política de investimentos estrangeiros e da autorização para investimentos em setores de regulação específica; e) aprovação pelo Senado dos instrumentos internacionais relacionados à segurança pública e nacional.

Nas LVIII e LIX Legislaturas, foram apresentadas 30 iniciativas, das quais 4 foram aprovadas, 8 foram rejeitadas e 18 ainda estão pendentes nas comissões de origem.

As reformas propostas neste período tinham por objeto: a) aumento da participação do Senado na condução da política externa através da criação dos instrumentos de mandamento e exortação; b) incorporação de representações do Congresso nas negociações internacionais; c) ratificação pelo Senado do Ministro das Relações Exteriores; d) ratificação pelo Senado dos acordos executivos, interinstitucionais, pactos, memorandos e protocolos; e) aprovação pelo Senado do voto proferido pelas delegações mexicanas em organismos internacionais; f) extensão à Câmara dos Deputados da faculdade para ratificação de tratados internacionais; g) participação do Senado em processos de negociação internacional; h) ratificação pelo Senado da remoção de embaixadores e cônsules gerais.

Os quatro projetos aprovados são a Lei sobre Aprovação de Tratados Internacionais em matéria econômica, a criação de mecanismos para negociações internacionais com o exterior e duas reformas constitucionais para ampliar a competência 
do Senado para aprovar todos os atos relacionados a instrumentos internacionais, entre os quais foram incluídos os acordos executivos, interinstitucionais, pactos e memorandos.

Tabela 10 - Iniciativas procedimentais em matéria de relacões exteriores

\begin{tabular}{|c|c|c|c|c|c|}
\hline Legislatura & Apresentadas & Aprovadas & Pendentes & Rejeitadas & $\begin{array}{c}\text { Porcentagem de } \\
\text { aprovação }\end{array}$ \\
\hline LVI $^{28}$ & 2 & 0 & 2 & 0 & $0 \%$ \\
\hline LVII & 9 & 0 & 9 & 0 & $0 \%$ \\
\hline LVIII & 15 & 2 & 12 & 1 & $13,33 \%$ \\
\hline LXIX & 15 & 2 & 6 & 7 & $13,33 \%$ \\
\hline
\end{tabular}

Fonte: Tabela elaborada pela autora a partir de dados do Sistema de Informação Legislativa do Governo Mexicano e do site da Câmara dos Deputados mexicana

Conforme se pode notar, a maior parte das propostas teve por objeto a alteração de dispositivos relacionados à aprovação dos tratados internacionais. Neste aspecto, foi destacado o papel da Câmara dos Deputados na apresentação de projetos que visavam estender a faculdade de ratificação também à Câmara Baixa. A tabela abaixo ilustra as iniciativas apresentadas pelos deputados nas LVIII e LIX Legislaturas, período de maior atividade legislativa:

Tabela 11 - Iniciativas da Câmara dos Deputados em matéria de aprovacão de tratados internacionais nas LVIII e LIX Legislaturas

\begin{tabular}{|c|c|}
\hline \multicolumn{1}{|c|}{$\begin{array}{c}\text { Data de } \\
\text { apresentação }\end{array}$} & \multicolumn{1}{c|}{ Conteúdo da iniciativa } \\
\hline 22 de março de 2001 & $\begin{array}{l}\text { Iniciativa de reforma a diversas disposições da Constituição com relação ao Poder } \\
\text { Executivo apresentada pelo Deputado Amador Rodriguez Lozano, do PRI (artigo 76). }\end{array}$ \\
\hline 9 de outubro de 2001 & $\begin{array}{l}\text { Iniciativa de reforma a diversos artigos da Constituição sobre política exterior } \\
\text { apresentada pelo deputado Marti Batres Guadarrama, do PRD (artigos 73, 76, 89 e 33). }\end{array}$ \\
\hline 4 de dezembro de 2001 & $\begin{array}{l}\text { Iniciativa de reforma a diversos artigos da Constituição, como fim de obter uma nova } \\
\text { distribuição entre os Poderes Executivo e Legislativo, apresentada pelo deputado Eric }\end{array}$ \\
\hline
\end{tabular}

\footnotetext{
${ }^{28}$ Pelos mesmos motivos expostos na nota anterior, foram consideradas apenas as iniciativas apresentadas na Câmara dos Deputados e as iniciativas submetidas à aprovação no Senado.
} 


\begin{tabular}{|c|c|}
\hline & Eber Villanueva Mukul, do PRD (artigos 76 e 89) \\
\hline 6 de fevereiro de 2001 & $\begin{array}{l}\text { Iniciativa com projeto de decreto que reforma os artigos } 73 \text { e } 76 \text { da Constituição, } \\
\text { apresentada pela deputada Miroslava Garcia Suarez, do PRD }\end{array}$ \\
\hline 4 de abril de 2002 & $\begin{array}{l}\text { Iniciativa que adiciona o inciso VI ao artigo } 73 \text { e reforma os artigos } 76,89 \text { e } 133 \text { da } \\
\text { Constituição, apresentada pelo deputado Miguel Barbosa Huerta, do PRD }\end{array}$ \\
\hline Data não disponível & $\begin{array}{l}\text { Iniciativa de reforma aos artigos 73; 76, inciso I; 89, inciso X e } 133 \text { da Constituição, a } \\
\text { cargo da Deputada Norma Patricia Riojas Santana, do Partido da Sociedade } \\
\text { Nacionalista. }\end{array}$ \\
\hline 14 de abril de 2002 & $\begin{array}{l}\text { Iniciativa que reforma os artigos } 74 \text { e } 89 \text { da Constituição; o artigo } 28 \text { da Lei Orgânica } \\
\text { da Administração Pública Federal e os artigos } 1^{\circ}, 58 \text { e } 59 \text { da Lei do Serviço Exterior } \\
\text { Mexicano, apresentada pelo deputado José Soto Martinez, do PRI. }\end{array}$ \\
\hline $1^{\circ}$ de abril de 2003 & $\begin{array}{l}\text { Iniciativa que reforma os artigos } 76,89 \text { e } 133 \text { da Constituição em matéria de tratados } \\
\text { internacionais, apresentada pelo Deputado José Elias Romero Apis, do PRI }\end{array}$ \\
\hline 28 de abril de 2003 . & $\begin{array}{l}\text { Iniciativa de reforma aos artigos 73, 76, } 89 \text { e } 133 \text { da Constituição e artigos 2, } 4 \text { e } 5 \text { da } \\
\text { Lei sobre Celebração de Tratados, apresentada pelo Deputado Enrique Martinez Orta } \\
\text { Flores, do PRI }\end{array}$ \\
\hline 29 de abril de 2003. & $\begin{array}{l}\text { Iniciativa com projeto de decreto, por meio do qual se adiciona o inciso XXXI ao } \\
\text { artigo } 73 \text {; alteram-se o inciso I do artigo } 76 \text {, o inciso X do artigo } 89 \text {, o artigo 133; } \\
\text { derrogam-se o inciso XII do artigo } 73 \text { e o inciso VIII do artigo } 89 \text { da Constituição, } \\
\text { apresentada pelo deputado Jaime Cervantes Rivera, do PT }\end{array}$ \\
\hline 18 de março de 2004 & $\begin{array}{l}\text { Iniciativa que reforma a denominação do capítulo I do título primeiro, adiciona o } \\
\text { parágrafo } 4^{\circ} \text { ao artigo } 1^{\circ} \text { e os parágrafos } 4^{\circ} \text { e } 5^{\circ} \text { ao artigo } 17 \text {; reformam-se os artigos } \\
19,89 \text {, inciso X e } 103 \text {, inciso I; adiciona o parágrafo terceiro ao artigo } 113 \text { e um } \\
\text { parágrafo segundo ao artigo } 133 \text {, todos da Constituição, apresentada pela deputada } \\
\text { Eliana Garcia Laguna, do PRD }\end{array}$ \\
\hline
\end{tabular}

Fontes: Tabela elaborada pela autora a partir de dados dos Diários de Debates da Câmara dos Deputados mexicana

A análise da tabela releva alguns aspectos interessantes a respeito das iniciativas apresentadas pela Câmara dos Deputados. Seis iniciativas propõem que o artigo 73 preveja a competência do Congresso de aprovar os tratados internacionais celebrados pelo Executivo e uma das iniciativas propõe que seja faculdade exclusiva da Câmara dos 
Deputados aprovar anualmente as orientações de política exterior propostas pelo Executivo.

No tocante especificamente aos artigos da Constituição em matéria de condução de política externa, as reformas propostas em relação ao artigo 76 se referem à participação do Senado em negociações dos tratados internacionais; à derrogação do inciso I; à competência exclusiva do Senado de aprovar previamente os tratados celebrados pelo Executivo; à supressão da faculdade exclusiva do Senado de aprovar os tratados e à competência exclusiva do Senado para analisar em primeira instância os tratados internacionais para posteriormente enviá-los ao Congresso da União para aprovação.

As reformas referentes ao artigo 89 propõem que o Executivo deve pedir a aprovação do Congresso para celebrar tratados; os tratados devem ser aprovados pelo Congresso da União; o Executivo deve solicitar autorização prévia do Senado para celebrar tratados; o Presidente deve conduzir a política externa de acordo com as orientações aprovadas pela Câmara dos Deputados; deve ser estabelecido o princípio normativo de respeito, promoção e defesa dos direitos humanos, bem como que os tratados sobre direitos humanos não podem ser denunciados.

Por fim, as reformas em relação ao artigo 133 dispõem que os tratados celebrados pelo Executivo devem ser aprovados pelo Congresso; os tratados celebrados pelo Executivo devem ser aprovados pelo Congresso por 1/3 dos integrantes de cada uma das Câmaras e que os preceitos contidos em tratados sobre Direitos Humanos terão hierarquia constitucional.

Os debates travados nas duas Casas do Congresso em relação a tais reformas relevam, de um lado, a intenção de ampliar os poderes do Legislativo na condução da política externa para fazer frente ao Executivo, e de outro, ressalvas quanto à maneira pela qual deve se dar esta ampliação. A Câmara dos Deputados se mostra especialmente reticente quanto à concentração excessiva das faculdades no Senado. 


\section{MEIOS INDIRETOS}

Outro importante instrumento de que dispõe o Congresso mexicano para influenciar a política externa são os pontos de acordo ("puntos de acuerdo"), os quais, embora não apresentem força normativa ou poder vinculante, demonstram a concordância dos legisladores em relação a um determinado tema ou postura a ser adotada. Existem diversos tipos de pontos de acordo: as simples exortações; as requisições de informação; solicitações de comparecimento, por meio das quais membros do governo são requisitados para prestar esclarecimentos sobre a política da administração; censuras ("extrañamientos") e reclamações.

Para Velázquez (2007: 24-25), diversos fatores determinam o acatamento pelo Executivo de um ponto de acordo, entre os quais se destacam: a) se o assunto coincide com sua posição e não afeta um interesse maior; b) se o ponto de acordo surgiu do interior do Executivo e foi capitaneado por membros do partido no Congresso; c) se o objetivo é evitar uma confrontação com o Congresso que tenha um custo político muito alto; d) se a pressão dos legisladores é muito grande.

Os principais temas abordados nos pontos de acordo foram a imigração Estados Unidos/México, tráfico de drogas, segurança, comércio, direitos humanos, Cuba e meioambiente. De um modo geral, as temáticas da imigração e direitos humanos foram capazes de gerar maior consenso no interior do Congresso.

No período de $1^{\circ}$ de setembro de 1994 a 31 de agosto de 2000, foram apresentados ao Congresso 105 pontos de acordo sobre temas de política externa, dos quais 50 foram aprovados, 54 ficaram pendentes nas comissões de origem e 1 foi rejeitado.

O único ponto de acordo rejeitado refere-se a um pedido de intervenção da Cruz Vermelha, para que auxilie grupos na Província de Chiapas. Os pontos de acordo aprovados versavam sobre: a) expedição de resolução pela SECOFI, determinando a aplicação de tarifas à importação de carne dos Estados Unidos; b) narcotráfico; c) construção de depósitos radioativos no Texas; d) revisão do capítulo agropecuário do NAFTA; e) violação aos direitos humanos dos imigrantes mexicanos; f) condenação dos 
ataques aéreos da Organização do Tratado do Atlântico Norte (OTAN); g) defesa da soberania nacional; h) postura dos Estados Unidos em relação a Cuba; i) imigração.

No período de $1^{\circ}$ de setembro de 2000 a 31 de agosto de 2006, foram apresentados ao Congresso 887 pontos de acordo sobre temática internacional, dos quais 472 foram aprovados, 323 ficaram pendentes nas comissões de origem e 92 foram rejeitados. Entre os pontos de acordo aprovados, destacam-se as seguintes temáticas: a) voto do México sobre Cuba na Comissão de Direitos Humanos da ONU; b) abusos sofridos por mexicanos residentes nos Estados Unidos; c) conflito Israel-Palestina; d) impacto do NAFTA sobre o setor agropecuário; e) direitos humanos dos trabalhadores mexicanos imigrantes; f) repúdio ao uso de força no Iraque; g) fim do bloqueio econômico a Cuba; h) relações diplomáticas com Cuba.

Neste período, foram aprovadas três moções de censura ao Secretário de Relações Exteriores Luis Ernesto Derbez, em razão de seu voto na Comissão de Direitos Humanos na ONU contra Cuba, por descuidar das atribuições de seu cargo quando foi candidato a Secretário Geral da OEA e por não dar a devida atenção aos assuntos relacionados à imigração.

Tabela 12 - Pontos de Acordo em matéria de relacões exteriores apresentados $\underline{\text { na LVI Legislatura }}{ }^{29}$

\begin{tabular}{|l|l|l|l|l|l|}
\hline & Apresentados & Aprovados & Pendentes & Rejeitados & $\begin{array}{l}\text { Porcentagem de } \\
\text { aprovação }\end{array}$ \\
\hline $\begin{array}{l}\text { Proposição } \\
\text { com ponto de } \\
\text { acordo em } \\
\text { matéria de } \\
\text { relações } \\
\text { exteriores }\end{array}$ & 13 & 13 & 0 & 0 & $100 \%$ \\
\hline
\end{tabular}

Fonte: Tabela elaborada pela autora a parir de dados dos Diários de Debates da Câmara dos Deputados e Senado mexicanos

\footnotetext{
${ }^{29}$ Mais uma vez, a ausência de dados sobre esta legislatura no Sistema de Informação Legislativa da Secretaria de Governo do México prejudicou a contagem exata do número de pontos de acordo apresentados no período. O número constante na tabela se refere aos pontos de acordo que foram submetidos à votação no Senado mexicano. Os pontos de acordo pendentes nas comissões não puderam ser contabilizados.
} 
Tabela 13 - Pontos de Acordo em matéria de relacões exteriores apresentados na LVII Legislatura

\begin{tabular}{|c|c|c|c|c|c|}
\hline & Apresentados & Aprovados & Pendentes & Rejeitados & $\begin{array}{c}\text { Porcentagem de } \\
\text { aprovação }\end{array}$ \\
\hline $\begin{array}{c}\text { Censuras/ } \\
\text { exortações ao } \\
\text { Executivo }\end{array}$ & 24 & 7 & 17 & 0 & $29,16 \%$ \\
\hline $\begin{array}{c}\text { Pedidos de } \\
\text { comparecimento }\end{array}$ & 10 & 3 & 7 & 0 & $30 \%$ \\
\hline $\begin{array}{c}\text { Pedidos de } \\
\text { informação ao } \\
\text { Executivo }\end{array}$ & 0 & 0 & 0 & 0 & - \\
\hline $\begin{array}{c}\text { Criação de } \\
\text { comissões ou } \\
\text { grupos de } \\
\text { trabalho }\end{array}$ & 2 & 1 & 1 & 0 & $50 \%$ \\
\hline $\begin{array}{c}\text { Exorto/solicitação } \\
\text { ao Legislativo }\end{array}$ & 44 & 20 & 24 & 0 & $45,45 \%$ \\
\hline Outros & 12 & 6 & 5 & 1 & $50 \%$ \\
\hline Total & 92 & 37 & 54 & 1 & $68,5 \%$ \\
\hline
\end{tabular}

Fonte: Sistema de Informação Legislativa do Governo Mexicano

Tabela 14 - Pontos de Acordo em matéria de relacões exteriores apresentados na LVIII Legislatura

\begin{tabular}{|c|c|c|c|c|c|}
\hline & Apresentados & Aprovados & Pendentes & Rejeitados & $\begin{array}{c}\text { Porcentagem de } \\
\text { Aprovação }\end{array}$ \\
\hline $\begin{array}{c}\text { Censuras/exortações ao } \\
\text { Executivo }\end{array}$ & 185 & 69 & 105 & 11 & $37,29 \%$ \\
\hline $\begin{array}{c}\text { Pedidos de } \\
\text { comparecimento }\end{array}$ & 25 & 11 & 14 & 0 & $44 \%$ \\
\hline $\begin{array}{c}\text { Pedidos de informação ao } \\
\text { Executivo }\end{array}$ & 9 & 3 & 5 & 1 & $33,33 \%$ \\
\hline $\begin{array}{c}\text { Criação de comissões ou } \\
\text { grupos de trabalho }\end{array}$ & 6 & 0 & 6 & 0 & $0 \%$ \\
\hline $\begin{array}{c}\text { Exorto/solicitações ao } \\
\text { Legislativo }\end{array}$ & 54 & 23 & 28 & 3 & $42,59 \%$ \\
\hline Outros & 18 & 7 & 10 & 1 & $38,88 \%$ \\
\hline Total & 297 & 113 & 168 & 16 & $38 \%$ \\
\hline
\end{tabular}

Fonte: Sistema de Informação Legislativa do Governo Mexicano 
Tabela 15 - Pontos de Acordo em matéria de relacões exteriores apresentados na LIX Legislatura

\begin{tabular}{|c|c|c|c|c|c|}
\hline & Apresentados & Aprovados & Pendentes & Rejeitados & $\begin{array}{c}\text { Porcentagem de } \\
\text { aprovação }\end{array}$ \\
\hline $\begin{array}{c}\text { Censuras/exortações } \\
\text { ao Executivo }\end{array}$ & 286 & 166 & 70 & 50 & $58 \%$ \\
\hline $\begin{array}{c}\text { Pedidos de } \\
\text { comparecimento }\end{array}$ & 58 & 37 & 17 & 4 & $63,79 \%$ \\
\hline $\begin{array}{c}\text { Pedidos de } \\
\text { informação ao } \\
\text { Executivo }\end{array}$ & 63 & 42 & 18 & 2 & $66,66 \%$ \\
\hline $\begin{array}{c}\text { Criação de } \\
\text { comissões ou } \\
\text { grupos de trabalho }\end{array}$ & 13 & 7 & 6 & 0 & $53,84 \%$ \\
\hline $\begin{array}{c}\text { Exorto/solicitações } \\
\text { ao Legislativo }\end{array}$ & 74 & 48 & 19 & 7 & $64,86 \%$ \\
\hline Outros & 96 & 59 & 25 & 13 & $61,45 \%$ \\
\hline Total & 590 & 359 & 155 & 76 & $60,84 \%$ \\
\hline
\end{tabular}

Fontes: Sistema de Informação Legislativa do Governo Mexicano

Os acordos parlamentares, a exemplo dos pontos de acordo, são manifestações dos grupos parlamentares que compõem o Congresso sobre temas de política externa sem força vinculante.

Nas LVI e LVII Legislaturas, foram apresentados ao Congresso mexicano 30 acordos parlamentares, todos aprovados. Os acordos tinham por objeto: a) o comparecimento do Secretário de Relações Exteriores, b) os incidentes na fronteira México-Estados Unidos, c) a constituição de grupos parlamentares de amizade, d) visitas de Presidentes, e) comissões do Parlamento Latino Americano. Os dois acordos parlamentares apresentados na LVI Legislatura referiam-se a uma demanda junto ao governo norte-americano sobre os direitos humanos dos imigrantes mexicanos e uma manifestação de repúdio à "Operação Rio Grande", na fronteira com os Estados Unidos.

Nas LVIII e LIX, foram submetidos à apreciação do Congresso e aprovados 45 acordos parlamentares sobre relações exteriores. Os temas abrangidos pelos acordos são os mais variados, entre os quais vale mencionar: a) proposta de diálogo para a superação das diferenças diplomáticas; b) conflito no Oriente Médio; c) fixação de parâmetros para a autorização de viagens internacionais do Presidente; d) criação de grupos de trabalho 
sobre a ALCA; e) voto contra o bloqueio econômico a Cuba; f) convite à relatora das Nações Unidas sobre Direitos Humanos dos Imigrantes para que fizesse uma visita à fronteira.

$\underline{\text { Tabela } 16 \text { - Acordos Parlamentares em matéria de relacões exteriores }}$ apresentados na LVI Legislatura $^{30}$

\begin{tabular}{|c|c|c|c|c|c|}
\hline & Apresentados & Aprovados & Pendentes & Rejeitados & $\begin{array}{c}\text { Porcentagem de } \\
\text { aprovação }\end{array}$ \\
\hline $\begin{array}{c}\text { Acordos } \\
\text { Parlamentares } \\
\text { em matéria de } \\
\text { relações } \\
\text { exteriores }\end{array}$ & 2 & 2 & 0 & 0 & $100 \%$ \\
\hline
\end{tabular}

Fonte: Tabela elaborada pela autora a partir de dados obtidos nos Diários de Debates da Câmara dos Deputados e Senado mexicanos

Tabela 17 - Acordos Parlamentares em matéria de relações exteriores apresentados na LVII Legislatura

\begin{tabular}{|c|c|c|c|c|c|}
\hline & Apresentados & Aprovados & Pendentes & Rejeitados & Taxa de aprovação \\
\hline $\begin{array}{c}\text { Criação de } \\
\text { comissões ou } \\
\text { grupos de } \\
\text { trabalho }\end{array}$ & 7 & 7 & 0 & 0 & $100 \%$ \\
\hline $\begin{array}{c}\text { Censuras/ } \\
\text { exortações ao } \\
\text { Executivo }\end{array}$ & 0 & 0 & 0 & 0 & \\
\hline $\begin{array}{c}\text { Pedidos de } \\
\text { comparecimento }\end{array}$ & 2 & 2 & 0 & 0 & $100 \%$ \\
\hline $\begin{array}{c}\text { Pedidos de } \\
\text { informação ao } \\
\text { Executivo }\end{array}$ & 0 & 0 & 0 & 0 & \\
\hline Outros & 19 & 19 & 0 & 0 & $100 \%$ \\
\hline Total & 28 & 28 & 0 & 0 & $100 \%$ \\
\hline
\end{tabular}

Fonte: Sistema de Informação Legislativa do Governo Mexicano

\footnotetext{
30 A mesma observação constante na nota de $n^{\circ} 29$ se aplica à presente. Os Acordos Parlamentares constantes da tabela são os únicos submetidos à aprovação no Senado mexicano. Eventuais acordos pendentes não constam da contagem.
} 
Tabela 18-Acordos Parlamentares em matéria de relacões exteriores apresentados na LVIII Legislatura

\begin{tabular}{|c|c|c|c|c|c|}
\hline & Apresentados & Aprovados & Pendentes & Rejeitados & $\begin{array}{c}\text { Taxa de } \\
\text { aprovação }\end{array}$ \\
\hline $\begin{array}{c}\text { Criação de comissões } \\
\text { ou grupos de trabalho }\end{array}$ & 1 & 1 & 0 & 0 & $100 \%$ \\
\hline $\begin{array}{c}\text { Censuras/ exortações } \\
\text { ao Executivo }\end{array}$ & 1 & 1 & 0 & 0 & $100 \%$ \\
\hline $\begin{array}{c}\text { Pedidos de } \\
\text { comparecimento }\end{array}$ & 0 & 0 & 0 & 0 & $100 \%$ \\
\hline $\begin{array}{c}\text { Pedidos de } \\
\text { informação ao } \\
\text { Executivo }\end{array}$ & 0 & 0 & 0 & 0 & \\
\hline Outros & 2 & 2 & 0 & 0 & $100 \%$ \\
\hline Total & 4 & 4 & 0 & 0 & $100 \%$ \\
\hline
\end{tabular}

Fonte: Sistema de Informação Legislativa do Governo Mexicano

Tabela 19-Acordos Parlamentares em matéria de relacões exteriores apresentados na LIX Legislatura

\begin{tabular}{|l|l|l|l|l|l|}
\hline & Apresentados & Aprovados & Pendentes & Rejeitados & $\begin{array}{l}\text { Taxa de } \\
\text { aprovação }\end{array}$ \\
\hline $\begin{array}{l}\text { Criação de comissões } \\
\text { ou grupos de trabalho }\end{array}$ & 2 & 2 & 0 & 0 & $100 \%$ \\
\hline $\begin{array}{l}\text { Censuras/ exortações } \\
\text { ao Executivo }\end{array}$ & 16 & 16 & 0 & 0 & $100 \%$ \\
\hline $\begin{array}{l}\text { Pedidos de } \\
\text { comparecimento }\end{array}$ & 2 & 2 & 0 & 0 & $100 \%$ \\
\hline $\begin{array}{l}\text { Pedidos de } \\
\text { informação ao } \\
\text { Executivo }\end{array}$ & 0 & 0 & 0 & 0 & \\
\hline Outros & 21 & 28 & 0 & 0 & $100 \%$ \\
\hline Total & 41 & 41 & 0 & 0 & $100 \%$ \\
\hline
\end{tabular}

Fonte: Sistema de Informação Legislativa do Governo Mexicano

Além dos pontos de acordo e dos acordos parlamentares, outro meio indireto de que dispõe o Congresso mexicano para influenciar a política externa do país se refere à participação em organismos parlamentares internacionais e realização de viagens. Os 
fóruns internacionais servem como instrumento de troca de experiências entre os congressistas, estreitando os vínculos com representantes de outros países.

O levantamento de dados ficou parcialmente prejudicado quanto a este aspecto, uma vez que a impossibilidade de realização de trabalhos de pesquisa in loco tornou o acesso a fontes informativas mais restrito. Os endereços eletrônicos da Câmara dos Deputados e do Senado possuem este tipo de dado apenas em relação às duas últimas Legislaturas (LX e LXI), razão pelo qual nos limitamos a listar os organismos internacionais dos quais participa o Congresso mexicano.

Atualmente, o Congresso mexicano participa das seguintes organizações:

a) União Interparlamentar, constituída em 1889, compartilha os objetivos das Nações Unidas, trabalhando em favor da paz, da cooperação entre os povos e da consolidação das instituições representativas. O organismo é composto por grupos parlamentares de mais de 130 países e tem sede em Genebra. Entre as funções específicas, está a de favorecer os contatos, a coordenação e intercâmbio de experiências entre os parlamentares de todo o mundo; o exame de questões de interesse internacional, pronunciando-se, a fim de alavancar a ação dos parlamentares; contribuir para a defesa e promoção dos direitos humanos; contribuir para a difusão do conhecimento a respeito das instituições representativas.

b) Parlamento Latinoamericano, constituído em 1964, é composto pelos parlamentos nacionais de 22 países $^{31}$. Por meio de treze comissões permanentes e sete especiais, realiza projetos que fomentam a integração latinoamericana nas mais diversas áreas, meio ambiente, questões indígenas, dívida externa.

O Senado mexicano mantém reuniões bilaterais anuais com representantes do Congresso dos Estados Unidos, Guatemala, Belize, Cuba, Chile e Espanha, além de participar de grupos de amizade periódicos com países como Alemanha, Argentina, Austrália, Brasil, Bulgária, China, Dinamarca, entre outros.

As iniciativas interparlamentares do Congresso mexicano se estendem também a atividades com a Ásia e Europa, tais como: as reuniões anuais do Foro Parlamentar Asia-

\footnotetext{
${ }^{31}$ Antilhas Holandesas, Argentina, Aruba, Bolívia, Brasil, Chile, Colômbia, Costa Rica, Cuba, Equador, El Salvador, Guatemala, Honduras, México, Nicarágua, Panamá, Paraguai, Peru, República Dominicana, Suriname, Uruguai e Venezuela.
} 
Pacífico, do qual participam congressistas dos países do Pacífico Asiático, Austrália, Nova Zelândia, México, Estados Unidos, Canadá e Chile; a realização de reuniões de trabalho com o Parlamento Europeu; e reuniões da Comissão Econômica e de Desenvolvimento da Assembléia Parlamentar do Conselho da Europa, do qual fazem parte congressistas de cerca de quarenta países da Europa.

Em que pese a participação do Congresso em diversos canais de interlocução internacional e o esforço de estruturação de órgãos com capacidade de auxílio consultivo em questões de política externa, o nível de preparo e expertise dos congressistas para enfrentar temas de âmbito internacional é bastante limitado, o que dificulta uma atuação mais consistente por parte do Legislativo. Segundo González (2007), um dos fatores que limitam a capacidade do Congresso de formar corpos consultivos mais qualificados é a proibição da reeleição, a qual limita o horizonte temporal de preocupação dos congressistas.

\section{SEÇÃO II - A VARIÁ VEL NÍVEL DE DIVERGÊNCIA - DIAGNÓSTICO DA ASSERTIVIDADE}

A variável nível de divergência em política externa será medida a partir de dois indicadores: a) nível de divergência entre os partidos políticos mexicanos, aferido por meio das plataformas eleitorais apresentadas nas eleições de 2006; b) nível de divergência entre o Congresso e o Executivo, medido a partir do exercício do poder de veto pelos congressistas na ratificação de tratados internacionais, pedidos de autorização de viagem do Presidente da República, nomeações diplomáticas e autorizações para o uso de condecorações, bem como das reações do Legislativo Nacional frente a temas internacionais que geraram atritos entre os poderes.

O levantamento de dados sobre os instrumentos internacionais, pedidos de autorização de viagem, nomeações diplomáticas e permissão para uso de condecorações submetidos à votação seguiu a mesma sistemática apresentada na seção anterior.

As tabelas de dados, elaboradas por legislatura, apresentam o número total de instrumentos internacionais/pedidos de viagem/nomeações/autorizações submetidos à votação, o número de aprovados, o número de pendentes e o número de rejeitados. A 
porcentagem de aprovação, calculada ao final, expressa a taxa de êxito do Executivo, que detém o poder de iniciativa sobre essas temáticas, em impor suas preferências.

Para o cálculo da taxa de aprovação, foram excluídos instrumentos internacionais/pedidos de viagem/nomeações/autorizações pendentes e os rejeitados, uma vez que o fato destes permanecerem durante longo período transitando pelas comissões, sem serem submetidos à votação, representa, em muitos casos, uma forma de rejeição indireta, que evita o confronto e a exposição das votações.

\section{A DIVERGÊNCIA ENTRE OS PARTIDOS: PLATAFORMAS ELEITORAIS E A POSIÇÃo DOS PRINCIPAIS PARTIDOS MEXICANOS EM TEMAS DE POLÍTICA EXTERNA}

Sob a égide do regime autoritário do Partido Revolucionário Institucional (PRI), a política mexicana foi controlada pelo partido do governo ao longo de 70 anos, sem grande espaço para disputas partidárias. O processo decisório, altamente verticalizado e concentrado na mão do Presidente, retirou da arena política a disputa por imposição de políticas.

Esta situação se alterou com as transformações sofridas pelo regime político mexicano nos últimos 25 anos, motivadas pela abertura econômica e liberalização comercial, com especial destaque para a assinatura do NAFTA e pela terceira onda democrática $^{32}$ do final do século vinte, na qual se insere o México, o que deu espaço para o aumento do pluralismo e participação política ativa.

Os partidos políticos, antes alijados da disputa política de fato, embora formalmente fosse mantido o processo eleitoral, passaram então a atuar de maneira efetiva na arena política, concorrendo diretamente pela imposição de preferências para ações em âmbito interno e externo.

Como decorrência da visibilidade adquirida por algumas temáticas, as plataformas políticas dos partidos políticos mexicanos incorporam, em maior ou menor grau, diretrizes para a condução da política externa. Uma análise das plataformas para as

\footnotetext{
${ }^{32}$ A expressão "onda democrática" foi cunhada por Samuel Huntington, que a define como "um grupo de transições de regimes não democráticos para regimes democráticos que ocorre em um específico período de tempo e que supera significativamente o número de transições no sentido oposto" (Huntington, 1991).
} 
eleições de 2006 releva aspectos importantes sobre os pontos de convergência e divergência entre os partidos sobre as ações do México no plano internacional ${ }^{33}$.

As plataformas das eleições de 2006 são fruto da sedimentação dos projetos dos partidos para área internacional diante da importância doméstica adquirida pela política externa durante o governo Fox, o que justifica a sua escolha como parâmetro para medir o nível de divergência entre os partidos políticos mexicanos.

A acirrada disputada pela Presidência da República entre Felipe Calderón e Andrés Manuel Lopéz Obrador e a projeção de alguns temas internacionais forçaram os partidos mexicanos a apresentarem de maneira mais explícita seus projetos políticos a respeito da condução da política externa mexicana.

\subsection{Partido da AÇão NaCional (PAN)}

A Plataforma Eleitoral do PAN para as eleições de $2006^{34}$, embora não tivesse como foco a temática da política externa, apresentou um capítulo chamado "Democracia e Política Externa responsável", segundo o qual o grande desafio do México seria "conduzir uma política externa responsável, tendo como principal eixo o desenvolvimento humano sustentável”.

O México deveria exercer um papel de protagonista no cenário internacional e assumir sua "vocação latino-americana", conferindo tratamento especial para os países desta região. O país também deveria fazer alianças estratégicas com outras regiões, como a União Européia e Ásia do Pacífico, mas especialmente com os Estados Unidos e Canadá, em temas relacionados à segurança, prosperidade e imigração.

Entre os objetivos do PAN está a busca por uma "participação mais ativa na construção de um mundo mais humano", através da participação do México em organizações multilaterais, especificamente por intermédio de uma vaga no Conselho de Segurança das Nações Unidas pela segunda vez na administração do partido.

\footnotetext{
33 Além das coalizões listadas, participaram das eleições federais de 2006 o Partido Alternativa Socialdemocrata e Campesina e o Partido Nova Aliança, os quais, por serem partidos de menor expressão política, não tiveram a plataforma política analisada neste trabalho.

${ }^{34}$ Disponível em http://www.pan.org.mx/docs/Plataformaelectoral2006.pdf. Acesso em 05.03.2008.
} 
Algumas outras propostas enfatizam a necessidade de reforço do Serviço Externo do México (SEM), a criação de um Conselho Consultivo de Relações Internacionais para a Secretaria de Relações Exteriores (SRE), composto por cidadãos com expertise em política externa; promoção de bens e serviços do México no exterior, através da formalização de acordos para atrair investimentos; profissionalização das entidades governamentais encarregadas da defesa da segurança nacional, incluindo a negociação de acordos de fronteiras com os países vizinhos.

\subsection{CoALizÃo PARA O BEM de TODOS}

A "Coalición por el Bien de Todos" era formada pelo Partido da Revolução Democrática (PRD), pelo Partido do Trabalho (PT) e pelo Partido Convergência e lançou como candidato à presidência Andrés Manuel López Obrador.

Na plataforma eleitoral de $2006^{35}$, defendeu que o México não poderia se isolar da globalização, mas deveria tentar conter parte de seus efeitos negativos, especialmente, desigualdade econômica, danos ambientais, especulação financeira, conflitos sociais e concessões em termos de soberania. Para atingir tais objetivos, a Coalizão propunha o desenvolvimento de iniciativas multilaterais em favor da paz, democracia e desenvolvimento.

A Coalizão criticou a performance da administração de Vicente Fox no campo das relações internacionais e propôs "a estruturação de uma política externa que utilize a globalização como um instrumento em benefício do interesse nacional". Também considerou importante a revisão do capítulo de agricultura do NAFTA, a assinatura de um acordo de imigração com os Estados Unidos, a defesa da soberania do México no contexto da Aliança para a Segurança e Prosperidade (ASPAN) e o estreitamento das relações com países em desenvolvimento, como China, Índia e Brasil.

Trata-se, em síntese, da necessidade de conduzir uma política externa em conformidade com as prioridades internas do México. Por fim, propõe a fundação de um Conselho Nacional de Política Externa, uma reforma na lei mexicana sobre serviço

\footnotetext{
${ }^{35}$ Disponível em http://www.prd.org.mx/docs/PLAT_ELECTORAL_PTB.pdf. Aceso em 05.03.2008.
} 
exterior, a ratificação do mandato do Ministro das Relações Exteriores pelo Congresso e a resolução multilateral de problemas, com apoio do Executivo, Legislativo e Judiciário.

\subsection{AlianÇa PaRa O MÉXICO}

A coalizão partidária "Alianza para México" era composta pelo Partido Revolucionário Institucional (PRI) e pelo Partido Verde Ecologista do México (PVEM), tendo lançado como candidato à presidência Roberto Madrazo Pintado.

A plataforma da Aliança ${ }^{36}$ enfatizava a importância de defender a soberania do México e promover o desenvolvimento nacional. Em referência expressa ao período em que o PRI estava no comando do governo, um dos objetivos da Aliança era "reconquistar o prestígio diplomático internacional do México", desempenhando um papel ativo nas relações com América Latina, Caribe, Europa e a região da Ásia do Pacífico, a fim de aumentar o comércio e a cooperação. Também propõe a condução de negociações com os Estados Unidos e Canadá com relação à segurança da América do Norte.

A exemplo da plataforma dos demais partidos, a Aliança sugere uma reforma na lei de serviço exterior e uma atenção especial no desenvolvimento da proteção consular para imigrantes, a proteção dos direitos humanos, bem como a possível assinatura de um acordo migratório com os Estados Unidos.

È a única plataforma que considera importante o estreitamento das relações com os países da África e do Oriente Médio, e a cooperação no combate ao terrorismo e ao tráfico de drogas.

Existem alguns pontos de convergência nas plataformas das alianças de partidos que concorreram às eleições de 2006, tais como a criação de um corpo consultivo em matéria de política externa, a proteção das fronteiras mexicanas e a renovação do interesse por uma maior aproximação com a América Latina e pela diversificação das relações internacionais do México.

No entanto, o confronto entre as plataformas do PAN e da "Coalizão para o Bem de Todos", que polarizaram as eleições, torna clara a diferença entre dois projetos

\footnotetext{
${ }^{36}$ Disponível: http://www.ife.org.mx/documentos/PPP/plataformas2006/nueva_alianza_plataforma2006.pdf Acesso em 05.03.2008.
} 
distintos para a política externa do México. De um lado, o PAN defende a continuidade do projeto político de Fox, com o estreitamento das relações preferenciais com os Estados Unidos por meio da ASPAN e ampliação dos acordos comerciais com outros países estratégicos.

De outro, a "Coalizão para o Bem de Todos", que tinha como principal partido político o PRD, defendia uma política externa mais centrada nos interesses nacionais, preocupada com a defesa da soberania nas relações com os Estados Unidos e com a renegociação dos termos do NAFTA.

Para Dávila, “os partidos políticos não estão apenas interessados em ganhar as eleições, eles também desempenham um papel importante na estruturação da política externa. Uma prova deste fato seria que todos os partidos apresentam um órgão consultivo em matéria de política externa” (Dávila, 2006:10).

\section{A DIVERGÊNCIA ENTRE OS PODERES}

\subsection{O PODER DE VETO DO CONGRESSO MEXICANO}

\subsubsection{RATIFICAÇÃO DE TRATADOS INTERNACIONAIS E DE NOMEAÇÕES DIPLOMÁTICAS}

\subsubsection{PROCEDIMENTO PARA A APROVAÇÃO DE UM TRATADO INTERNACIONAL NO MÉXICO}

De acordo com o artigo 133 da Constituição Mexicana, as leis federais e os tratados são a lei suprema da nação, isto é, possuem a mesma hierarquia ${ }^{37}$. Como consequência, um tratado internacional pode modificar uma lei federal, como, por exemplo, o Código Penal Federal.

Existem ainda outros artigos na Constituição mexicana que fazem referência aos tratados e convenções internacionais, são eles: artigos 15, 18, 76, inciso I; 89, inciso X; 104, inciso I; 117, inciso I e 133.

\footnotetext{
${ }^{37}$ Existe, no entanto, um precedente da Suprema Corte De Justiça da Nação, de 28 de outubro de 1999 , reconhecendo que os tratados internacionais estariam acima das leis federais e em segundo plano em relação à Constituição Federal.
} 
$\mathrm{O}$ artigo 15 restringe as faculdades do Executivo e do Senado em celebrar tratados, ao vedar a assinatura de convenções internacionais que tenham por objeto a extradição de réus políticos ou de criminosos comuns que tenham assumido a condição de escravos no país onde cometeram o delito; bem como de tratados que alterem os direitos e garantias estabelecidos na Constituição para o homem e o cidadão.

Para a celebração de um tratado internacional no México, concorrem as vontades do Senado e do Presidente. As atribuições do Presidente estão definidas no artigo 89 da Constituição, ao passo que as faculdades do Senado estão descritas no artigo 76, fração I. Existe uma proibição expressa de que os Estados celebrem tratados internacionais (artigo 117).

A Lei Orgânica da Administração Pública Federal outorga à Secretaria de Relações Exteriores (SRE) a atribuição de intervir "em todo tipo de tratados, acordos ou convenções em que o país seja parte" (artigo 28), competência esta exercida por intermédio de sua Consultoria Jurídica, nos termos do artigo 11 do seu Regimento Interno.

O procedimento para a celebração de um tratado internacional no México abrange as seguintes etapas: negociação, redação e adoção de um texto; assinatura; aprovação interna; o consentimento do Estado em se vincular ao tratado e sua entrada em vigor.

Finda as negociações e uma vez assinado o tratado, a Secretaria de Relações Exteriores o envia para a apreciação do Senado da República, mas especificamente à Comissão Ordinária de Relações Exteriores ${ }^{38}$, para cumprir os trâmites previstos no título terceiro do capítulo quinto do regimento interno da Casa. Cada tratado é acompanhado de um memorando que contem seus antecedentes e explica o seu conteúdo, bem como as razões que motivaram sua celebração e os benefícios que dele se esperam.

Em alguns casos, os funcionários da Secretaria de Relações Exteriores que intervieram nas negociações se reúnem com os senadores para esclarecer alguma dúvida sobre o tratado.

${ }^{38}$ A comissão de relações exteriores foi criada no Senado mexicano no século passado; sua função principal consiste em realizar estudos e ditames relacionados aos assuntos exteriores que dizem respeito ao Senado em termos constitucionais. Ademais, promove ações interparlamentares de colaboração com representantes do Poder Legislativo de outros países. No período analisado neste trabalho, esta comissão era composta por cinco seguimentos: América do Norte; América Latina; Europa; Ásia e África; Organizações Internacionais e Assuntos Migratórios e de Proteção. 
O envio dos tratados ao Senado é feito por intermédio da Secretaria de Governo, em cumprimento ao disposto na Lei Orgânica da Administração Pública, já que é função desta Secretaria intermediar a relação entre os poderes da União.

Para tanto, o Secretário de Relações Exteriores envia um ofício ao Secretário de Governo, acompanhado de cópias certificadas do texto em espanhol do tratado e de cópias do memorando de antecedentes, no qual se requer, a fim de que seja dado cumprimento ao artigo 76, fração I, da Constituição, o encaminhamento ao Senado de uma cópia do tratado e uma cópia do memorando.

O processo legislativo mexicano se rege pela Constituição Política dos Estados Unidos Mexicanos, pela Lei Orgânica, pelo Regulamento para o Governo Interior do Congresso Geral dos Estados Unidos Mexicanos e pelos acordos parlamentares adotados pela maioria dos membros da Câmara.

Se, após apreciar o tratado, o Senado o aprova, baixa um decreto neste sentido, o qual é publicado no Diário Oficial da Federação. O decreto se limita a declarar que foi aprovado o tratado, já que não se publica o texto.

O decreto do Poder Executivo que autoriza a publicação no Diário Oficial do decreto emitido pelo Senado é assinado pelo Presidente e referendado pelo Secretário de Governo. Uma vez publicado no Diário Oficial o decreto de aprovação, o Poder Executivo já pode ratificar o tratado. Para tanto, é preparado o instrumento de ratificação, o qual é assinado pelo Presidente e referendado pelo Secretário de Relações Exteriores.

\subsubsection{AS VOTAÇÕES DE TRATADOS INTERNACIONAIS E DE NOMEAÇÕES DIPLOMÁTICAS NO SENADO MEXICANO}

No período de $1^{\circ}$ de setembro de 1994 a 31 de agosto de 2000 (LVI e LVII Legislaturas), foram apresentadas ao Congresso um total de 149 nomeações diplomáticas e a taxa de aprovação foi de $100 \%$, sem que nenhuma delas ficasse pendente.

Durante este período, as nomeações foram aprovadas em sua maioria por unanimidade, sem que houvesse grandes debates a respeito dos nomes indicados pelo governo de Ernesto Zedillo para ocupar cargos da diplomacia mexicana. 
No período de $1^{\circ}$ de setembro de 2000 a 31 de agosto de 2006, foram apresentadas ao Congresso um total de 185 nomeações diplomáticas, com igual de taxa de aprovação, isto é, $100 \%$.

Durante este período, o cenário se altera parcialmente. A despeito do êxito do Executivo, as nomeações do governo Fox não foram isentas de debates; algumas delas foram aprovadas com certa dificuldade. O caso mais emblemático foi a nomeação de Adolfo Aguilar Zinser como representante do México nas Nações Unidas. A resistência do PRI se devia ao fato de Aguilar não ser membro do Serviço Exterior Mexicano. Em nomeações dessa natureza, com caráter eminentemente político e não envolvendo membros de carreira, em muitos casos os senadores do PRD e do PRI votaram contra ou mesmo se abstiveram de votar.

Tabela 20 - Nomeacões diplomáticas submetidas à votação

\begin{tabular}{|c|c|c|c|c|c|}
\hline Legislatura & Apresentadas & Aprovadas & Pendentes & Rejeitadas & $\begin{array}{c}\text { Porcentagem de } \\
\text { aprovação }\end{array}$ \\
\hline LVI & 69 & 69 & 0 & 0 & $100 \%$ \\
\hline LVII & 80 & 80 & 0 & 0 & $100 \%$ \\
\hline LVIII & 106 & 106 & 0 & 0 & $100 \%$ \\
\hline LXIX & 79 & 79 & 0 & 0 & $100 \%$ \\
\hline
\end{tabular}

Fontes: Tabela elaborada pela autora a partir de dados do Sistema de Informação Legislativa do Governo Mexicano e dos Diários de Debates da Câmara dos Deputados e Senado mexicanos

No tocante à ratificação de instrumentos internacionais, a porcentagem de aprovação também foi elevada.

No período de $1^{\circ}$ de setembro de 1994 a 31 de agosto de 2000, foram encaminhados ao Senado mexicano um total de 260 instrumentos internacionais para ratificação. Dos 260 tratados, 252 foram submetidos à votação, com taxa de aprovação de $100 \%$, e 8 tratados apresentados na LVII Legislatura ainda se encontram pendentes nas comissões para a elaboração de ditame.

Os instrumentos internacionais pendentes são: a) tratado para a unificação de certas regras de transporte aéreo internacional; b) tratado sobre as agências de emprego privadas, firmado na LXXXV reunião da Conferência Geral da OIT, 1997; c) recomendação sobre as agências de emprego privadas, firmada na LXXXV reunião da 
Conferência Geral da OIT, 1997; d) tratado sobre trabalho a domicílio; e) recomendação sobre trabalho a domicílio; f) tratado sobre segurança e saúde nas minas; g) recomendação sobre segurança e saúde nas minas; h) decisão do conselho conjunto do acordo interno sobre comércio e questões relacionadas entre México e a Comunidade Européia.

No período de $1^{\circ}$ de setembro de 2000 a 31 de agosto de 2006, foram encaminhados ao Senado mexicano um total de 222 instrumentos internacionais. Destes, 205 foram submetidos à votação e 7 foram rejeitados; 5 deles estão pendentes nas comissões.

Os instrumentos internacionais que não foram aprovados são: a) acordo marco de cooperação financeira com o Banco Europeu de Investimentos; b) tratado relativo à segurança e saúde na agricultura, 2001; c) convênio sobre documentos de identidade de "gente do mar"; d) protocolo de 1996 relativo ao tratado sobre normas mínimas de marinha mercante; e) tratado relativo às horas de trabalho a bordo; f) tratado relativo à contratação e colocação da gente do mar; g) tratado relativo à inspeção das condições de vida da gente do mar, 2002.

O acordo marco de cooperação financeira com o Banco Europeu, subscrito em 13 de novembro de 2003 em Luxemburgo, compreendia um conjunto de ações de cooperação financeira a serem realizadas no México. O tratado recebeu ditame negativo das Comissões Unidas de Relações Exteriores, África e Europa e Fazenda e Crédito Público, responsáveis pelo seu relato.

As comissões relatoras consideraram que o acordo continha disposições que dariam ao Banco Europeu de Investimentos um marco jurídico de incerteza em relação aos empréstimos que outorga e as operações comerciais que realiza. Consideraram ainda que ao ser o Banco Europeu de Investimentos, juntamente com os Estados europeus, quem decidiriam quais projetos seriam financiados, seria perdido o objetivo de obter o financiamento para projetos de interesse do Estado mexicano. O sentido do acordo se desvirtuaria com a aprovação de financiamentos que não trouxessem risco à rentabilidade financeira, sem considerar o benefício social à população.

A questão fiscal também foi colocada, uma vez que o Banco e seus intermediários estariam isentos do pagamento de impostos federais diretos em relação às rendas e ativos 
que utilizassem. O ditame negativo proposto pelas Comissões foi aprovado pelo Senado com 65 votos a favor, 6 votos contra e 12 abstenções. Os votos contra e 11 das abstenções partiram de senadores do PAN; 1 senador do PRI se absteve de votar.

$\mathrm{O}$ Convênio $\mathrm{n}^{\mathrm{o}} 184$ relativo à segurança e saúde na agricultura e sua recomendação nº 192 foram adotados em 21 de junho de 2001, em Genebra, Suíça. O tratado recebeu ditame negativo das Comissões Unidas de Relações Exteriores, Organizações Internacionais, Saúde e Segurança do Trabalho por contrariar a legislação trabalhista mexicana. Entre os pontos destacados pela comissão como contrários ao ordenamento jurídico interno, estavam a possibilidade de instituições privadas realizarem funções de inspeção das condições gerais de trabalho e a autorização para a suspensão dos trabalhos pelos agricultores em caso de risco eminente e grave à sua segurança e saúde.

O Convênio também proibia o trabalho em lugares de risco na agricultura a menores de 18 anos, quando a legislação trabalhista mexicana fixa a idade mínima de 14 anos. O ditame negativo foi submetido à votação econômica e aprovado por unanimidade; a proposta de retorno à comissão de origem foi rejeitada.

O Convênio sobre documentos de identidade de "gente do mar", assinado em 13 de junho de 2003, em Genebra, Suíça, tinha por objetivo agilizar a entrada de "gente do mar" no território dos países signatários, quando esta entrada tivesse por finalidade o gozo de uma permissão para desembarque em terra, o trânsito e reembarque em outro navio ou a repatriação.

As Comissões Unidas de Relações Exteriores, Organizações Internacionais e Trabalho e Previdência Social emitiram ditame em sentido negativo por considerarem que algumas disposições do tratado contrariavam a legislação nacional, especialmente o conceito de "gente do mar" e o documento de identificação proposto, muito distinto do Documento de Identidade Marítima vigente no México. O ditame negativo foi aprovado por unanimidade com 84 votos.

Os outros quatro instrumentos internacionais rejeitados se referem a Convênios da Organização Internacional do Trabalho relacionados à "gente do mar", adotados em 22 de outubro de 1996, em Genebra, Suíça. A justificativa para a rejeição residiu na incompatibilidade com a legislação nacional mexicana. 
O Convênio relativo à contratação e colocação de "gente do mar" recebeu ditame negativo das Comissões Unidas de Relações Internacionais, Organizações Internacionais, Marinha e Trabalho e Previdência Social, em virtude dos seguintes fatores: a) inexistência na legislação mexicana de agências de contratação de "gente do mar"; b) previsão de que não deveria ser estimulada a proliferação de serviços particulares, o que implicaria em violação à livre iniciativa; c) imposição aos serviços de colocação de obrigações que não encontram amparo na legislação mexicana, como a de informar a "gente do mar" sobre seus direitos e deveres.

O Convênio relativo às horas de trabalho a bordo tinha por objeto regular o limite de horas de trabalho e o mínimo de horas de descanso da "gente do mar". Recebeu ditame negativo das comissões relatoras, pois seria aplicado a trabalhadores de determinados tipos de embarcação e estabelecia um mínimo de horas de descanso inferior ao regulado pela Lei Federal de Trabalho mexicana e uma máximo de horas superior.

O Convênio relativo à inspeção de condições de vida da "gente do mar" também recebeu ditame negativo das comissões relatoras por violar as normas internas quanto à competência para realizar inspeções desta natureza.

Por fim, o Protocolo de 1996 relativo ao tratado sobre normas mínimas de marinha mercante visava à criação de normas para proteger a vida a bordo, tais como a existência de um regime adequado de seguridade social, a regulação de horas de trabalho e a implementação das normas de segurança.

As comissões relatoras consideraram o tratado "alheio à legislação nacional, às políticas internacionais do país, por ser unilateral, implicar em renúncia à soberania e regular matérias não contempladas na legislação interna" ${ }^{\$ 9}$.

Os instrumentos internacionais pendentes ${ }^{40}$ são: a) acordo com a Alemanha sobre cooperação financeira, 2006 (rejeitado na comissão de origem); b) convênio sobre documentos de identidade das pessoas do mar (rejeitado na comissão de origem) ${ }^{41}$;c)

\footnotetext{
${ }^{39}$ Gazeta Parlamentar do Senado mexicano de 31 de outubro de 2002, p. 185, disponível em www.senado.gob.mx. Acesso em 16.10.2008.

${ }^{40}$ Os instrumentos internacionais pendentes abrangem tanto aqueles que permanecem em suas comissões de origem para elaboração de ditame, como aqueles que foram a plenário e foi determinado o retorno à comissão de origem.

${ }^{41}$ Os dois primeiros instrumentos internacionais mencionados, o acordo sobre cooperação financeira com a Alemanha e o convênio sobre documentos de identidade de pessoas do mar, receberam ditame negativo na comissão de origem, mas ainda não foram à votação em plenário. Os dados sobre a votação no interior das
} 
protocolo 2002 do convênio sobre segurança e saúde dos trabalhadores de 1981; d) tratado com os Estados Unidos sobre seguridade social, 2004; e) convenção sobre a proteção dos direitos humanos e da dignidade da pessoa humana na aplicação da biologia, medicina e clonagem; f) protocolo adicional à convenção sobre a proteção dos direitos humanos e da dignidade da pessoa humana na aplicação da biologia, medicina e clonagem.

\section{Tabela 21 - Instrumentos Internacionais}

\begin{tabular}{|c|c|c|c|c|c|}
\hline Legislatura & Apresentados & Aprovados & Pendentes & Rejeitados & $\begin{array}{c}\text { Porcentagem de } \\
\text { aprovação }\end{array}$ \\
\hline LVI & 104 & 104 & 0 & 0 & $100 \%$ \\
\hline LVII & 156 & 148 & 8 & 0 & $94,87 \%$ \\
\hline LVIII & 119 & 111 & 2 & 6 & $93,27 \%$ \\
\hline LIX & 103 & 99 & 3 & 1 & $96,11 \%$ \\
\hline
\end{tabular}

Fontes: Tabela elaborada pela autora a partir de dados do Sistema de Informação Legislativa do Governo Mexicano e dos Diários de Debates da Câmara dos Deputados e Senado mexicanos

Os tratados submetidos à aprovação versavam sobre temáticas variadas. Comércio internacional, cooperação econômica e cooperação financeira foram objeto de parcela significativa dos instrumentos assinados, cerca de $16 \%$ do total, confirmando o perfil do México de ser um dos países com o maior número de acordos de livre comércio celebrados.

Entretanto, de uma maneira geral, predominaram no período analisado os acordos internacionais de natureza eminentemente cooperativa, os quais, em razão de seu reduzido potencial de gerar efeitos distributivos, tendem a receber apoio dos congressistas. São exemplos de acordos desta natureza os instrumentos internacionais sobre cooperação nas áreas jurídica, de educação e cultura, ciência e tecnologia, turismo, direitos humanos e meio-ambiente, que correspondem a mais de $50 \%$ do total de tratados apresentados ao Legislativo.

Outros temas como saúde, energia, comunicação, transporte, seguridade social e legislação trabalhista também foram objeto de ajuste internacional.

comissões não estão disponíveis nos sistemas de informação do governo mexicano, o que dificulta uma investigação mais aprofundada sobre os motivos das rejeições. 
Velázquez (2007) observa, com precisão, que os temas de segurança estiveram praticamente ausentes nos tratados bilaterais celebrados pelo governo Fox. As parcerias que foram firmadas com os Estados Unidos, como a ASPAN, não foram submetidas à aprovação pelo Senado. O mesmo argumento é válido para o governo Zedillo.

Ao longo do período analisado, foram assinados apenas 10 tratados internacionais com a temática de segurança, são eles: a) convênio para a repressão de atos de terrorismo nuclear (2005); b) acordo com a organização para a proscrição de armas nucleares na América Latina e Caribe (2003); c) convenção interamericana contra o terrorismo e sua declaração interpretativa (2002); d) emenda ao artigo I da Convenção sobre a proibição de uso de determinadas armas convencionais (2002); e) protocolo contra a fabricação e tráfico ilícitos de armas de fogo (2002); f) tratado de proibição completa de testes nucleares da Organização das Nações Unidas (1999); g) convenção interamericana contra a fabricação e tráfico ilícito de armas de fogo, munições, explosivos e outros materiais relacionados (1998); h) convenção sobre a proibição de emprego, armazenamento, produção e transferência de minas contra pessoas (1998); i) protocolo adicional à convenção sobre proibição de certas armas convencionais consideradas nocivas ou de efeitos indiscriminados (1997); j) convenção das Nações Unidas sobre segurança nuclear.

Outra questão sensível, a temática da imigração para os Estados Unidos, presente nas plataformas dos partidos e também nas campanhas presidenciais, não foi objeto de ajuste internacional no decorrer dos 12 anos analisados, embora o Executivo tenha sido exortado em diversas oportunidades pelo Congresso a adotar ações mais incisivas em favor dos imigrantes mexicanos.

Os tratados internacionais assinados em matéria de imigração se referem à constituição da Organização Internacional da Imigração e ao estabelecimento de um escritório de representação no México (2001 e 2004), e à convenção internacional de proteção aos trabalhadores imigrantes e suas famílias (1998).

O gráfico abaixo ilustra a porcentagem de tratados internacionais assinados sobre cada temática nas quatro legislaturas estudadas: 


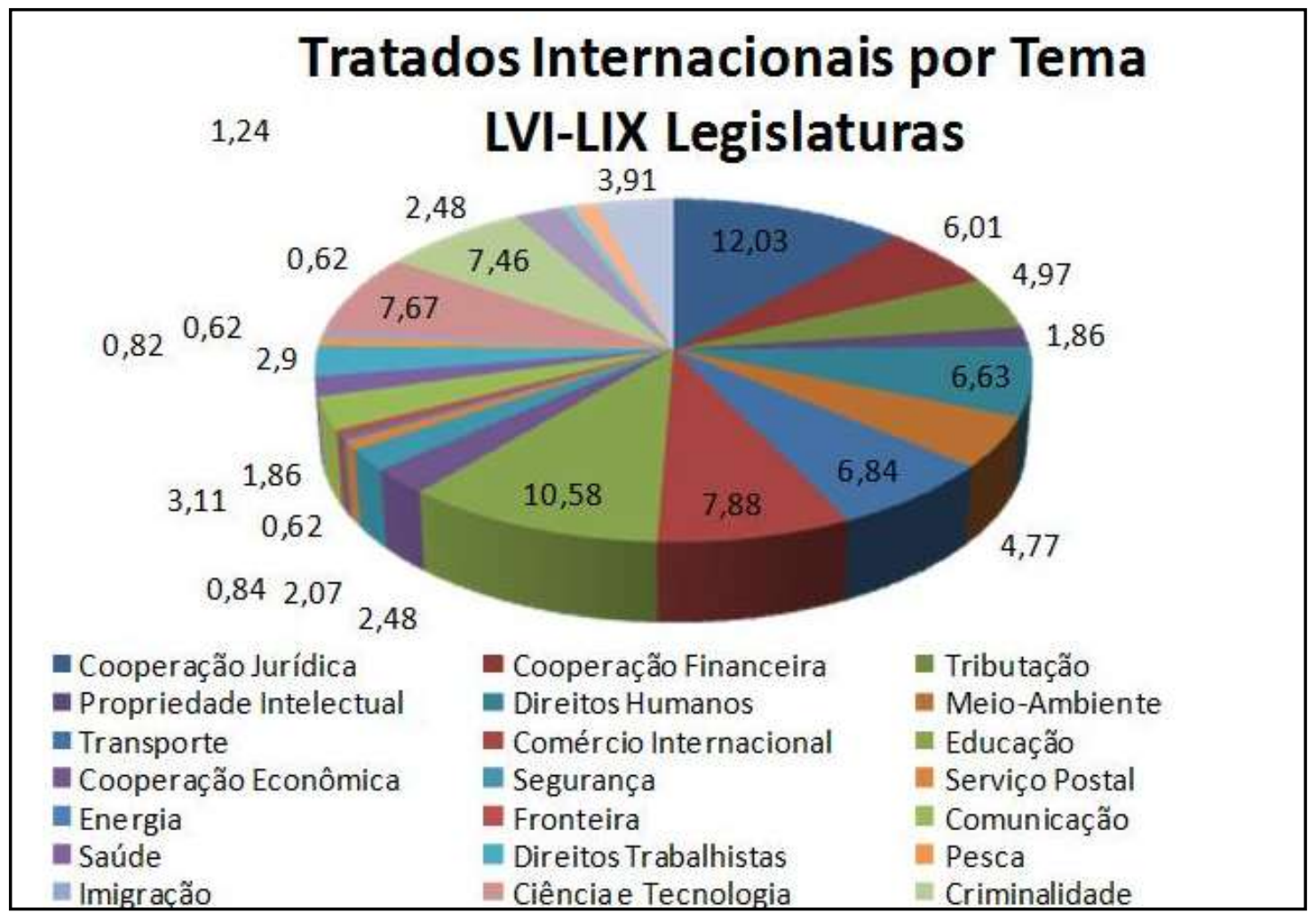

A análise das votações dos instrumentos internacionais no Senado mexicano revela que, ao longo do período estudado (1994-2006), de um total de 473 tratados aprovados, apenas 26 deles receberam votos contrários. As votações por unanimidade são a regra e, quando existem votos contrários, na maior parte das vezes, estes não foram capazes de pôr em risco a aprovação do instrumento internacional.

A tabela abaixo apresenta uma lista dos instrumentos internacionais em cuja ratificação houve ao menos um voto contrário, com suas respectivas votações, a fim de verificar quais temas foram capazes de dividir a opinião dos senadores mexicanos: 
Tabela 22 - Instrumentos Internacionais não aprovados por unanimidade

\begin{tabular}{|c|c|c|c|c|c|c|}
\hline $\begin{array}{l}\text { Instrumento } \\
\text { internacional }\end{array}$ & Tema & $\begin{array}{c}\text { Data de } \\
\text { apresentação }\end{array}$ & $\begin{array}{c}\text { Aprovação } \\
\text { pelo pleno }\end{array}$ & $\begin{array}{l}\text { Resultado da } \\
\text { votação }\end{array}$ & $\begin{array}{l}\text { Legisla } \\
\text { tura }\end{array}$ & $\begin{array}{c}\text { Efeitos } \\
\text { Distributi } \\
\text { vos }\end{array}$ \\
\hline $\begin{array}{l}\text { Modificação ao } \\
\text { anexo } 401 \text { do } \\
\text { NAFTA, } 2006\end{array}$ & Economia & $30 / 03 / 2006$ & $26 / 04 / 06$ & $\begin{array}{c}76 \text { votos a favor } \\
4 \text { votos contra de } \\
\text { membros do PRD } \\
1 \text { abstenção do PRD }\end{array}$ & LIX & SIM \\
\hline $\begin{array}{l}\text { Modificações ao } \\
\text { anexo } 401 \text { do } \\
\text { NAFTA, } \\
\text { acompanhadas do } \\
\text { informe do artigo } \\
9^{\circ} \text { da Lei sobre } \\
\text { aprovação dos } \\
\text { tratados em matéria } \\
\text { econômica }\end{array}$ & Economia & $23 / 11 / 2004$ & $16 / 03 / 05$ & $\begin{array}{c}75 \text { votos a favor } \\
2 \text { votos contra do } \\
\text { PRD } \\
4 \text { abstenções do PRD }\end{array}$ & LIX & SIM \\
\hline $\begin{array}{c}\text { Acordo para o } \\
\text { fomento de } \\
\text { investimentos entre } \\
\text { México e EUA }\end{array}$ & $\begin{array}{l}\text { Economia, } \\
\text { investimen } \\
\text { tos }\end{array}$ & $16 / 10 / 2003$ & $27 / 04 / 04$ & $\begin{array}{c}72 \text { votos a favor } \\
6 \text { votos contra } \\
0 \text { abstenções }\end{array}$ & LIX & SIM \\
\hline $\begin{array}{l}\text { Estatuto de Roma } \\
\text { do Tribunal Penal } \\
\text { Internacional }\end{array}$ & $\begin{array}{c}\text { Direitos } \\
\text { Humanos }\end{array}$ & 28/08/2002 & $21 / 06 / 05$ & $\begin{array}{c}78 \text { votos a favor } \\
1 \text { voto contra do PRI } \\
0 \text { abstenções }\end{array}$ & LVIII & NÃO \\
\hline $\begin{array}{l}\text { Acordo com a } \\
\text { Coréia para a } \\
\text { promoção e } \\
\text { proteção de } \\
\text { investimentos } \\
\text { recíprocos }\end{array}$ & $\begin{array}{l}\text { Economia, } \\
\text { investimen } \\
\text { tos }\end{array}$ & $24 / 04 / 2001$ & $16 / 04 / 02$ & $\begin{array}{l}98 \text { votos a favor } \\
1 \text { voto contra } \\
0 \text { abstenções }\end{array}$ & LVIII & SIM \\
\hline $\begin{array}{l}\text { Acordo com a } \\
\text { Suécia sobre a } \\
\text { promoção e } \\
\text { proteção de } \\
\text { investimentos }\end{array}$ & $\begin{array}{l}\text { Economia, } \\
\text { investimen } \\
\text { tos }\end{array}$ & $16 / 11 / 2000$ & 03/04/01 & $\begin{array}{c}78 \text { votos a favor } \\
2 \text { votos contra } \\
1 \text { abstenção }\end{array}$ & LVIII & SIM \\
\hline $\begin{array}{c}\text { Acordo com a } \\
\text { Dinamarca para a } \\
\text { promoção e } \\
\text { proteção de } \\
\text { investimentos }\end{array}$ & $\begin{array}{l}\text { Economia, } \\
\text { investimen } \\
\text { tos }\end{array}$ & $24 / 04 / 2000$ & $28 / 04 / 00$ & $\begin{array}{l}65 \text { votos a favor } \\
10 \text { votos contra } \\
1 \text { abstenção }\end{array}$ & LVII & SIM \\
\hline $\begin{array}{l}\text { Decisão sobre } \\
\text { comércio do } \\
\text { conselho conjunto } \\
\text { do acordo com a } \\
\text { EU }\end{array}$ & $\begin{array}{c}\text { Comércio } \\
\text { internacio } \\
\text { nal }\end{array}$ & 01/03/2000 & $20 / 03 / 00$ & $\begin{array}{l}89 \text { votos a favor } \\
11 \text { votos contra } \\
2 \text { abstenções }\end{array}$ & LVII & SIM \\
\hline
\end{tabular}




\begin{tabular}{|c|c|c|c|c|c|c|}
\hline $\begin{array}{c}\text { Decisão do } \\
\text { conselho conjunto } \\
\text { do acordo com a } \\
\text { EU }\end{array}$ & $\begin{array}{c}\text { Comércio } \\
\text { internacio } \\
\text { nal }\end{array}$ & $01 / 03 / 2000$ & $20 / 03 / 00$ & $\begin{array}{c}89 \text { votos a favor } \\
11 \text { votos contra } \\
2 \text { abstenções }\end{array}$ & LVII & SIM \\
\hline $\begin{array}{l}\text { Acordo de } \\
\text { Associaçãao } \\
\text { Econômica, } \\
\text { Concertação } \\
\text { Política e } \\
\text { cooperação com a } \\
\text { Comunidade } \\
\text { Européia }\end{array}$ & $\begin{array}{c}\text { Comércio } \\
\text { internacio } \\
\text { nal }\end{array}$ & $23 / 02 / 00$ & $20 / 03 / 00$ & $\begin{array}{c}89 \text { votos a favor } \\
11 \text { votos contra } \\
2 \text { abstenções } \\
\text { Em relação aos } \\
\text { artigos 1, título I, } \\
\text { título II e Título VI e } \\
\text { inciso b do artigo 15, } \\
\text { título VI } \\
101 \text { votos a favor e } \\
0 \text { contra } \\
\text { demais artigos } \\
90 \text { votos a favor } \\
11 \text { votos contra } \\
\text { 0abstenções }\end{array}$ & LVII & SIM \\
\hline $\begin{array}{l}\text { Acordo com } \\
\text { Portugal para a } \\
\text { promoção e } \\
\text { proteção de } \\
\text { investimentos }\end{array}$ & $\begin{array}{l}\text { Economia, } \\
\text { investimen } \\
\text { tos }\end{array}$ & $05 / 01 / 00$ & $17 / 04 / 00$ & $\begin{array}{c}64 \text { votos a favor } \\
9 \text { votos contra } \\
0 \text { abstenções }\end{array}$ & LVII & SIM \\
\hline $\begin{array}{l}\text { Acordo com a } \\
\text { Itália para a } \\
\text { promoção e } \\
\text { proteção de } \\
\text { investimentos }\end{array}$ & $\begin{array}{l}\text { Economia, } \\
\text { investimen } \\
\text { tos }\end{array}$ & $02 / 12 / 99$ & $17 / 04 / 00$ & $\begin{array}{c}64 \text { votos a favor } \\
9 \text { votos contra } \\
0 \text { abstenções }\end{array}$ & LVII & SIM \\
\hline $\begin{array}{l}\text { Acordo com o } \\
\text { Uruguai para a } \\
\text { promoção e } \\
\text { proteção de } \\
\text { investimentos }\end{array}$ & $\begin{array}{l}\text { Economia, } \\
\text { investimen } \\
\text { tos }\end{array}$ & 08/09/99 & $11 / 12 / 99$ & $\begin{array}{c}76 \text { votos a favor } \\
9 \text { votos contra } \\
4 \text { abstenções }\end{array}$ & LVII & \\
\hline $\begin{array}{c}\text { Resolução que } \\
\text { modifica o } \\
\text { convênio } \\
\text { constitutivo do } \\
\text { Banco } \\
\text { Centroamericano } \\
\text { de Integração } \\
\text { Econômica }\end{array}$ & Economia & $08 / 04 / 99$ & $26 / 04 / 99$ & $\begin{array}{c}96 \text { votos a favor } \\
8 \text { votos contra } \\
0 \text { abstenções }\end{array}$ & LVII & SIM \\
\hline $\begin{array}{l}\text { Acordo com a } \\
\text { Finlândia para a } \\
\text { promoção e } \\
\text { proteção de } \\
\text { investimentos }\end{array}$ & $\begin{array}{l}\text { Economia, } \\
\text { investimen } \\
\text { tos }\end{array}$ & 29/03/99 & $17 / 04 / 00$ & $\begin{array}{c}64 \text { votos a favor } \\
9 \text { votos contra } \\
0 \text { abstenções }\end{array}$ & LVII & SIM \\
\hline
\end{tabular}




\begin{tabular}{|c|c|c|c|c|c|c|}
\hline $\begin{array}{l}\text { Acordo com a } \\
\text { França para a } \\
\text { promoção e } \\
\text { proteção de } \\
\text { investimentos }\end{array}$ & $\begin{array}{l}\text { Economia, } \\
\text { investimen } \\
\text { tos }\end{array}$ & $01 / 12 / 98$ & $17 / 04 / 00$ & $\begin{array}{c}64 \text { votos a favor } \\
9 \text { votos contra } \\
0 \text { abstenções }\end{array}$ & LVII & SIM \\
\hline $\begin{array}{l}\text { Acordo com a } \\
\text { Áustria para a } \\
\text { promoção e } \\
\text { proteção de } \\
\text { investimentos }\end{array}$ & $\begin{array}{c}\text { Economia, } \\
\text { investimen } \\
\text { tos }\end{array}$ & $09 / 09 / 98$ & $14 / 12 / 98$ & $\begin{array}{c}65 \text { votos a favor } \\
13 \text { votos contra } \\
25 \text { abstenções }\end{array}$ & LVII & SIM \\
\hline $\begin{array}{l}\text { Acordo com os } \\
\text { Países Baixos para } \\
\text { a promoção e } \\
\text { proteção de } \\
\text { investimentos }\end{array}$ & $\begin{array}{c}\text { Economia, } \\
\text { investimen } \\
\text { tos }\end{array}$ & $09 / 09 / 98$ & $14 / 12 / 98$ & $\begin{array}{c}65 \text { votos a favor } \\
13 \text { votos contra } \\
25 \text { abstenções }\end{array}$ & LVII & SIM \\
\hline $\begin{array}{c}\text { Emenda à } \\
\text { Constituição da } \\
\text { Organização } \\
\text { Internacional do } \\
\text { Trabalho }\end{array}$ & $\begin{array}{l}\text { Legislação } \\
\text { trabalhista }\end{array}$ & $13 / 11 / 97$ & $13 / 12 / 97$ & $\begin{array}{c}94 \text { votos a favor } \\
1 \text { voto contra } \\
1 \text { abstenção }\end{array}$ & LVII & NÃO \\
\hline $\begin{array}{c}\text { Convênio de } \\
\text { cooperação técnica } \\
\text { e científica com a } \\
\text { Ucrânia }\end{array}$ & $\begin{array}{l}\text { Ciência e } \\
\text { tecnologia }\end{array}$ & $04 / 11 / 97$ & $13 / 12 / 97$ & $\begin{array}{c}94 \text { votos a favor } \\
1 \text { voto contra } \\
1 \text { abstenção }\end{array}$ & LVII & NÃO \\
\hline $\begin{array}{l}\text { Tratado sobre } \\
\text { transporte aéreo } \\
\text { com o Chile }\end{array}$ & Transporte & & $22 / 04 / 97$ & $\begin{array}{l}99 \text { votos a favor } \\
1 \text { voto contra } \\
0 \text { abstenções }\end{array}$ & LVI & NÃO \\
\hline $\begin{array}{l}\text { Emendas ao } \\
\text { Convênio } \\
\text { Constitutivo da } \\
\text { Organização } \\
\text { Internacional } \\
\text { Marítima }\end{array}$ & Transporte & & $22 / 04 / 97$ & $\begin{array}{l}99 \text { votos a favor } \\
1 \text { voto contra } \\
0 \text { abstenções }\end{array}$ & LVI & NÃO \\
\hline $\begin{array}{c}\text { Anexo V ao } \\
\text { Protocolo de } 1978 \\
\text { relativo à } \\
\text { preservação contra } \\
\text { a contaminação } \\
\text { pelos barcos } \\
\text { pesqueiros }\end{array}$ & $\begin{array}{l}\text { Meio- } \\
\text { ambiente }\end{array}$ & & $22 / 04 / 97$ & $\begin{array}{l}99 \text { votos a favor } \\
1 \text { voto contra } \\
0 \text { abstenções }\end{array}$ & LVI & NÃO \\
\hline $\begin{array}{l}\text { Modificação do } \\
\text { convênio de } \\
\text { transportes aéreos } \\
\text { com o Canadá }\end{array}$ & Transporte & & $22 / 04 / 97$ & $\begin{array}{l}99 \text { votos a favor } \\
1 \text { voto contra } \\
0 \text { abstenções }\end{array}$ & LVI & NÃO \\
\hline
\end{tabular}




\begin{tabular}{|c|l|l|c|c|c|c|}
\hline $\begin{array}{c}\text { Tratado sobre } \\
\text { transporte aéreo } \\
\text { com Luxemburgo }\end{array}$ & Transporte & $25 / 04 / 96$ & $\begin{array}{c}101 \text { votos a favor } \\
1 \text { voto contra } \\
0 \text { abstenções }\end{array}$ & LVI & NÃO \\
\hline $\begin{array}{c}\text { Convênio de } \\
\text { transporte aéreo } \\
\text { com a Áustria }\end{array}$ & Transporte & & $26 / 10 / 95$ & $\begin{array}{c}101 \text { votos a favor } \\
1 \text { voto contra } \\
0 \text { abstenções }\end{array}$ & LVI & NÃO \\
\hline
\end{tabular}

A análise da tabela acima vai ao encontro do diagnóstico formulado por Fabiano dos Santos e Maria Regina Soares de Lima (2001) de que temas com efeitos distributivos tendem a gerar maior mobilização do Congresso. Dos 26 instrumentos internacionais constantes da tabela, 17 se referem a temas com efeitos distributivos.

Este dado ganha maior expressividade quando levamos em conta que, nos temas sem efeitos distributivos, temos apenas um voto em sentido contrário à aprovação dos $\operatorname{tratados}^{42}$, refletindo uma posição isolada de um dos senadores, conforme se pode depreender da análise do Diário de Debates, e não uma real divergência de posicionamento no interior do Senado mexicano.

A exceção a este quadro é o Tratado de Roma que instituiu o Tribunal Penal Internacional, cuja ratificação, mesmo sem efeitos distributivos concretos, gerou grande debate entre os congressistas mexicanos, por sua incompatibilidade com alguns dispositivos da legislação nacional. A solução encontrada para pacificar as divergências foi a incorporação pelo Senado de uma nova atribuição: a de aprovar o reconhecimento pelo Executivo da competência do Tribunal Penal Internacional em cada caso.

No mais, os tratados em que houve maior divergência entre os congressistas são justamente aqueles com temática de efeitos distributivos. Todos eles foram levados à discussão em plenário, durante a qual os diversos grupos partidários do Senado mexicano e mesmo senadores isolados puderam expor com clareza seu posicionamento.

As modificações ao Anexo 401 do NAFTA tinham por objeto a flexibilização das regras de origem do Tratado de Livre Comércio da América do Norte e receberam votos contrários de membros do PRD por considerá-las nocivas à indústria nacional.

\footnotetext{
${ }^{42}$ Em que pese a discutível relevância de votações com apenas um voto divergente para a análise desenvolvida, optamos por incluir esses tratados na tabela apenas para manter fidelidade ao recorte de dados, que inclui todos os tratados que não foram aprovados por unanimidade.
} 
O acordo de investimentos com os Estados Unidos também recebeu oposição dos senadores do PRD, que o consideraram parte da chamada "Associação para a Prosperidade". Os perredistas se mostraram contrários ao modelo econômico adotado pelo México nos últimos 25 anos e viam o acordo como um mecanismo de proteção aos investidores americanos e não como uma forma de alavancar os investimentos no país. A bancada do PRI saiu em defesa do acordo, ressaltando que todo investimento estrangeiro será sempre bem vindo no México.

Além do tratado com os Estados Unidos, outros 8 acordos para a promoção e proteção de investimentos recíprocos foram submetidos à votação durante as legislaturas analisadas, tendo como parceiros países da Europa, Uruguai e a Coréia do Sul. Os acordos, conhecidos como APRI’s (abreviação de acordo para a proteção recíproca de investimentos), receberam forte oposição da bancada do PRD, que votou em bloco contra suas ratificações.

Os argumentos levantados pelo PRD enfatizavam que os acordos, de índole neocolonial, estabeleciam um regime especial para os investidores estrangeiros que diminuía a soberania do país em matéria de investimentos e regulação. Para os perredistas, assim como o capítulo 11 do NAFTA, os APRI's acentuavam os aspectos mais negativos da liberalização irrestrita de investimentos: crises financeiras, fragilidade e instabilidade no processo de crescimento, desnacionalização e desarticulação da planta produtiva e concentração de renda.

Os APRI's foram aprovados com o apoio das bancadas do PRI e do PAN, que votaram em bloco a favor dos acordos, sob o argumento de que o México precisava de investimentos estrangeiros para desenvolver a sua economia e solidificar seu processo de abertura econômica.

As decisões do Conselho Europeu, que unidas formavam um verdadeiro tratado comercial com os países da Europa, foram interpretadas pelo PRD como uma releitura do NAFTA, caracterizada pela assimetria nas negociações. Mais uma vez, PRI e PAN saíram em defesa dos acordos e garantiram sua aprovação.

Por fim, o instrumento de modificação do tratado constitutivo do Banco Centroamericano de Integração Econômica sofreu oposição dos senadores pela existência de uma cláusula prevendo a possibilidade de alterações no acordo sem a aprovação do 
Senado. Ademais, um temor de possível dolarização da economia, já que o banco só aceita dólares norte-americanos para cumprimento das obrigações, foi invocado pelo PRD para sustentar a sua rejeição.

A bancada do PAN se absteve da votação por considerar que o tema não fora suficientemente discutido. A votação favorável do PRI e dos demais partidos do Senado garantiu a aprovação do instrumento, a despeito da oposição do PRD.

Conforme se pode observar, ao longo dos governos analisados, o Partido da Revolução Democrática ${ }^{43}$ estruturou a oposição no Senado mexicano contra o processo de ampla abertura econômica do país, capitaneado pela assinatura dos APRI's. Contudo, o pequeno número de senadores eleitos pelo partido nas Legislaturas LVI, LVII, LVIII, LIX impediu que seus votos pudessem pôr em risco a aprovação dos tratados. Os votos dos senadores do PRI e do PAN foram suficientes para garantir a aprovação de todos os tratados com efeitos distributivos.

O fato da maior parte dos tratados com efeitos distributivos terem sido aprovados pelo Senado mexicano não retira a força do argumento de Fabiano dos Santos e Maria Regina Soares de Lima, uma vez que foram estes que se mostraram capazes de gerar debate e mobilização no interior do Congresso, revelando divergência de posição entre os partidos.

No caso dos tratados rejeitados pelo Senado, o único instrumento internacional cuja votação gerou divergências no interior da Câmara Alta foi o acordo com o Banco Europeu de Investimentos, também com efeitos distributivos. Muito embora as comissões relatoras tenham elaborado ditame para a rejeição do tratado, os membros do PAN saíram em defesa do Executivo e votaram contra o seu rechaço.

Os demais tratados que foram rejeitados receberam votação unânime dos senadores mexicanos, os quais seguiram o entendimento das comissões relatoras de que os instrumentos internacionais afrontavam disposições da legislação interna. Muito mais do que possíveis efeitos distributivos dos tratados, o fator determinante das rejeições foi a soberania nacional para legislar sobre direitos trabalhistas e regular a atividade marítima e portuária.

\footnotetext{
${ }^{43}$ O PRD contava com 8 senadores na LVI Legislatura (1994-1997); 15 senadores na LVII Legislatura (1997-2000); e 17 senadores nas LVIII e LIX Legislaturas (2000-2006), número insuficiente para estruturar uma coalizão de oposição sem o apoio dos dois outros grandes partidos mexicanos, PRI e PAN.
} 


\subsubsection{Autorização para a SaÍda do Presidente do terRitório naCional, para a SAÍDA DE TROPAS DO TERRITÓRIO NACIONAL E PARA O USO DE CONDECORAÇÕES}

Ao contrário da ratificação de tratados internacionais e de nomeações diplomáticas, a autorização de viagens internacionais do Presidente e para uso e recebimento de condecorações estrangeiras, de acordo com o texto constitucional vigente durante as legislaturas estudadas, eram competências compartilhadas pela Câmara dos Deputados e pelo Senado ${ }^{44}$. Todos os pedidos eram submetidos à votação em ambas as Casas do Legislativo.

No período de $1^{\circ}$ de setembro de 1994 a 31 de agosto de 2000, foram submetidas à aprovação do Congresso um total de 44 autorizações para o Presidente se ausentar do território mexicano, das quais 43 foram aprovadas pelo Congresso e 1 ficou pendente.

$\mathrm{O}$ pedido pendente se refere à autorização para o Presidente Ernesto Zedillo ausentar-se do território mexicano no período de 8 a 10 de dezembro de 1999 para uma visita de trabalho aos Estados Unidos, o qual foi apresentado ao Senado em 23/11/1999 e aprovado. O ditame foi então encaminhado à Câmara dos Deputados em 02/12/1999, mas foi suspenso por falta de quórum para votação e depois retirado pelo Executivo.

No período de $1^{\circ}$ de setembro de 2000 a 31 de agosto de 2006, foram apresentadas ao Congresso um total de 57 autorizações para viagens internacionais do Presidente, das quais 56 foram aprovadas e 1 foi rejeitada.

A recusa foi a primeira da história do Congresso mexicano e se refere a um pedido de viagem do Presidente Vicente Fox para realizar uma visita de trabalho às cidades de Calgary e Vancouver, no Canadá, e às cidades de Seattle e São Francisco, nos Estados Unidos, entre os dias 15 a 18 de abril de 2002. O pedido foi rejeitado pelo pleno do Senado em 09/04/2002 com 41 votos a favor e 71 votos contra. As bancadas do PRI e do PRD votaram contra o pedido. Os motivos invocados para a recusa foram, de um lado, a falta de transparência do governo em relação aos reais motivos da viagem - o PRD se

\footnotetext{
${ }^{44}$ Com a reforma constitucional de agosto de 2008, a autorização de pedidos de viagem do Presidente deixou de ser atribuição do Congresso. O novo texto estabelece que apenas as ausências do Presidente superiores a sete dias necessitam de autorização prévia do Senado ou da Comissão Permanente do Congresso.
} 
manifestou exigindo a presença do Secretário de Relações Exteriores Jorge Castañeda para prestar esclarecimentos - e, de outro, a discordância em relação à condução da política externa pelo Presidente Fox, mormente no tocante ao tema da imigração e das relações diplomáticas com Cuba.

Uma segunda recusa ocorreu já no final do mandato de Fox, quando o Presidente mexicano solicitou autorização para sair do país para participar de uma reunião da Associação Econômica da Ásia do Pacífico (APEC), no Vietnã, e realizar uma visita diplomática à Austrália entre os dias 10 e 19 de novembro de 2006. Embora o pedido tenha sido aprovado no Senado, foi rejeitado na Câmara dos Deputados, sob o argumento de que a situação do país não comportaria a ausência do Presidente, tendo em vista a onda de violência no Estado de Oaxaca. Foram proferidos 187 votos a favor, de membros do PAN, 258 contra e 6 abstenções ${ }^{45}$.

As críticas de Fox à atitude da Câmara Baixa foram contundentes, pois, para o Presidente, o próprio prestígio internacional do México estava sendo colocado em risco pelos legisladores.

Tabela 23 - Autorizaç̃o para viagens internacionais

\begin{tabular}{|c|c|c|c|c|c|}
\hline Legislatura & Apresentadas & Aprovadas & Pendentes & Rejeitadas & $\begin{array}{c}\text { Porcentagem de } \\
\text { aprovação }\end{array}$ \\
\hline LVI & 14 & 14 & 0 & 0 & $100 \%$ \\
\hline LVII & 30 & 29 & 1 & 0 & $96,66 \%$ \\
\hline LVIII & 24 & 23 & 0 & 1 & $95,83 \%$ \\
\hline LXIX & 33 & 33 & 0 & 0 & $100 \%$ \\
\hline
\end{tabular}

Fontes: Tabela elaborada pela autora a partir de dados do Sistema de Informação Legislativa do Governo Mexicano e dos Diários de Debates da Câmara dos Deputados e Senado mexicanos

O exercício da competência para autorizar o recebimento e uso de condecorações estrangeiras pelo Congresso mexicano seguiu a dinâmica das votações dos outros tópicos, com grande porcentagem de aprovações.

No período de $1^{\circ}$ de setembro de 1994 a 31 de agosto de 2000, foram apresentados 1010 pedidos para recebimento e uso de condecorações estrangeiras, dos quais 998 foram

\footnotetext{
${ }^{45}$ Esta recusa ocorreu durante a LX Legislatura, iniciada em 1 de setembro de 2006 e com término em 31 de agosto de 2009. Muito embora os últimos meses do governo Fox tenham se desenvolvido sob a égide de uma nova legislatura, esta não foi incluída na análise, tendo em vista o recorte temporal adotado.
} 
aprovados, 11 ficaram pendentes nas comissões de origem e 1 foi rejeitado. O pedido rejeitado se refere ao recebimento e uso de uma condecoração conferida pelo governo do Paraguai $^{46}$ por um cidadão mexicano.

Foi também durante o governo Fox que pela primeira vez o Congresso rejeitou um pedido do chefe do Executivo para receber e usar condecorações estrangeiras. Em 22 de abril de 2004, o pedido do Presidente Fox para aceitar e usar a Medalha ao Mérito Agrícola conferida pela Organização das Nações Unidas para a Agricultura e Alimentação foi rejeitado na Câmara dos Deputados por 134 votos a favor e 264 votos contra. Os votos contrários partiram dos partidos de oposição: PRI (174 votos), PRD (17 votos contra e 3 abstenções), PVEM (15 votos), PT (4 votos) e Convergência (3 votos). O argumento apresentado pelos partidos de oposição para a recusa foi a falta de mérito do Presidente, pois o país não possuía uma política consistente na área agrícola.

No período de $1^{\circ}$ de setembro de 2000 a 31 de agosto de 2006, foram submetidos à votação 824 pedidos para recebimento e uso de condecorações estrangeiras, dos quais 807 foram aprovados, 16 ficaram pendentes nas comissões de origem e 1 foi rejeitado.

Tabela 24 - Autorização para recebimento e uso de condecoracões estrangeiras

\begin{tabular}{|c|c|c|c|c|c|}
\hline Legislatura & Apresentadas & Aprovadas & Pendentes & Rejeitadas & $\begin{array}{c}\text { Porcentagem de } \\
\text { aprovação }\end{array}$ \\
\hline LVI & 240 & 240 & 0 & 0 & $100 \%$ \\
\hline LVII & 770 & 758 & 11 & 1 & $98,44 \%$ \\
\hline LVIII & 461 & 451 & 10 & 0 & $98 \%$ \\
\hline LXIX & 363 & 356 & 6 & 1 & $98 \%$ \\
\hline
\end{tabular}

Fonte: Tabela elaborada pela autora a partir de dados do Sistema de Informação Legislativa do Governo Mexicano e dos Diários de Debates da Câmara dos Deputados e Senado mexicanos

Nas Legislaturas analisadas, não foi submetida à apreciação do Senado nenhuma autorização para saída de tropas do território. O tema, contudo, não passou ao largo da discussão. Durante o governo Fox, em setembro de 2005, foram enviadas tropas aos Estados Unidos para auxiliar as vítimas do furacão Katrina. O Senado interpretou a atitude do Presidente como violação ao artigo 76 da Constituição mexicana, que atribui à

\footnotetext{
${ }^{46}$ No Sistema de Informação Legislativa da Secretaria de Governo do México, consta apenas a informação de que a condecoração foi rejeitada na comissão de origem. Não está disponível no sistema a data da rejeição, nem seus motivos. Em pesquisa no Diário de Debates, não foi possível encontrar tal votação.
} 
Câmara Alta a competência para autorizar a saída de tropas do território nacional. O Executivo argumentou que tal autorização só seria necessária para saída de tropas em caso de guerra. A fim de apaziguar a questão, pois a tropas já haviam sido enviadas, o Senado aprovou em 06/09/2005 um decreto que ratificou a decisão de Fox ${ }^{47}$.

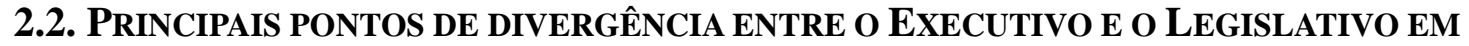 MATÉRIA DE POLÍTICA EXTERNA NO PERÍODO ANALISADO}

Durante o período analisado (1994-2006), algumas temáticas no plano internacional foram capazes de gerar embates entre os poderes, colocando à prova a capacidade dos congressistas de impor suas preferências em um reduto de tradicional domínio do Executivo. Esses atritos foram mais intensos durante o Governo Fox (20002006), que enfrentou o problema da ausência de maiorias do partido do governo, o PAN, na Câmara dos Deputados e no Senado em seu sexênio

No caso do Governo Zedillo (1994-2000), o PRI, partido do governo, detinha maioria na Câmara dos Deputados e no Senado durante os três primeiros anos. A eleição de 1997 altera este cenário e o PRI, pela primeira vez, deixa de ter maioria na Câmara dos Deputados, embora tenha preservado seu controle sobre o Senado ${ }^{48}$.

A política externa do Governo Zedillo é considerada pelos analistas como uma continuação da "nova diplomacia" implementada pelo Presidente Carlos Salinas de Gortari, que tinha como eixo central a "diplomacia comercial externa".

A diplomacia do Governo Fox, embora com alguns pontos de continuidade em relação ao seu antecessor, apresentou alterações significativas ao menos em relação a dois aspectos: direitos humanos e democracia, com implicações sobre o relacionamento com Cuba e com outros países latino-americanos, e sobre a relação com os Estados Unidos.

\footnotetext{
${ }^{47}$ A polêmica em torno do tema motivou a apresentação de diversas iniciativas, visando modificar a Constituição, para autorizar o Presidente a enviar tropas ao exterior para causas humanitárias independentemente de aprovação do Legislativo.

${ }^{48}$ Após a eleição de 1997, a distribuição de cadeiras na Câmara dos Deputados mexicana ficou da seguinte forma: 239 deputados do PRI, 122 deputados do PAN, 125 deputados do PRD, 6 deputados do PT e 8 deputados do PVEM, totalizando 500 deputados. No Senado, a maioria das cadeiras pertencia ao PRI, com 77 senadores, as demais cadeiras estavam distribuídas entre o PAN (33 senadores); PRD (15 senadores), PVEM (2 senadores), PT (1 senador).
} 
Esta mudança quanto ao conteúdo da política externa, associada ao aumento da fragmentação partidária na Câmara dos Deputados e no Senado, fizeram do Governo Fox o sexênio em que as divergências entre o Executivo e o Legislativo estiveram mais latentes.

\subsubsection{A RELAÇão COM OS ESTADOS UNIDOS}

Durante o governo Zedillo observa-se o avanço da política de maior proximidade com os Estados Unidos iniciada por seu antecessor, Carlos Salina de Gortari. O estreitamento entre os dois países foi intensificado, de um lado, pela assinatura do NAFTA, e, de outro, pelo auxílio financeiro prestado pelo governo norte-americano ao combate à crise do peso a partir de 1994.

Contudo, duas questões delicadas, o problema da certificação dada pelo governo norte-americano aos países que promovem uma efetiva luta contra o narcotráfico e a aprovação da Lei Helms Burton, em 1996, que impunha sanções aos países que realizassem investimentos em Cuba, geraram desconfortos na relação entre México e Estados Unidos.

Os congressistas não se mantiveram alheios às iniciativas norte-americanas. Foram aprovados pontos de acordo rechaçando a Lei Helms Burton e o processo de certificação unilateral realizado pelos Estados Unidos.

Em resposta à Lei Helms Burton, o Senado mexicano aprovou, por unanimidade, em outubro de 1996, a "Lei de Proteção ao Comércio e ao Investimento de Normas Estrangeiras que Contrariem o Direito Internacional”, proibindo que fossem acatadas disposições estrangeiras que afetassem o comércio e o investimento de empresas estrangeiras em outros países.

O governo Fox adotou uma estratégia mais agressiva de alinhamento com os Estados Unidos, contrariando sobretudo os partidos do Congresso mais à esquerda, que passaram a defender uma política externa mais centrada nos interesses nacionais. Essa relação de afinidade com os Estados Unidos se intensificou após os atentados de 11 de setembro de 2002, momento em que o Presidente ofereceu apoio incondicional aos norteamericanos. Essa postura de favorecimento aos interesses norte-americanos se revelou 
mais intensa nos assuntos relacionados à segurança e migração, causando desconforto nos legisladores.

O ponto alto desse debate foi a decisão sobre o voto a ser dado pelo México no Conselho de Segurança da ONU em 2003 para a invasão do Iraque. Enquanto o Congresso se pronunciava para que o México votasse contra a resolução, em conformidade com os princípios constitucionais, Fox mostrou-se vacilante quanto à postura a ser adotada pelo país, criando uma crise com o Congresso. O conflito não atingiu proporções mais amplas, pois, com a decisão unilateral dos Estados Unidos de invadirem o Iraque, a resolução sequer foi votada.

Houve também críticas do Congresso à constituição, em março de 2005, da Aliança para a Segurança e Prosperidade da América do Norte (ASPAN), composta por Canadá, Estados Unidos e México, cujo principal objetivo consiste no combate ao terrorismo, tráfico de drogas e crime organizado nas fronteiras, bem como o compartilhamento de informações de inteligência. A iniciativa foi considerada pelos legisladores da oposição como um alinhamento aos interesses norte-americanos em matéria de segurança. Outro motivo de crítica foi o fato do acordo não ter sido submetido à apreciação do Congresso.

\subsubsection{IMIGRAÇÃO}

Desde o início do sexênio de Zedillo, surgiram discrepâncias com os Estados Unidos sobre o problema da imigração ilegal de mexicanos e as medidas unilaterais adotadas pelo governo norte-americano para combatê-la.

Neste período, o governo norte-americano aprovou a ampliação de recursos para a vigilância na fronteira e chegou até a apresentar um projeto de cobrança de uma espécie de "pedágio" para a entrada no território, o qual foi rejeitado por contrariar disposições do NAFTA. Também foi autorizada a construção de um muro na zona do Estado da Califórnia contigua ao território mexicano e houve um aumento das violações aos direitos humanos dos trabalhadores mexicanos ilegais nos Estados Unidos.

$\mathrm{O}$ Congresso reagiu em diversas oportunidades em relação às políticas imigratórias norte-americanas. Em 20/05/98 e 22/10/98 foram aprovados pontos de 
acordo condenando as práticas contra imigrantes mexicanos na fronteira. Em 23/04/98, foi aprovado um ponto de acordo, convocando a Secretária de Relações Exteriores a prestar esclarecimentos sobre a ação do governo nesta área.

Em abril e maio de 2000, novos pontos de acordo foram aprovados sobre o tema. Um deles exortava o Executivo a empreender ações contra a violação de direitos humanos dos trabalhadores ilegais; o outro condenava as ações de civis armados contra mexicanos. Os pontos de discordância dos congressistas se referiam a dois aspectos principais: a ausência de ações mais efetivas do governo frente aos Estados Unidos e a falta de tratamento prioritário à temática.

Esse cenário de violação sistemática dos direitos humanos dos trabalhadores mexicanos e de uso de violência na fronteira permaneceu durante a presidência de Fox. Os congressistas incitaram o Presidente inúmeras vezes a se manifestar contra a postura norte-americana. Os legisladores do PRI chegaram a propor que o embaixador mexicano se retirasse dos Estados Unidos como forma de protesto. Havia ainda propostas de envio de cartas diplomáticas de protesto ou de apelos a organismos internacionais.

Um ponto de consenso entre os três partidos, PAN, PRI e PRD, foi a necessidade de uma postura mais assertiva frente ao aumento da violência das autoridades norteamericanas em relação aos imigrantes mexicanos, com notícias de assassinatos ao longo da fronteira e de violação aos direitos humanos.

\subsubsection{CRISES DIPLOMÁTICAS COM OS PAÍSES LATINO-AMERICANOS}

\subsubsection{A RELAÇÃo COM CUBA}

Desde 1959, o México vinha demonstrando especial simpatia pelo governo cubano, tendo inclusive se tornado o principal parceiro econômico da Ilha fora do bloco soviético. No entanto, com o início do processo de liberalização política durante o governo Zedillo, a dinâmica da relação entre os países, antes calcada pela não intervenção e até pelo apoio, em alguns casos, sofreu abalos.

As relações diplomáticas com Cuba foram relativamente estáveis ao longo dos primeiros anos do governo Zedillo. Este quadro altera-se no final de 1998, quando se 
iniciam uma série de incidentes diplomáticos entre os países, que conduziram ao estremecimento da antiga parceria entre a Ilha e o México.

Em 2 de dezembro de 1998, durante uma reunião do SELA (Sistema Econômico Latino-Americano e do Caribe), em Havana, Fidel Castro apresentou sua visão em relação ao México, enfatizando que o país estava apartado da América Latina e próximo demais aos Estados Unidos.

O embaixador mexicano em Cuba foi então instruído pela Secretária de Relações Exteriores, Rosario Green, a pedir explicações formais a Cuba pelas declarações de Fidel Castro, que desagradaram o Presidente Zedillo.

O desconforto entre os países durou até 17 de dezembro, quando Fidel Castro escreveu uma carta de desculpas ao México, restabelecendo à normalidade a relação entre os países. Inclusive, em abril de 1999, o México votou contra a resolução da Comissão de Direitos Humanos da ONU que condenava Cuba, rompendo a tradição de abster-se neste tipo de votação.

A relação entre os países voltou a estremecer em fins de 1999, quando o Presidente Zedillo declarou, na IX Cúpula Iberoamericana, em Havana, que não poderia haver nações soberanas sem pessoas livres e que a liberdade só se atinge pela democracia plena, em uma clara mensagem ao governo castrista. Para agravar o quadro, dias antes, a Secretária de Relações Exteriores havia se reunido com dissidentes do regime e com o Presidente da Comissão Cubana de Direitos Humanos e Reconciliação Nacional.

O Presidente Zedillo seguiu pressionando Fidel Castro, para que fossem garantidas as liberdades civis em Cuba, desencadeando declarações energéticas de repúdio do líder cubano. Entre novembro de 1999 e maio de 2000, não houve embaixador de Cuba no México.

As críticas de Zedillo ao governo cubano geraram descontentamento junto à oposição mexicana, sobretudo de membros do PAN e do PRD, alguns deles com vínculos de proximidade com o regime castrista. Para os congressistas da oposição, as ações de Zedillo contrariavam a postura de não-intervenção que marcara a relação do país com a Ilha durante o regime do PRI.

Contudo, é durante o governo Fox que os atritos com Cuba atingem seu ponto alto, gerando respostas mais incisivas dos congressistas, que continuavam a defender a 
não-intervenção. Em 2004, eclodiu a crise diplomática entre os países, fruto da progressiva deterioração da relação do governo do Partido da Ação Nacional com a Ilha, a qual culminou na retirada recíproca de embaixadores.

A origem da crise remonta ao ano de 2001, quando o México se absteve de votar a resolução contra Cuba na Comissão de Direitos Humanos da ONU. A despeito do voto mexicano, Fidel Castro acusou o país, em especial o Secretário das Relações Exteriores, Jorge Castañeda, de incentivar o voto contra Cuba junto a outros países.

Em 2002, em visita a Havana, Fox reuniu-se com líderes da oposição na Ilha, o que causou novos desentendimentos, potencializados pelas declarações de Castañeda, anunciando o rompimento do país com a "revolução cubana".

Neste mesmo ano, o Congresso mexicano aprovou um ponto de acordo, requisitando ao Presidente que se abstivesse de apoiar a resolução contra Cuba na Comissão de Direitos Humanos da ONU.

$\mathrm{Na}$ Conferência das Nações Unidas sobre Financiamento para o Desenvolvimento, realizada no México, Fidel Castro retirou-se, sob o argumento de que havia uma "situação especial". Os legisladores mexicanos convocaram o Secretário de Relações Exteriores, Jorge Castañeda, para prestar esclarecimentos, mas este simplesmente se calou.

Em abril de 2002, foi aprovado pelo Senado um novo ponto de acordo sobre o voto mexicano em Genebra. No documento, os legisladores exortaram o Presidente a se abster de votar. O ponto de acordo foi ignorado pelo Executivo, que votou a favor da resolução que criticava Cuba.

Em 2004, novamente os partidos de oposição exortaram o Presidente a se abster de votar contra Cuba na Comissão de Direitos Humanos da ONU. Em abril, o México votou mais uma vez a favor de uma resolução que condenava Cuba.

O Congresso aprovou um ponto de acordo, pelo qual o Secretário de Relações Exteriores era convocado a comparecer ao Senado para prestar esclarecimentos sobre a decisão de expulsar o embaixador cubano do México. Em um segundo momento, o Presidente foi exortado a retomar as relações diplomáticas com Cuba.

Após 77 dias de tensão, a crise foi minimizada. O papel do Congresso Mexicano, a pressão dos partidos políticos e a reação da sociedade civil tiveram um peso importante 
para que fossem restabelecidas as relações diplomáticas com Cuba (Flores e Dominguez, 2007).

\subsubsection{AS CRISES COM ARgENTINA E VENEZUELA}

Além dos enfrentamentos com Cuba, o governo Fox foi marcado por crises diplomáticas com outros países latino-americanos, as quais não encontram correspondência no governo de seu antecessor.

Em novembro de 2005, o governo mexicano entrou em confronto com Argentina e Venezuela, na IV Cúpula das Américas, realizada em Mar del Plata. O motivo do enfrentamento deveu-se ao apoio mexicano à proposta dos Estados Unidos de impulsionar à ALCA (Àrea de Livre Comércio das Américas), contra a qual se opunham os países do Mercosul. Fox chegou a propor que os países favoráveis à ALCA fïrmassem um comunicado de apoio ao livre comércio, o que foi interpretado pelos países da América do Sul, em especial Argentina, Brasil e Venezuela, como uma mensagem clara de alinhamento aos interesses norte-americanos.

No caso da Argentina, os desentendimentos tiveram início com o cancelamento por Néstor Kirchner de uma reunião bilateral entre os países marcada com antecedência, o que desagradou Fox. À IV Cúpula das Américas, seguiram declarações de ambos os países questionando a postura adotada durante o encontro. Para Fox, Kirchner estava preocupado em defender os interesses dos grupos internos da Argentina, em detrimento da comunidade internacional. Para Kirchner, a diplomacia de Fox era marcada pela sujeição aos mais fortes.

As atitudes de Fox na IV Cúpula das América foram lamentadas pelo Senado mexicano. A crise foi solucionada pela redação de um comunicado conjunto dos Secretários de Relações Exteriores de ambos os países, afirmando a importância da relação bilateral entre México e Argentina.

Quando as relações com a Argentina se normalizaram, eclodiu um novo conflito diplomático, desta vez com a Venezuela, motivado por declarações de Hugo Chávez, criticando a postura de Fox de sujeição aos interesses norte-americanos. Foram 
solicitados pedidos de explicação à embaixada venezuelana, cujas atitudes não satisfizeram Fox, que exigia um pedido formal de desculpas.

A intensificação da crise diplomática com a Venezuela levou a bancada priísta a se articular no Senado para apresentar um ponto de acordo, em que a Câmara Alta exigia uma reunião formal com o Presidente Fox e o Secretário de Relações Exteriores Derbez ${ }^{49}$ "para discutir os termos da política exterior que seria adotada no resto da administração".

A proposta tinha um outro condicionante, que, logo após a reunião, "qualquer solicitação de autorização para se ausentar do território nacional que o Executivo Federal submeta ao Senado da República deve vir acompanhada de sua agenda e discurso, os quais deverão ser previamente acordados entre as partes" $"$. A proposta foi, contudo, barrada por uma articulação do partido governista.

Em 13 de novembro, Chávez fez novas declarações contra o governo de Fox, às quais a diplomacia mexicana reagiu com uma ameaça de rompimento da relação entre os países. Um dia depois, o embaixador Venezuelano retirou-se do México e o governo mexicano condicionou a acreditação de um novo embaixador a um pedido formal de desculpas.

Declarações em tom provocativo continuaram a alimentar os desentendimentos entre os países, culminando, em maio de 2006, com um anúncio formal de Chávez sobre a retirada da Venezuela do G-3, acordo comercial com o México e Colômbia.

A crise produziu ressonâncias na campanha presidencial de 2006, em que o candidato do PRD, Andrés Manuel López Obrador, foi acusado de receber apoio econômico da Venezuela; e na aspiração da Venezuela de ocupar um assento no Conselho de Segurança da ONU, que disputava com a Guatemala, tendo o embaixador mexicano se manifestado, para que o país desistisse de lutar pela vaga. Até o fim do governo Fox, a relação entre os países não havia voltado à normalidade.

O conflito com a Venezuela dividiu os atores políticos e sociais no México. De um lado, alguns congressistas do PRD apoiaram Chávez e chegaram até a acompanhar o embaixador venezuelano até o aeroporto. De outro, o governador do Distrito Federal, do

\footnotetext{
${ }^{49}$ Luis Ernesto Derbez, membro do PAN, foi Secretário de Relações Exteriores nos três últimos anos do governo Fox (2003-2006), tendo sucedido Jorge Castañeda Gutman, que exerceu o cargo entre 2000 e 2003.

${ }^{50}$ BECERRIl, Andrea e BALLINAS, Victor. "Plantean senadores del PRI condiciones escrictas para aprobar viajes de Fox", em La Jornada, 11/11/2005.
} 
mesmo PRD, apoiou Fox, que também contou com respaldo do PAN (Flores \& Domínguez, 2007: 34).

\subsection{O SALDO DA DISPUTA ENTRE OS PODERES}

Os episódios de enfrentamento entre o Congresso e o Executivo em temas de política externa durante o governo Zedillo foram bastante pontuais e de pequena repercussão. $\mathrm{Na}$ maior parte dos casos, restringiram-se a exortações, para que o Presidente adotasse medidas mais energéticas na defesa dos interesses do país e de seus nacionais, sobretudo em temas da agenda bilateral com os Estados Unidos, como a imigração.

Embora Zedillo tenha introduzido algumas mudanças nas diretrizes de ação externa do país, visando adequá-las ao novo contexto político interno de início de democratização e ao novo contexto econômico de vigência do NAFTA e de crise do peso, o Presidente apresentava a seu favor o controle de maiorias na Câmara dos Deputados, ao longo dos três primeiros anos de governo, e no Senado, durante todo o seu sexênio.

O domínio do PRI no Senado, que concentra a maior parte das atribuições em política externa, garantiu certa tranquilidade a Zedillo. Apenas o PRD apresentou-se como verdadeira oposição, mas o reduzido número de cadeiras ocupadas pelo partido impediu que suas ações ganhassem maior repercussão.

A mudança na composição da Câmara dos Deputados nas eleições de 1997, com a perda de hegemonia pelo PRI, chegou a preocupar o Presidente Zedillo, que retirou um pedido de viagem internacional em 1999, já aprovado pelo Senado, temendo uma retaliação na Câmara Baixa pelos partidos de oposição, que pela primeira vez poderiam fazer frente ao partido do governo.

A assinatura dos Acordos de Proteção Recíproca de Investimentos Estrangeiros (APRI’s) foi o tema mais delicado durante este período, gerando verdadeira polarização entre Executivo e Congresso. Os congressistas do PRD, contando em alguns casos com o apoio de membros PAN, passaram a questionar os reais benefícios gerados no país por tais acordos, que se inseriam na estratégia do Executivo de abertura comercial e diversificação de parceiros econômicos. 
A relação entre Executivo e Congresso durante o Governo Zedillo no âmbito da política externa apresentou como principais características: a) predomínio de uma postura passiva do Congresso, com a existência de conflitos pontuais e de pequena repercussão; b) dificuldades do PRD de conformar uma oposição efetiva ao governo, face ao alinhamento entre PAN e PRI na maior parte das temáticas internacionais; c) fraco sistema de separação de poderes, com predomínio do presidencialismo forte, a despeito da nova composição da Câmara dos Deputados a partir de 1997, que pouco repercutiu na área internacional; d) ligeiro incremento das propostas legislativas visando alterar o sistema de distribuição de competências em política externa; e) inexistência de um contrapeso às ações do Executivo; f) apatia do Senado controlado pelo PRI.

Portanto, no sexênio de Zedillo, o Congresso ainda não se apresentava como um ator disposto a disputar espaço na construção da política externa do país. Os episódios pontuais citados são manifestações dos primeiros reflexos de uma composição mais heterogênea das Casas Legislativas, sem representar um contrapeso real ao Executivo, que permaneceu soberano na condução externa do país, apoiado pelas maiorias do PRI.

Esta situação se altera no sexênio seguinte. Os incidentes diplomáticos com os países latino-americanos e a reorientação da relação bilateral com os Estados Unidos durante o governo Fox geraram um cenário de conflito e de mútua crítica entre os poderes. Os legisladores consideraram que era chegada a hora de enviar mensagens mais contundentes ao chefe do Executivo a respeito da condução da política exterior. Em alguns casos, o Congresso tentou, sem êxito, resolver sozinho a situação.

A estratégia de embate de Fox em relação ao Legislativo ia de encontro a uma das bandeiras do PAN na plataforma eleitoral para as eleições de 2000, que era justamente promover reformas institucionais que permitissem ao Congresso ter um papel mais ativo em política externa.

Para Flores e Dominguez (2007), as causas para tais crises se encontram na mudança de orientação da política exterior mexicana, que implicou em uma maior proximidade com os Estados Unidos, e no processo de tomada de decisões do governo, que concentrou o manejo da crise nas mãos de uns poucos funcionários e formulou declarações imprudentes. 
Esta postura contrariava frontalmente a política exterior mexicana desenvolvida nos anos 70, 80 e início dos anos 90, em que o país atuou como um líder da América Latina e principal mediador da relação dos países da região com os Estados Unidos.

O que estava em jogo com a nova forma de atuação do governo Fox no plano internacional eram os cânones básicos da política externa mexicana e a relação com um ator fundamental, os Estados Unidos. A substituição do tradicional multilateralismo como vetor da política externa mexicana por um "bilateralismo multilateral", fruto do realinhamento estratégico com os interesses norte-americanos, associada ao abandono de referenciais básicos como o princípio da não-intervenção e a manutenção de relações cordiais com Cuba, geraram desconfortos no interior do Legislativo.

Para os partidos opositores, PRI e PRD, os princípios de condução das relações internacionais estão enunciados na Constituição e não poderiam ser simplesmente rechaçados por Fox. Para o Governo, por outro lado, a política externa deveria se orientar pelos interesses nacionais e não por princípios rígidos com pouca aplicação prática.

Sob a ótica do Legislativo, a crítica aos princípios que tradicionalmente regeram a atuação do México nas relações internacionais era o mecanismo utilizado pelo Executivo para atacar o Congresso e diminuir sua capacidade de controle sobre a política exterior. Uma situação ilustrativa deste argumento seria o tratamento desigual dado a países com histórico de violação aos direitos humanos: enquanto Rússia e China não recebiam qualquer tipo de reprovação, a censura se concentrava em Cuba, em consonância com os interesses norte-americanos (Casillas, 2003).

Além da proximidade maior com os Estados Unidos, também a definição de prioridades na agenda bilateral entre os países, que colocou a imigração como tema central, em detrimento de outros temas de relevância como o comércio, os direitos humanos dos imigrantes e outras questões relacionadas à fronteira, desagradou os congressistas.

Para o Executivo, tratava-se da busca de um realinhamento estratégico com os Estados Unidos, visando colocar o México no centro dos países latino-americanos, afastando a democracia e os direitos humanos como únicos parâmetros de mediação na relação com outros países e um possível juízo de reprovação em relação ao passado. 
A aspiração do governo Fox de concorrer a uma das vagas no Conselho de Segurança da ONU intensificou o clima de animosidade entre os poderes. Os congressistas da oposição acreditavam que a obtenção de um assento no Conselho de Segurança colocaria o país em uma situação de enfrentamento inevitável com os Estados Unidos. O Executivo, contudo, interpretava como uma oportunidade de viabilizar um acordo imigratório, em troca de apoio no interior do órgão.

Durante a administração Fox, foi também intenso o conflito entre o Congresso e a Secretaria de Relações Exteriores, em especial com o Primeiro Secretário de Relações Exteriores, Jorge Castañeda. Vários fatores contribuíram para o aumento das tensões, como a mudança na política do México em relação a Cuba, a saída de tropas mexicanas para práticas militares sem autorização do Senado e a inexpressiva reação da diplomacia nacional à decisão da Suprema Corte norte-americana que privou um imigrante mexicano de exercer seus direitos trabalhistas.

O veto do Senado à viagem presidencial ao Canadá e Estados Unidos, em abril de 2002, foi interpretada por muitos como uma reprovação à maneira como Castañeda estava conduzindo a política externa do país. Analisando a ação do Senado, Casillas pondera que:

“En nuestro país, en cambio (comparação com o Senado norteamericano), desde siempre, el Senado de la República estuvo ausente de la vida parlamentaria y lejos de influir las decisiones, funcionaba como mero sancionador de disposiciones previamente acordadas. Cementerio político, lugar para el asilo o el exilio, la Cámara Alta tuvo siempre un papel secundario, solo útil para la formalidad de un sistema donde los equlilibrios fueron siempre escasos. A pesar de que la Constituición le otorgó la representación de los estados y facultades para contrarrestar los excesos de poder - es el jurado de sentencia em los procesos de juicio político - por su composición y aún por su dinámica, la democratización no habia pasado por el Senado de la Republica hasta el año 2000 y es compresible que su reactivación significara 
el ejercicio de algunas de sus facultades, que aun añejas y obsoletas, significaban la integración efectiva de uno actores centrales em la politica exterior de nuestro país" (Casilla, 2003: $58)$.

No momento auge da crise, foi publicado um informe da União Européia, cuja conclusão era de que, no México, os partidos políticos e o Poder Legislativo obstaculizavam os trabalhos do Presidente Vicente Fox.

Os enfrentamentos entre o Congresso e o Presidente Fox no tocante às diretrizes da condução da política externa representam um fato inédito na história política do México, que marca a entrada do Legislativo na arena política internacional. A conjugação de uma mudança substancial no conteúdo da política externa com uma composição heterogênea das Casas Legislativas, sem maiorias para o Governo, contribui para que esse processo tenha se desencadeado justamente no governo Fox.

Contudo, o saldo da luta política que marcou o período em termos de ações concretas do Legislativo para tentar confrontar o Executivo e o resultado efetivo de tais ações ficou abaixo do esperado. Duas negativas de autorização de viagem internacional, uma recusa de uso de condecoração e uma proposta visando disciplinar as visitas do Presidente a outros países, não aprovada, foi o que de concreto produziram os congressistas.

O restante da crise se resumiu a declarações de discordância e exortações contra o Executivo, as quais não impediram que Fox passasse por cima das preferências dos congressistas e desenvolvesse uma política externa centrada na elite governamental e no seu projeto político. Talvez o caso mais exitoso de ação dos congressistas tenha sido a retomada das relações diplomáticas com Cuba, embora estes não tenham conseguido evitar os votos favoráveis do México a resoluções condenando a Ilha na Comissão de Direitos Humanos da ONU.

Em linhas gerais, o processo de tomada de decisão na política exterior mexicana se centrou basicamente na elite governamental, com o Presidente e os Secretários de Relações Exteriores e de Governo assumindo o papel determinante. Outros atores 
políticos e sociais não foram levados em conta em seu desenho e implementação (Flores \& Dominguez, idem: 37).

É preciso compreender que o pano de fundo da disputa entre os poderes não é a construção de uma política externa de Estado, a partir de uma ação concertada entre Executivo e o Legislativo, mas sim o seu uso doméstico. A visibilidade de certos temas da agenda diplomática mexicana facilitou o processo de "politização" da política externa, inserindo-a no jogo de forças dos partidos políticos, embora nem sempre esta postura revelasse uma especial preocupação com a atuação externa do país (Velázquez, 2007).

De um lado, os legisladores da oposição utilizaram as críticas dirigidas ao Presidente Fox como instrumento para ganhar apoio interno. De outro, Fox utilizava o confronto aos cânones da política externa mexicana como estratégia para minar a influência do Congresso, ao mesmo tempo em que o PAN buscava dar cobertura às ações do governo e preservar a força do partido. "A política externa mexicana durante a administração Fox foi um assunto doméstico de grande importância para o sistema político mexicano" (Velázquez, idem: 2).

Reforça este argumento o fato das crises com os países latino-americanos terem sido utilizadas na campanha das eleições presidenciais de 2006, alimentando o processo de politização da política externa em curso no país. O PAN de Vicente Fox e Calderon utilizou a crise da Venezuela para criticar o PRD, que saiu em defesa de Chávez. Em oposição, o PRD criticou os desmandos da política externa do PAN sob o comando de Fox.

Para Velázquez (2008), as principais características da relação entre o Executivo e o Legislativo em política externa durante o Governo Fox foram: a) um constante atrito entre os poderes em relação a temas específicos, como Cuba, imigração e a cooperação com os Estados Unidos na área de segurança; b) a tentativa de estender as atribuições em matéria de política externa por meio de alterações legislativas e pontos de acordo; c) uma separação de poderes que se reflete na tentativa do Congresso de influenciar o processo de tomada de decisão e assumir posições independentes em relação ao Executivo em temas de política externa; d) o funcionamento de um tíbio sistema de freios e contrapesos entre os poderes. 
As razões que explicariam o conflito entre os poderes seriam: as diferenças ideológicas entre os partidos no Congresso, particularmente o PRD, sobre a maneira pela qual deve ser conduzida a política externa; a falta de consenso entre os principais atores políticos; a luta pelo poder entre Executivo e Legislativo com o fim do regime do PRI; e a maior autonomia obtida pelo Congresso a partir de 2000.

Contudo, o autor mexicano destaca a necessidade de se avaliarem duas perspectivas distintas da relação entre o Congresso e o Executivo durante o sexênio de Fox. Do ponto de vista quantitativo, esta teria se caracterizado pela cooperação, com a aprovação pelo Legislativo da maior parte das iniciativas propostas pelo Presidente.

Qualitativamente, a relação pode ser considerada conflituosa em razão dos seguintes fatores: a) as diferenças ideológicas sobre alguns temas de política entre o Presidente Vicente Fox e alguns legisladores, sobretudo do PRD; b) os novos elementos do sistema político mexicano após o ano de 2000, com a emergência de novos atores; c) as confrontações entre o Primeiro Secretário de Relações Exteriores, Jorge Castañeda, e alguns legisladores da oposição, especialmente nos assuntos relacionados a Cuba e Estados Unidos; d) a falta de vontade do presidente Fox de construir um consenso entre os partidos políticos no Congresso sobre temas centrais, como Cuba, Estados Unidos e Venezuela; e) a separação de poderes trouxe maior margem de autonomia ao Congresso, ampliando os enfrentamentos com o Executivo; f) em alguns casos de política externa, o Congresso buscou atuar de maneira independente de Executivo e fazer valer suas preferências.

A despeito do reconhecimento da natureza conflituosa da relação entre o governo Fox e o Congresso, com maior projeção do Legislativo em temáticas internacionais, Velázquez considera que o êxito dos congressistas em representar um contrapeso efetivo às ações da Presidência foi baixo, prevalecendo o tradicional domínio do Executivo em política externa:

"El sistema de pesos y contrapesos no fue muy efectivo. Aunque uma de sus propuestas de campana fue fortalecer el papel del Senado em política exterior, Vicente Fox simplesmente desdeñó al Congreso en varios asuntos, tales como el voto em Ginebra sobre 
Cuba, la petición de enviar notas de protesta ante Estados Unidos por su política migratória, etcétera. En este sentido, el proceso de toma de decisiones de la política exterior mexicana siguió centrandóse em el Poder Ejetivo. Es decir, se confirma la existência de uma supremacia del Ejecutivo sobre el Legislativo em decisiones de política exterior. Rara vez, el presidente Vicente Fox busco cabildear com los representantes populares para buscar su apoyo o evitar la confrontación. Tampoco busco consensos para proyectar una posición respaldada por el Congreso mexicano" (Velázquez, 2007: 38).

A conclusão de Guadalupe Gonzaléz caminha no mesmo sentido, embora a autora destaque a debilidade institucional do Congresso como um dos fatores que impediram uma atuação mais efetiva no plano internacional:

"La conclusión general que deriva del análisis es que, a pesar de la mayor visibilidad de las cuestiones internacionales em la agenda legislativa y la cresciente actividad de los partidos políticos en asuntos relacionados con el exterior, a lo largo del período de gobiernos divididos no han avanzado los diversos intentos de reestructuración burocrática para mejorar la coordinación entre las instancias de gobierno com atribuiciones em la formulación e instrumentación de la política exterior ni tampoco las iniciativas de reforma para transformar el balance de poder y autoridad entre el Ejecutivo y el Legislativo em este ámbitio. Entre 1997 y 2007, el predomínio presidencial y la conducción segmentada de la política exterior se mantuvieron sin mayores cambios, y el Congreso no logró ejercer a cabalidad sus atribuiciones constitucionales $\mathrm{ni}$ fortalecer su capacidad institucional como un contrapeso real e instancia de supervisión de las acciones del Ejecutivo. Se transformó, principalmente, em uma 
caja de resonancia a la que los principales actores políticos - el gobierno em funciones y los partidos de oposición - recurren para publicitar sus posiciones sobre temas de política exterior, particularmente aquellos com mayor impacto electoral por su visibilidad o importancia simbólica" (González, 2007:4).

O saldo do confronto entre os poderes ao longo do período analisado foi um progressivo processo de politização da política externa mexicana, a partir da entrada do Congresso na arena de disputa política. Observa-se um aumento do nível de atividade dos congressistas no tocante à apresentação de propostas legislativas e pontos de acordos sobre temas de política externa. O nível de divergência também se intensificou, com a incorporação pelos partidos políticos em suas plataformas eleitorais e de governo de temas da área internacional, e com a polarização entre Congresso e Executivo em algumas questões sensíveis, como a relação com Cuba e Estados Unidos.

Entretanto, o Congresso apresentou uma capacidade bastante limitada de se estruturar como um contrapeso efetivo ao Executivo na área internacional. Nos momentos mais críticos de enfrentamento entre os poderes, as ações do Congresso não foram capazes de compelir o Presidente a incorporar suas preferências ou a flexibilizar posições. Alto nível de atividade, com baixa assertividade, são os traços característicos da atuação do Congresso mexicano no sexênio de Fox.

O processo de democratização no México se, de um lado, abriu espaço para que o Congresso se apresentasse como um ator disposto a buscar espaço na arena de disputa da política internacional, manifestando suas discordâncias em relação ao Executivo e tentando, em alguns casos, empreender ações autônomas nesta seara; de outro, ao menos nesta primeira etapa de acomodação das estruturas de poder, não produziu o efeito esperado de "poliarquização" do processo decisório sentido no âmbito da política doméstica, já que o planejamento e implementação das ações do México no plano internacional continuaram concentrados nas elites governamentais ligadas ao Executivo. 


\section{SEÇão III - ANÁLISE de CASOS}

A presente seção tem por objetivo ilustrar, a partir de uma abordagem casuística, alguns fatores da dinâmica de atuação do Congresso mexicano em política externa com impactos sobre a análise desenvolvida neste trabalho, notadamente: a) a falta de consenso no interior das Casas Legislativas sobre o sistema de divisão de atribuições em matéria de política externa; b) o papel desempenhado pela Câmara dos Deputados, a despeito da concentração de atribuições no Senado; c) o acordo executivo, mecanismo que pode ser utilizado pelo Presidente para excluir o Congresso do jogo político internacional.

Neste sentido, a divisão de preferências entre as Casas do Congresso quanto às reformas nas prerrogativas em matéria de relações internacionais será representada pela votação da Lei sobre a Aprovação de Tratados em Matéria Econômica.

O papel desempenhado pela Câmara dos Deputados será apreciado a partir do caso da taxação do xarope de milho, o qual, não apenas ilustra os recursos de que dispõe a Câmara Baixa para atuar em temas da área internacional, como também sugere, na esteira da observação de Mena (2006), que haveria diferença de perfil entre o Senado, mais favorável ao livre comércio, por apresentar uma base eleitoral mais abrangente, e a Câmara dos Deputados, mais paroquialista, por contar com uma base eleitoral mais localizada.

A confirmação do diagnóstico de Mena pressupõe um acompanhamento do comportamento das duas Casas Legislativas nas próximas décadas, com a acomodação do processo democrático, constituindo importante agenda de pesquisa a ser enfrentada pelos estudiosos do tema.

Por fim, a análise do uso do acordo executivo como estratégia para afastar a necessidade de se submeter à apreciação do Congresso temas controvertidos e com forte oposição interna terá como referência a constituição da Aliança para Segurança e Prosperidade da América do Norte (ASPAN). 


\section{DiVisão de PREFERÊNCIAS ENTRE AS CaSAS do CONGRESSO: A VOTAÇão da LEI SOBRE A APRovaÇão de Tratados EM Matéria EconôMica}

O projeto da Lei sobre a Aprovação de Tratados em Matéria Econômica foi apresentado pela senadora Maria del Carmen Ramirez Garcia, do PRD, em 26 de abril de 2001, tendo por objetivo ampliar as atribuições do Senado no tocante ao acompanhamento das negociações de tratados internacionais. Após tramitar pelas comissões, o texto foi aprovado em 13 de dezembro de 2002 na Câmara Alta, com dispensa de segunda leitura e sem discussões, por 97 votos a favor e nenhum contrário.

A aprovação tranquila no Senado não se reproduziu na Câmara dos Deputados, em que a matéria gerou grande divisão interna. Submetido à votação em 29 de abril de 2004, o projeto recebeu 270 votos a favor, de membros do PRI, PRD, PVEM e PT; e 129 contra, de membros do PAN, que contou com três abstenções. Do PRI foram 161 votos a favor, com uma abstenção; do PRD 91 votos; do PVEM 10 votos, e do PT e Convergência 4 votos cada.

A diferença de resultados na votação da Câmara dos Deputados e do Senado ilustra a falta de consenso no interior do Legislativo mexicano sobre os termos em que deve se dar a ampliação de suas atribuições em matéria de política externa.

De um lado, o Senado se mostrava interessado em ampliar as atribuições que constitucionalmente já são concentradas na Câmara Alta, afirmando-se como o órgão por excelência responsável pelo acompanhamento e fiscalização das ações do Executivo na área internacional. A percepção era de que os instrumentos de controle ex post eram insuficientes, o que impunha a necessidade de desenvolver e regulamentar mecanismos de controle ainda nas fases de negociação dos instrumentos internacionais.

De outro, a Câmara dos Deputados estava dividida não apenas quanto à conveniência de ampliar os poderes do Senado, como também o PAN, partido do governo, estava preocupado com a possibilidade do Senado oferecer embaraços à atuação do Executivo.

Durante o período analisado, os deputados mexicanos apresentaram inúmeras propostas de reforma constitucional, visando estender as atribuições do Senado em matéria de política externa à Câmara dos Deputados. Com a visibilidade obtida por 
alguns temas internacionais junto à opinião pública, os deputados acreditavam que a Câmara Baixa não podia ser excluída do processo de tomada de decisão em política externa.

\section{Tabela 25 - Votação na Câmara dos Deputados da Lei sobre}

\section{Aprovação de Tratados em Matéria Econômica}

\begin{tabular}{|c|c|c|c|c|c|c|c|}
\hline Votos & Total & PRI & PAN & PRD & PVEM & PT & CONV \\
\hline A Favor & 270 & 161 & 0 & 91 & 10 & 4 & 4 \\
\hline Contra & 129 & 0 & 129 & 0 & 0 & 0 & 0 \\
\hline Abstenção & 4 & 1 & 3 & 0 & 0 & 0 & 0 \\
\hline Ausente & 97 & 62 & 19 & 6 & 7 & 2 & 1 \\
\hline Total & 500 & 224 & 151 & 97 & 17 & 6 & 5 \\
\hline
\end{tabular}

Fonte: Gaceta Parlamentaria, 29 de abril de 2004, Cámara de Diputados Mexicana

\section{O PAPEL DA CÂMARA dOS DEPUTADOS: O CASO DA TAXAÇão DO XAROPE DE MILHO}

Muito embora a Câmara dos Deputados não detenha atribuições constitucionais no campo da política externa, seu ativismo nessa área pode ser exercido por meio de mecanismos não tradicionais, relacionados ao exercício de suas prerrogativas em âmbito doméstico, tais como o controle orçamentário e a jurisdição sobre os impostos domésticos.

No México, a Câmara dos Deputados e o Senado dividem a competência para aprovar a legislação fiscal: cabe às duas Casas Legislativas aprovar a Ley de Ingresos, a lei que contém as fontes de receita do governo (Lei da Receita Pública Anual); enquanto a Câmara dos Deputados, nos termos do artigo 74 da Constituição, concentra a atribuição para aprovar o Presupuesto de Egresos, o orçamento das despesas do governo ${ }^{51}$.

${ }^{51}$ Artículo 74. Son facultades exclusivas de la Cámara de Diputados:

$$
\text { (...) }
$$

IV. Aprobar anualmente el Presupuesto de Egresos de la Federación, previo examen, discusión y, em su caso, modificación del Proyecto enviado por el Ejecutivo Federal, una vez aprobadas las contribuciones que, a su juicio, deben decretarse para cubrirlo, así como revisar la Cuenta Pública del año anterior. 
Portanto, a Câmara dos Deputados tem o poder de aprovar o dispêndio e a faculdade de autorizar e aprovar os gastos do governo, podendo afetar a política comercial por meio de sua jurisdição sobre a política fiscal e da criação de impostos domésticos sobre produtos estrangeiros (Mena, 2004a: 72-73).

Importante destacar a diferença de posicionamento das Casas do Legislativo quanto à temática de acordos comerciais. Se, de um lado, o Senado demonstra grande apoio à liberalização comercial do país, de outro, a Câmara dos Deputados se mostra muito mais responsiva às demandas locais, mesmo que seu atendimento implique em desrespeito aos acordos assumidos internacionalmente pelo México (Mena, 2006).

Neste diapasão, a Câmara dos Deputados aprovou em 31 de dezembro de 2001 um dispositivo na Ley de Ingresos da Federação, com vigência a partir de janeiro de 2002, que impunha um imposto de $20 \%$ a todas as bebidas que tinham em sua composição xarope de alta frutose de milho em lugar de açúcar de cana, visando proteger o mercado nacional de açúcar da invasão do xarope de frutose de milho dos Estados Unidos (Hufbauer \& Schott, 2005).

O propósito do imposto era estimular o uso em bebidas do açúcar produzido no país, em detrimento do xarope de milho, importado dos Estados Unidos. Tratava-se de uma medida de retaliação aos Estados Unidos, que não cumpriram os compromissos assumidos no NAFTA de garantir acesso ao seu mercado para exportações de açúcar mexicano. O Executivo mostrou-se contrário à taxação.

Mesmo dispondo de poder de veto após a aprovação do texto de lei pelo Congresso, no caso específico do imposto sobre xarope de milho, inserido na lei geral sobre receitas anuais, não pode o Executivo barrá-lo, pois não existe veto seletivo no sistema político mexicano.

Como medida alternativa, em 5 de março de 2002, o presidente Fox publicou no Diário Oficial da Federação um decreto suspendendo a cobrança da taxa de $20 \%$ sobre todos os refrescos e bebidas hidratantes que utilizavam edulcorantes distintos do açúcar da cana por sete meses. Os deputados defendiam que a suspensão se limitasse a quatro meses.

Em 2 de abril de 2002, o Plenário da Câmara dos Deputados aprovou um Ponto de Acordo, que ordenava à Presidência da Mesa Diretora a promoção de uma demanda 
constitucional contra o ato realizado pelo Executivo Federal. $\mathrm{O}$ argumento dos deputados era de que o Presidente não poderia legislar sobre impostos a partir de decretos, sendo esta competência do Congresso. A Suprema Corte de Justiça invalidou o decreto do Presidente Fox por vício de inconstitucionalidade.

Em 11 de dezembro de 2002, a Câmara dos Deputados restabeleceu a cobrança de $20 \%$ de imposto sobre o xarope de milho com alto teor de frutose e sobre seus concentrados para o ano fiscal de 2003. Para os deputados, era preciso manter a proteção à indústria açucareira mexicana contra os concorrentes norte-americanos. Em 2004, houve nova tentativa do Executivo de eliminar o imposto, a qual foi barrada desta vez pelo Senado.

O embate levou os Estados Unidos a recorrerem à Organização Mundial do Comércio (OMC) para resolver a questão. Em 2006, foi prolatada sentença no órgão de Solução de Controvérsias da OMC, determinando a extinção do imposto.

$\mathrm{Na}$ esteira do argumento de Mena (2006), este caso demonstra de que forma a competência sobre legislação doméstica pode impactar no plano internacional, abrindo caminho para uma maior atuação da Câmara dos Deputados em uma seara em que as atribuições constitucionais estão concentradas no Senado.

O uso de legislação doméstica como estratégia de política comercial para a defesa de interesses locais pela Câmara dos Deputados apresenta uma margem de atuação mais ampla se comparada à dinâmica de ratificação dos tratados internacionais pelo Senado, em que, via de regra, prevalecem as preferências do Executivo. A existência de partidos coesos com preferências semelhantes favoráveis aos acordos comerciais na Câmara Alta, associada às dificuldades de alteração no status quo, fazem com que o Executivo encontre poucos constrangimentos à aprovação de instrumentos internacionais.

No âmbito da legislação doméstica, a situação é distinta. A ausência de veto parcial e de mecanismos de controle de agenda pelo Executivo, como a fixação de prazos para a apreciação de projetos pelo Congresso e o poder de expedir decretos com força de lei, converteram o Legislativo, com o fim do regime autoritário, no principal propositor de leis aprovadas, cabendo ao Presidente um papel mais reativo (Nacif, 2003).

Contudo, estatisticamente, ainda é pequeno o uso pelo Congresso de legislação doméstica como instrumento de política externa, em geral, e de política comercial, em 
particular, conforme se verifica no levantamento sobre legislação substantiva constante na seção anterior. $\mathrm{O}$ caso da taxação do xarope de milho representa um importante divisor de águas neste aspecto, dado os impactos gerados tanto na relação com o Executivo, quanto com os Estados Unidos.

\section{ACORDOS EXECUTIVOS E A NEGOCIAÇÃO DA ASPAN}

Em 23 de março de 2005, foi anunciada pelos Presidentes dos Estados Unidos, México e Canadá a constituição da Aliança para Segurança e Prosperidade da América do Norte (ASPAN), consistente em um esforço trilateral para aumentar a segurança e prosperidade da América do Norte, por meio de maior cooperação e compartilhamento de informações que permitam tornar a região mais segura contra ameaças, como o terrorismo, e mais competitiva frente a outros blocos econômicos, como o europeu e o chinês.

A Aliança, posteriormente conhecida como NAFTA-Plus, tinha como sustentação agendas específicas para a área de segurança e de prosperidade, com vistas a estreitar os vínculos entre os países da América do Norte em setores estratégicos. Para a Agenda da Segurança, foram propostas as seguintes diretrizes:

1) Instrumentalizar estratégias comuns de segurança fronteiriça e bioproteção;

2) Melhorar a proteção de infra-estrutura importante e implementar um modelo comum de resposta a emergências;

3) Instrumentalizar melhorias na segurança aérea e marítima, fazer frente a ameaças extra-regionais e melhorar as alianças em matéria de informação de inteligência;

4) Implementar uma estratégia para agilizar a fronteira, a fim de aumentar a capacidade instalada e melhorar o movimento legítimo de pessoas e mercadorias na fronteira.

Já a Agenda da Prosperidade tem como pilares de atuação: 
1) Aumentar a produtividade mediante a cooperação em matéria de regulação, a fim de gerar crescimento, mantendo, ao mesmo tempo, elevados padrões de saúde e segurança;

2) Promover a cooperação setorial para facilitar a atividade empresarial em setores como energia, transportes, serviços financeiros e tecnologia;

3) Reduzir os custos das exportações e importações mediante movimento eficiente de bens e pessoas;

4) Fortalecer o compromisso com o cuidado ao meio-ambiente e criar um controle mais confiável e seguro de alimentos, que facilitará o comércio de produtos agrícolas e protegerá a população de enfermidades.

A maneira pela qual foi articulada a constituição da ASPAN pelos Chefes de Estado de Estados Unidos, Canadá e México gerou forte descontentamento no interior dos países membros, já que a sociedade civil e os Legislativos nacionais foram alijados do processo de tomada de decisão. A adoção do obscuro formato de um Acordo Executivo, o qual, a princípio, não necessitaria ser ratificado pelos Congressos nacionais, foi vista como uma manobra para excluir do debate público temas sensíveis tratados pela Aliança.

No caso do México, apenas em 16 de março de 2005, sete dias antes do anúncio oficial de criação da ASPAN, o Senado da República foi informado sobre o avanço nas negociações de um Tratado de Livre Comércio da América do Norte, visando agilizar a integração do México com a região.

Em 30 de março de 2005, o informe foi encaminhado às Comissões Unidas de Relações Exteriores e América do Norte, para estudo e elaboração de uma proposta de ponto de acordo relativa ao estabelecimento da ASPAN.

Em 28 de abril de 2005, o Senado aprovou em votação econômica um ditame, solicitando ao Executivo a constituição de um grupo de trabalho entre a Secretaria de Relações Exteriores e o Senado para avaliar os avances e resultados da ASPAN.

Em 22 de novembro, foi aprovado um novo ditame, solicitando ao Executivo Federal informações sobre os acordos subscritos no marco da ASPAN. Em 15 de 
dezembro, o Senado aprovou um quarto ponto de acordo, solicitando que se analisassem as implicações da ASPAN para o incremento da segurança e competitividade na região.

A insistência dos congressistas mexicanos ao longo dos meses que se seguiram à criação da ASPAN em obter maiores informações sobre a Aliança resultou de um profundo descontentamento pela adoção de um acordo executivo, sem passar pela aprovação do Senado. Isso porque o acordo tocava em temas sensíveis como a segurança fronteiriça e a questão energética, visando uma maior abertura dos setores elétricos e de hidrocarbonetos, os quais gozam de proteção constitucional e foram objeto de tentativas frustradas de reforma durante o governo Fox.

A Constituição mexicana, ao reservar ao Estado o direito exclusivo de explorar recursos do subsolo, representa uma importante barreira a políticas de integração energética, liberalização e à participação de investimento estrangeiro no setor de hidrocarbonetos. A situação é semelhante no setor elétrico, uma vez que também é assegurado constitucionalmente o monopólio estatal sobre geração, transmissão e distribuição de energia, administrado pela Comisión Federal de Electricidad (CFE).

Visando abrir caminho para uma maior abertura desses setores, o governo Fox apresentou à Câmara dos Deputados, em agosto de 2002, uma proposta de reforma energética, com foco no setor elétrico. $\mathrm{O}$ PRD se mostrou contrário à proposta e mesmo o PRI, que reconhecia a importância de modificações no setor, reconheceu que a reforma, tal qual fora apresentada, implicaria em uma marginalização das empresas estatais frente às empresas estrangeiras, o que motivou a paralisação do projeto no Congresso.

Em 2005, o governo Fox apresentou uma nova proposta de reforma, desta vez no setor de hidrocarbonetos, envolvendo petróleo e gás. Esta última tocava em um ponto delicado, a PEMEX (Petróleos Mexicanos), símbolo do nacionalismo mexicano e grande fonte de renda para o governo. O PRI declarou-se contrário à privatização da PEMEX e o projeto permaneceu congelado no Congresso.

Para Purcell (2004), a escolha do formato de acordo executivo para a ASPAN não foi meramente casual, mas fruto da percepção dos Estados Unidos de que o Congresso mexicano é obstrucionista, ao ter se recusado a aprovar as reformas estruturais propostas pelo Executivo para a liberalização do setor energético no México. 
O governo Fox, não conseguindo obter as mudanças constitucionais necessárias para a reforma no setor energético e pressionado para a abertura do setor por parte dos Estados Unidos, optou pela estratégia de negociação da ASPAN nos marcos de um acordo executivo, ao invés de um tratado, que poderia encontrar fortes resistências no Senado quando submetido à votação.

A constituição da ASPAN no formato de um acordo executivo ilustra uma manobra utilizada pelo governo Fox para excluir da apreciação do Congresso, em especial do Senado, temas de política externa com um forte viés de politização doméstica. 


\section{CAPÍTULO 4 - ENCAMINHAMENTOS PARAA AMPLIAÇÃO DA AGENDA DE PESQUISA: POSSÍVEIS FATORES QUE LIMITAM A ATUAÇÃO DO CONGRESSO MEXICANO NA FORMULAÇÃO DE POLÍTICA EXTERNA}

Ao refletir sobre os fatores que representam limitações à atuação do Congresso mexicano na formulação de política externa, houve uma preocupação que a pesquisa se afastasse das abordagens tradicionais sobre o tema, as quais tendem a enfatizar aspectos como a pequena expertise dos legisladores em temáticas internacionais ou mesmo o peso do domínio histórico do Executivo sobre essa seara.

Tais variáveis, embora não possam ser desconsideradas, pouco contribuem para o enriquecimento do debate, na medida em que assumiram o status de verdadeiros postulados na literatura, reproduzidos de forma sistemática, mas com raros trabalhos empíricos que buscassem confirmar o real peso de tais fatores sobre o desempenho do Legislativo.

Com este escopo, a idéia é traçar um diagnóstico das limitações do Congresso à luz de construções teóricas mais sofisticadas, como o conceito de Tsebelis de veto player e os fatores para alteração de uma política pública, e o modelo de Milner sobre o papel desempenhado pela estrutura da política doméstica na aprovação ou rejeição de um tratado internacional. Agregamos a esses modelos consagrados, também como fatores explicativos, algumas especificidades da realidade mexicana, como o impacto da assinatura do NAFTA sobre a percepção a respeito dos acordos comerciais que se seguiram e o novo comportamento do Legislativo em um cenário de democratização e governo dividido.

Durante o processo de pesquisa, não foram encontrados trabalhos que apresentassem este tipo de abordagem. Os autores consultados se limitam a diagnosticar uma baixa capacidade institucional do Congresso mexicano em exercer um contrapeso efetivo às ações do Executivo, sem se aprofundar em condicionantes que justificariam esta debilidade institucional.

Esta é a razão pela qual optamos por designar o presente de capítulo de "encaminhamentos para uma nova agenda de pesquisa". Longe de apresentar uma análise exaustiva sobre o tema, assumimos uma pretensão mais modesta de apenas pontuar 
alguns fatores que foram nos ocorrendo no decorrer do processo de pesquisa, os quais quiçá possam servir de parâmetros para pesquisas futuras.

Desde já, assumimos o risco de que o diagnóstico traçado possa ser precoce, haja vista que parte das limitações apontadas pode ser fruto de um processo de acomodação das estruturas democráticas mexicanas. Apenas duas das quatro legislaturas estudadas representam, de fato, uma situação de governo dividido. Portanto, a análise recaiu sobre as primeiras manifestações do Congresso sobre temas internacionais em um cenário em que o Executivo não dispunha de maiorias nas Casas Legislativas.

Neste ponto, talvez tenha certa valia o argumento do peso do domínio histórico do Executivo sobre a formulação de política externa, para justificar que o Congresso necessite de um tempo maior nesta seara para se firmar como um contraponto ao Executivo, quando, em âmbito doméstico, em razão das próprias limitações de controle de agenda impostas pelo desenho do sistema político mexicano, o Legislativo assumiu desde logo uma postura mais assertiva e se firmou como o principal produtor de leis no país.

\section{A APROVAÇÃo dOS TRATADOS INTERNACIONAIS E OS CUSTOS DA REJEIÇÃO}

A principal faculdade do Senado mexicano em matéria de política externa é a aprovação dos tratados internacionais, que lhe confere um poder de veto efetivo sobre as ações do Executivo. O tratado deve ser aprovado por maioria simples na Câmara Alta, a qual não pode emendá-lo, apenas apresentar reservas ou entendimentos em relação a determinados dispositivos.

O poder ratificador constitucionalmente atribuído ao Senado permite defini-lo, segundo a nomenclatura de George Tsebelis (1997), como o único ponto de veto institucional no processo de aprovação de tratados internacionais no sistema político mexicano, isto é, o único ator, além do Executivo, cuja concordância é requerida para a mudança de uma determinada política, sendo composto por 128 membros. O autor destaca dois tipos de veto players: os institucionais, cuja competência está fixada na Constituição, e os partidários, cuja prerrogativa de veto decorre da própria articulação do jogo político. 
Tsebelis se propõe a demonstrar que a estabilidade das políticas públicas de um determinado sistema político varia em função de três características fundamentais de seus veto players: o seu número, sua congruência (diferença entre as posições políticas) e sua coesão (similaridades das posições políticas das unidades que os constituem). Quanto maior o número de pontos de veto e menor a congruência e coesão entre os atores políticos, menores são as chances de alteração das políticas vigentes (status quo).

No caso mexicano, além do reduzido número de pontos de veto no processo de ratificação dos tratados internacionais - a Câmara dos Deputados, por exemplo, não detém qualquer faculdade constitucional que permita sua ingerência no processo como ponto de veto - também o comportamento das variáveis congruência e coesão tem favorecido o êxito do Executivo na aprovação dos instrumentos internacionais por ele firmados.

Os partidos mexicanos com representação no Senado, em que pese algumas manifestações em sentido contrário, sobretudo de membros do PRD, têm se mostrado favoráveis à aprovação de tratados de livre comércio (Mena, 2006), em congruência com as posições do Executivo. A esses fatores soma-se a coesão partidária, uma das características do sistema político mexicano segundo consenso na literatura, fruto da conjugação entre a força das legendas e as lideranças partidárias.

Além das contribuições de Tsebelis, o modelo de dois níveis de Milner (1997), desenvolvido a partir de referenciais da teoria dos jogos, permite-nos compreender melhor o papel desempenhado pela estrutura da política doméstica sobre a aprovação ou rejeição de um tratado internacional. O jogo proposto pela autora ilustra uma situação de governo dividido, isto é, em que o Executivo não possui maiorias no Congresso, amoldando-se ao contexto político do sexênio do governo Fox.

Em uma situação de informação completa e simétrica, o jogo é composto por três atores: o país estrangeiro (f), tratado como um ator unitário, o Executivo nacional (p), representado pelo Presidente, e o partido mediano no Congresso (c). A representação gráfica é elucidativa: 




Fonte: Milner, 1997:78

A rejeição de um tratado internacional pode ser entendida como uma posição extrema do status quo, isto é, em que $q>(2 c-p)$, de forma que $p$ será o equilíbrio, prevalecendo o ponto ideal do Executivo nacional. Quanto mais distante do ponto ideal do partido mediano do Congresso (c) estiver o status quo, a influência do Legislativo sobre as negociações tende a se enfraquecer (idem, 1997). Quando o status quo assume um valor extremo, distanciando-se em excesso do ponto ideal do partido mediano, a não aprovação do acordo torna-se muito custosa, e os negociadores encontrarão poucos constrangimentos à sua ação, pois a ameaça do partido mediano de escolher o status quo, rejeitando o acordo, não é crível.

À medida que o status quo se torna muito extremo, o Executivo ganha influência em virtude de seu poder de iniciar a agenda e o jogo doméstico, ou seja, a situação de governo dividido perde importância para a aprovação de um tratado. $\mathrm{O}$ acordo ideal para o Executivo é preferido pelo partido mediano à rejeição do tratado, e o acordo final será resultado das negociações entre os Executivos dos países signatários. 
Quando o tratado é submetido à apreciação dos congressistas, o partido mediano analisa os custos decorrentes do descumprimento pelo país dos compromissos assumidos, tolerando, na maior parte dos casos, políticas que estejam além da sua curva de indiferença, já que a manutenção do status quo é muito custosa.

A inovação do modelo de Milner consiste em introduzir uma variável importante no jogo político de aprovação de um instrumento internacional: o cálculo dos congressistas sobre o custo de rejeição pelo país dos compromissos assumidos internacionalmente, o que aumenta a chance de ratificação ${ }^{52}$. Portanto, o êxito do Executivo na aprovação de tratados pode ser explicado não apenas pelo apoio dos partidos a essa acordo, por sua coesão interna, mas também pelos custos elevados de sua rejeição, que pode acarretar sanções internacionais para o país.

\section{O IMPACTO DO NAFTA E OS EFEITOS DECRESCENTES DOS TRATADOS APÓS A ABERTURA ECONÔMICA}

O México é um dos países com maior número de tratados de livre comércio assinados, frutos de um agressivo processo de abertura econômica iniciado nos anos 80 , o qual buscava alavancar a economia a partir do abandono do sistema protecionista de substituição de importações em nome do desenvolvimento de um modelo calcado no livre comércio.

Embora antecedida por algumas medidas do governo visando à inserção do México no comércio internacional, a constituição da Área de Livre Comércio da América do Norte (NAFTA) é considerada a pedra de toque desse amplo processo de liberalização econômica realizado pelo país. A assinatura do NAFTA representou a institucionalização das relações econômicas com o principal parceiro econômico do país, os Estados Unidos, com os quais o México mantém 3/4 do seu fluxo comercial.

Escapa aos propósitos desse trabalho desenvolver uma ampla discussão sobre os aspectos positivos ou negativos da adesão ao NAFTA. Interessa-nos o ponto de consenso na literatura sobre o tema, isto é, de que a entrada do México no Tratado de Livre

\footnotetext{
${ }^{52}$ Observação semelhante é feita por Maria Regina Soares de Lima e Fabiano dos Santos, os quais, utilizando um modelo linear mais simplificado, apontam que, caso o Congresso rejeite o acordo, é bem provável que o país incorra nos custos decorrentes de sanções (Lima e Santos, 2001:131).
} 
Comércio da América do Norte produziu impactos significativos sobre a economia e a sociedade do país, a ponto de tornar o acordo o eixo central ao redor do qual se desenvolveu todo seu processo de liberalização econômica.

A razão para a centralidade que o NAFTA assumiu para o México reside na presença dos Estados Unidos como uma das partes signatárias, cuja proximidade geográfica com o país fez com que, historicamente, os vínculos entre mexicanos e norteamericanos permanecessem fortes.

Após a adesão ao NAFTA, o México assinou outros 79 instrumentos internacionais de liberalização econômica ${ }^{53}$, incluindo tratados de livre comércio, de investimentos e de cooperação econômica e financeira, tendo como parceiros os mais diversos países, a exemplo de Bolívia, Chile, Costa Rica, Colômbia, Venezuela, Brasil, Argentina, Nicarágua, membros da União Européia e Israel. Todos esses tratados foram ratificados pelo Senado e apenas em relação a uma pequena parcela deles a aprovação não foi unânime.

$\mathrm{O}$ argumento aqui desenvolvido é que, no caso mexicano, o impacto produzido pela constituição do NAFTA, feita à revelia da participação do Legislativo, sobre o país foi de tal monta, gerando uma intensificação sem precedentes do processo de abertura econômica iniciado na década anterior, que a percepção dos congressistas sobre os efeitos dos tratados de livre comércio que se seguiram foi progressivamente decrescente.

Em outras palavras, face à abertura abrupta produzida pelo NAFTA, os impactos dos tratados assinados posteriormente foram percebidos como de menor importância, a ponto de não gerar grande resistência no interior do Congresso em relação à sua aprovação, ou ainda, em alguns casos, estes foram percebidos como o único meio de fazer contrapeso à dependência criada pelo NAFTA em relação aos Estados Unidos, o que motivou o apoio do Legislativo.

Uma ressalva a este raciocínio deve ser feita em relação aos Acordos para Proteção de Investimentos Recíprocos (APRI’s), cuja aprovação encontrou maior resistência por parte dos congressistas, sobretudo do PRD, que os definiam como um instrumento de proteção excessiva ao investimento estrangeiro, em detrimento da

\footnotetext{
${ }^{53}$ Ver gráfico com a distribuição por tema dos tratados internacionais apresentados para ratificação no Senado ao longo das legislaturas estudadas.
} 
indústria nacional. A resistência não foi suficiente para colocar em risco a aprovação dos acordos, os quais, na estratégia do governo, davam continuidade e sustentação ao processo de abertura econômica.

A proximidade das negociações em torno do capítulo agrícola do NAFTA em 2004, associada ao desempenho econômico do país abaixo do esperado e ao comprometimento da indústria nacional, suscitaram discussões no interior da sociedade mexicana sobre os reais benefícios trazidos pela abertura econômica, em especial pelo acordo entre os países da América do Norte. Este novo cenário pode ser considerado um ponto de viragem na postura dos congressistas, que, na esteira das demandas sociais, passaram a colocar em xeque todos os tratados de abertura comercial.

Como manifestação desta nova postura, já no Governo Calderón, em novembro de 2008, um dos líderes do Senado recomendou ao Executivo que não assinasse um acordo de livre comércio com a Coréia do Sul, advertindo que nenhum tratado seria aprovado pela Câmara Alta enquanto a competitividade da indústria nacional não fosse recuperada.

\section{A DifiCULDADE DE CONSTRUÇão DE CONSENSO NO INTERIOR DAS CASAS LEGISLATIVAS SOBRE O PAPEL DO CONGRESSO EM POLÍTICA EXTERNA}

Conforme destacado no capítulo anterior, foi sobretudo durante o Governo Fox que o Congresso se apresenta como um ator disposto a disputar espaço na arena de formulação e desenvolvimento da política externa. Em que pese o anseio de fazer frente ao Executivo, em especial diante das mudanças de orientação promovidas por Fox, as quais iam de encontro aos cânones tradicionais da política externa mexicana, uma maior assertividade do Legislativo em suas ações encontrou entraves na dificuldade de construção de consensos a respeito de qual deveria ser seu papel nesta seara.

A análise das iniciativas sobre legislação procedimental apresentadas nas Legislaturas LVI a LIX revela um primeiro ponto de divergência: a divisão de atribuições em matéria internacional entre as Casas Legislativas. De um lado, no interior do Senado, existe um movimento no sentido de ampliar ao máximo as atribuições da Câmara Alta, a quem caberia o mandato constitucional de guarda da atuação internacional do país, por 
meio da diversificação dos mecanismos de controle e de aumento das matérias submetidas à sua aprovação.

De outro, na Câmara dos Deputados, a concentração das atribuições no Senado gera grande desconforto entre os deputados, que consideram que a Câmara Baixa deve ter seu papel reconhecido e ampliado nesta área, chegando ao extremo de alguns projetos proporem a transferência do controle dos atos internacionais para a sua alçada. Concomitantemente, existe grande resistência na aprovação de iniciativas que visem ampliar as faculdades do Senado, consoante se observa na votação da Lei sobre Aprovação de Tratados Internacionais em Matéria Econômica.

As inúmeras propostas de reforma das duas principais leis que regem a aprovação de instrumentos internacionais, a Lei sobre a Celebração de Tratados Internacionais e a Lei sobre a Aprovação de Tratados Internacionais em Matéria Econômica, são reflexos do descontentamento em torno dos mecanismos existentes de controle sobre as ações do Executivo.

Contudo, estas traduzem um segundo ponto de divergência: quais seriam os mecanismos mais eficientes de controle das ações internacionais. As propostas se orientam, em parte, para o controle de conteúdo, fixando parâmetros que devem ser observados quando da assunção de compromissos internacionais, e, em parte, para a supervisão das etapas do processo de negociação por sistemas de consulta e fornecimento de relatórios de avanço das tratativas.

Um terceiro ponto de divergência refere-se à existência ou não de temáticas que devam ser conduzidas preferencialmente pelo Executivo, sem a ingerência direta do Legislativo, que se limitaria a eventual controle de excessos, a fim de evitar que as dificuldades do jogo político prejudiquem uma ação mais efetiva do país. As propostas neste sentido visam retirar do controle legislativo temas, por exemplo, como o pedido do Presidente da República para se ausentar do país por curto período de tempo ou ainda a aprovação dos acordos executivos e institucionais, mas encontram grande resistência por parte dos congressistas.

Por fim, o quarto ponto de divergência sobre o papel do Congresso na área internacional guarda relação com o exercício dos meios indiretos de influência, em especial com o controle sobre os impostos e o orçamento, os quais podem ser utilizados 
de maneira incidental para afetar a política externa mexicana. A taxação do xarope de milho representa um caso emblemático de uso de tais prerrogativas pela Câmara dos Deputados, a qual encontrou certa resistência, sobretudo de congressistas do partido do governo, no interior do Senado.

Portanto, parte da debilidade institucional do Congresso apontada pela literatura pode ser atribuída aos problemas em torno da construção de consensos sobre o papel a ser desempenhado pelo Legislativo na política externa, os instrumentos a ele inerentes, os limites de seu exercício, bem como a correta distribuição de faculdades entre as Casas Legislativas.

\section{O USO DOMÉSTICO DAS ATRIBUIÇÕES DO CONGRESSO}

O uso doméstico das atribuições do Congresso mexicano em matéria de política externa foi apontado por Velazquez (2007), para quem a mobilização dos congressistas em torno de assuntos internacionais se tornou um aspecto fundamental da política doméstica do país; e, de maneira indireta, por González (2005), que definiu o Legislativo como uma verdadeira caixa de ressonância, que não logrou conforma-se como um contrapeso efetivo ao Executivo.

As primeiras manifestações do Congresso sobre temáticas internacionais, longe de refletirem uma preocupação com a construção de uma política externa de Estado, pautada pelos princípios de relações internacionais estampados na Constituição mexicana, são fruto da percepção dos congressistas de que a repercussão angariada por determinados temas converteu a política externa em um domínio a mais de disputa por espaços políticos internos.

O pano de fundo dos confrontos do Congresso com Fox foi a busca de espaços de poder que foram surgindo com o avanço do processo de democratização e com o contexto político de governo dividido. Os legisladores de oposição utilizaram as críticas dirigidas ao Presidente Fox, que tinham como bandeira o desrespeito aos cânones tradicionais da política externa mexicana, para ganhar apoio interno e fortalecer o papel do Congresso como a "caixa de ressonância" das demandas sociais. Em sentido oposto, Fox usava a postura agressiva de crítica do Congresso como uma forma de minar a sua legitimidade 
na formulação da política externa, enfatizando que a obstrução às ações do Executivo comprometia a imagem do país perante a comunidade internacional.

Neste confronto, saiu-se vitorioso o Presidente Fox que, a despeito das fortes pressões internas do Congresso, conseguiu isolar parte do efeito doméstico sobre a política externa do seu governo, desenvolvendo diversas ações contrárias às preferências dos congressistas. O uso doméstico da política externa pelo Legislativo se, de um lado, consolidou sua situação como caixa de ressonância de demandas, de outro, ampliou a margem de manobra do Presidente Fox, que buscou diminuir os espaços de influência dos congressistas, concentrando o debate internamente, para ter mais liberdade para atuar no plano internacional. 


\section{CONCluSÃo}

\section{ATUALIZANDO O DEBATE: BREVES CONSIDERAÇÕES SOBRE OS DOIS PRIMEIROS ANOS DO GOVERNO FELIPE CALDERÓN (2007-2008)}

Felipe Calderón assumiu a presidência do México em um contexto político bastante conturbado e herdou de seu antecessor, Vicente Fox, algumas problemáticas internacionais de difícil solução. Segurança, economia, imigração e a relação com os países latino-americanos continuaram como temas centrais da agenda mexicana, cuja condução gerou, desde o início do novo governo, atritos com o Congresso.

Durante a campanha eleitoral, Calderón apresentou sua visão sobre política externa em um discurso proferido em 28 de março de 2006, no qual enfatizou a necessidade de desenvolver uma política "ativa e responsável" elaborado em conjunto com seus conselheiros políticos, destacou três aspectos do cenário internacional com grande influência sobre o curso da política externa mexicana: a) o debate político e ideológico sobre segurança nacional no México e nos Estados Unidos após os eventos de 11 de setembro; b) o debate em torno dos benefícios e desvantagens da globalização e da democracia; c) a geopolítica e a segurança internacionais, com destaque para a atuação de Índia e China ${ }^{55}$.

Uma vez eleito, o novo Presidente incluiu em seu Plano de Desenvolvimento Nacional 2007-2012 (PND) ${ }^{56}$ um capítulo sobre "Democracia Efetiva e Política externa responsável", no qual define a política externa como uma "plataforma para promover o desenvolvimento humano sustentável", aumentando a qualidade de vida dos mexicanos. Em seu PND, Calderón reconhece a importância dos princípios constitucionais de política exterior.

O objetivo central da política externa mexicana seria aproveitar a globalização para se tornar um país desenvolvido, capaz de perseguir seus interesses nacionais,

\footnotetext{
${ }^{54}$ Disponível em: http://www.felipe.org.mx/felipeCalderon/Sala+de+Prensa/Boletines/ 2006/Marzo/bol_ 28_03_06.htm. Acesso em 07.02.2009.

${ }_{55}$ Disponível em http://www.felipe-calderon.org/propuesta. Acesso em 07.02.2009.

${ }^{56}$ Disponível em http://www.pnd.calderon.presidencia.gob.mx. Acesso 10.02.2009.
} 
mantendo sua identidade cultural, em um ambiente de paz. O documento destaca 12 objetivos de política externa:

1) Impulsionar o desenvolvimento nacional a partir da projeção de uma imagem positiva do México para o mundo;

2) Posicionar o México na esfera internacional;

3) Fortalecer as relações políticas e econômicas com a América Latina e Caribe;

4) Expandir e fortalecer os mecanismos políticos de cooperação com os Estados Unidos e Canadá;

5) Progredir na proteção e na defesa dos direitos humanos fora do território mexicano;

6) Contribuir em ações multilaterais nas Nações Unidas e nas organizações internacionais;

7) Aprofundar as relações com Europa, Ásia do Pacífico, África e Oriente Médio;

8) Fazer reformas para harmonizar a legislação nacional com as convenções internacionais ratificadas pelo México;

9) Participar ativamente na cooperação internacional para o desenvolvimento;

10) Buscar novas formas de cooperação bilateral e multilateral no campo da segurança;

11) Defender a democracia, a liberdade, os direitos humanos e o desenvolvimento sustentável;

12) Aumentar a capacidade do serviço diplomático mexicano de defender seus interesses nacionais.

Logo nos três primeiros meses de governo, a política externa de Calderón foi alvo de críticas dos deputados do PRI e do PRD, os quais acusaram o Presidente de dar continuidade às negociações da ASPAN sem a aprovação do Congresso. Nas palavras de um deputado do PRI, a ASPAN constitui "uma aliança implícita com os setores 
neoconservadores dos Estados Unidos e é contrária ao artigo 89 da Constituição e às tradições diplomáticas do México" ${ }^{\text {"57 }}$.

Antes da realização da IV Reunião de Cúpula dos Líderes da ASPAN, em abril de 2008, os deputados do PRD divulgaram um boletim de imprensa ${ }^{58}$, exigindo que o Executivo Federal: 1) interrompesse imediatamente as negociações e implementação dos acordos da ASPAN, até que sejam integrados à discussão todos os setores representativos da nação mexicana e que o processo de negociação seja submetido à supervisão do Congresso da União; 2) não reconheça a representatividade do Conselho de Competitividade da América do Norte (CCAN), pois não reflete os interesses dos povos da região, mas sim o desejo de privatização de riquezas do povo como o petróleo; 3) estabeleça uma agenda ampla de discussão com o Congresso mexicano e a sociedade civil, para que se definam os termos da relação com o Canadá e os Estados Unidos, tendo como prioridade a imigração, o desenvolvimento regional e o estabelecimento de fundos compensatórios; 4) seja discutido, no marco do diálogo nacional sobre reforma energética, o tema das negociações sobre "segurança energética” incluído na ASPAN.

Também no âmbito da segurança, em 22 de outubro de 2007, através da "Iniciativa de Mérida: um novo paradigma para a cooperação em segurança", o governo Calderón firmou com os Estados Unidos um compromisso de desenvolver ações bilaterais para o combate ao tráfico de drogas e ao crime organizado na fronteira entre os países. As decisões de Calderón no âmbito da ASPAN e da Iniciativa têm despertado a preocupação dos congressistas mais conservadores.

$\mathrm{Na}$ seara econômica, o descontentamento com o NAFTA parece ser a principal questão a ser enfrentada pelo governo mexicano. O tratado de livre comércio conduziu o país na contramão do processo revolucionário e as ações de política externa que utilizaram o acordo como plataforma para o desenvolvimento econômico mexicano não tiveram o êxito esperado. Como resultado, PRI e PRD culpam o NAFTA pela crise agrícola no México.

\footnotetext{
${ }^{57} \mathrm{La}$ jornada, 26 de fevereiro de 2007, disponível em http://www.jornada.unam.mx/2007/02/26/index.php?section=politica\&article=005n1pol. Acesso em 01.09.2009.

${ }^{58}$ Disponível em http://www.rmalc.org.mx/aspan/misc/posicion_dip_prd_cumbre_aspan.htm. Acesso em 01.09.2009.
} 
A insatisfação com o Tratado de Livre Comércio da América do Norte conduziu a questionamentos sobre os reais benefícios de todo o processo de abertura econômica do país. Em novembro de 2008, o Presidente da Comissão de Fomento Industrial do Senado da República, Eloy Cantú Segovia, advertiu que não se aprovariam mais acordos comerciais por recomendações do exterior e recomendou ao governo de Felipe Calderón que não assinasse o Acordo de Livre Comércio com a Coréia do Sul. De acordo com o senador, "nenhum tratado de livre comércio passará no Senado até que a indústria eleve a sua competitividade e, para tal, é necessário elevar os impostos com o fim de proteger a planta produtiva"59.

Ao lado da economia, a política migratória continua a ser objeto de preocupação. O governo mexicano tem interesse na assinatura de um acordo de imigração que reconheça o status legal dos mexicanos que já estão em território americano e garanta a proteção de seus direitos humanos.

No início de 2008, o Senado aprovou com 70 votos a favor e 14 abstenções uma autorização de viagem do Presidente Felipe Calderón, para visitar, a partir de 10 de fevereiro, por cinco dias, Nova Iorque, Chicago, Boston, Los Angeles e Sacramento, em uma tentativa de estreitar os laços com a comunidade mexicana nesses estados. A votação é compatível com a preocupação dos partidos políticos de que poucas ações estão sendo desenvolvidas na área de imigração. As abstenções demonstraram certa hesitação quanto à utilidade de uma viagem durante a campanha presidencial nos Estados Unidos (Dávila, 2006).

A exemplo do ocorrido no governo Fox, Calderón também se envolveu em incidentes diplomáticos com os países latino-americanos. No Fórum Econômico Mundial, o Presidente fez declarações contra a Bolívia e Venezuela em virtude da decisão desses países de nacionalizar algumas de suas indústrias. O PRI imediatamente formou uma Comissão de Monitoramento de Política Externa, a fim de evitar que Calderón adotasse outras medidas que pudessem causar conflitos diplomáticos com outros países.

\footnotetext{
${ }^{59}$ BECERRIL, Isabel. "Chocan los Legisladores y gobierno sobre TLC com Corea del Sur”, el Financeiro, 11 de novembro $\quad$ de $\quad 2008, \quad$ disponível $\quad$ em http://www.elfinanciero.com.mx/ElFinanciero/Portal/cfpages/contentmgr.cfm?docId=155361\&docTipo=1 \&orderby=docid\&sortby=ASC
} 
Para Dávila (idem), ao longo dos dois primeiros anos da administração de Calderón, os partidos se focaram no debate de assuntos internos, tais como reforma fiscal, reforma nas finanças públicas e o uso da reforma energética, e não se preocuparam muito com a política externa. "A política externa foi conduzida de maneira discreta", mesmo os episódios mais complicados, como as crises com o Equador e a Colômbia, foram administrados de maneira tática (Dávila, 2006:12).

As tabelas abaixo ilustram os dados sobre a atividade do Congresso desde a posse de Felipe Calderón, em 01 de dezembro de 2006, até o término da LX Legislatura, em 31 de agosto de 2009. As taxas elevadas de aprovação de instrumentos internacionais, pedidos de viagem, nomeações diplomáticas e permissões para o uso de condecoração seguem a tendência observada nas legislaturas anteriores.

Tabela 26 - Ratificacões pelo Congresso na LX Legislatura - 01.12.2006 a

$\underline{31.08 .2009} 9^{60}$

\begin{tabular}{|l|l|l|l|l|l|}
\hline & Apresentados & Aprovados & Pendentes & Rejeitados & Taxa de aprovação \\
\hline $\begin{array}{l}\text { Instrumentos } \\
\text { Internacionais }\end{array}$ & 60 & 55 & 5 & 0 & $91,66 \%$ \\
\hline $\begin{array}{l}\text { Autorização } \\
\text { de viagem }\end{array}$ & 21 & 20 & 1 & 0 & $95,23 \%$ \\
\hline $\begin{array}{l}\text { Ratificação de } \\
\text { nomeações } \\
\text { diplomáticas }\end{array}$ & 25 & 25 & 0 & 0 & $100,00 \%$ \\
\hline $\begin{array}{l}\text { Permissão } \\
\text { para o uso de } \\
\text { condecoração }\end{array}$ & 14 & 14 & 0 & 0 & $100,00 \%$ \\
\hline
\end{tabular}

Fonte: Sistema de Informação Legislativa do Governo Mexicano

As iniciativas apresentadas pelo Congresso nos primeiros anos do governo Calderón em matéria de relações exteriores tinham por objeto: a) uma nova Lei Geral sobre Celebração e Aprovação de Tratados Internacionais, que derrogaria os dois diplomas legais em vigor sobre a matéria; b) alterações na lei de serviço exterior mexicana; c) lei para conservar a neutralidade do país; d) lei de cooperação internacional

\footnotetext{
${ }^{60}$ O período de coleta de dados das tabelas abrange do início do governo de Felipe Calderón, o qual tomou posse em 01 de dezembro de 2006, até o final da LX Legislatura.
} 
para o desenvolvimento; e) lei para regular o envio de remessas do exterior para o México; f) alterações nas faculdades constitucionais do Senado e da Câmara dos Deputados; g) modificações no processo de nomeação e ratificação dos agentes diplomáticos.

Não obstante a importância de diversos temas abordados nos projetos de lei, as sete iniciativas aprovadas versavam sobre aspectos de menor importância, a exemplo de emendas aos convênios constitutivos da Associação Internacional de Fomento e da Corporação Internacional de Investimentos e reformas no Código Federal de Procedimentos Civis. Questões mais controvertidas, como a votação de uma nova lei sobre a aprovação de tratados internacionais, ainda estão pendentes de apreciação pelo plenário. Nenhuma iniciativa sobre aspectos procedimentais foi votada.

Tabela 27 - Iniciativas em matéria de relacões exteriores na LX Legislatura $\underline{01.12 .2006}$ a 31.08.2009

\begin{tabular}{|l|l|l|l|l|l|}
\hline $\begin{array}{c}\text { Tipo de } \\
\text { iniciativa }\end{array}$ & Apresentadas & Aprovadas & Pendentes & Rejeitadas & Taxa de aprovação \\
\hline Substantiva & 44 & 7 & 32 & 5 & $15,90 \%$ \\
\hline Procedimental & 15 & 0 & 15 & 0 & ------------- \\
\hline Total & 59 & 7 & 47 & 5 & $11,86 \%$ \\
\hline
\end{tabular}

Fonte: Sistema de Informação Legislativa do Governo Mexicano

O número de pontos de acordo acompanhou a tendência de crescimento observada desde o início do processo de democratização no país. Em pouco mais de dois anos e meio, foram apresentadas 413 proposições com pontos de acordo sobre temáticas internacionais, a maioria delas na modalidade "censura e exortações ao Executivo", traço de um Congresso mais demandante em relação ao Presidente da República e às diretrizes de condução da política externa.

Os pontos de acordo aprovados durante o período destacado versaram sobre: a) a reforma na legislação imigratória dos Estados Unidos e a situação dos imigrantes mexicanos ilegais; b) a Iniciativa de Mérida; c) a Associação para a Segurança e Prosperidade da América do Norte (ASPAN); d) assinatura de um tratado de livre comércio entre México, Peru, Austrália e Coréia; e) o embargo econômico a Cuba e o estreitamento das relações diplomáticas com a Ilha; f) participação do México como 
membro permanente no Conselho de Segurança da ONU; g) avanço do processo de negociação do NAFTA.

Merece destaque o expressivo número de pontos de acordo sobre a Iniciativa de Mérida, ora protestando contra o acordo, ora demandando informações do Executivo sobre o avanço das negociações e os termos para o recebimento de ajuda dos Estados Unidos. Os pontos de acordo sobre a ASPAN traduziram preocupação semelhante. Ao lado do tema da segurança, também a imigração foi objeto de grande quantidade de pontos de acordo, reforçando o interesse dos congressistas em relação a alguns temas latentes da agenda bilateral com os Estados Unidos.

Tabela 28 - Pontos de Acordo em matéria de relacões exteriores apresentados na $\underline{\text { LX Legislatura - 01.12.2006 a 31.08.2009 }}$

\begin{tabular}{|c|c|c|c|c|c|}
\hline & Apresentados & Aprovados & Pendentes & Rejeitados & $\begin{array}{c}\text { Taxa de } \\
\text { aprovação }\end{array}$ \\
\hline $\begin{array}{c}\text { Censuras/ } \\
\text { exortações ao } \\
\text { Executivo }\end{array}$ & 227 & 156 & 47 & 24 & $68.72 \%$ \\
\hline $\begin{array}{c}\text { Pedidos de } \\
\text { comparecimento }\end{array}$ & 23 & 17 & 4 & 2 & $73,91 \%$ \\
\hline $\begin{array}{c}\text { Pedidos de } \\
\text { informação ao } \\
\text { Executivo }\end{array}$ & 31 & 22 & 7 & 2 & $70,96 \%$ \\
\hline $\begin{array}{c}\text { Criação de } \\
\text { comissões ou } \\
\text { grupos de } \\
\text { trabalho }\end{array}$ & 7 & 3 & 4 & 0 & $42,85 \%$ \\
\hline $\begin{array}{c}\text { Exorto/solicitaçã } \\
\text { o ao Legislativo }\end{array}$ & 52 & 22 & 19 & 11 & $42,30 \%$ \\
\hline Outros & 73 & 56 & 12 & 5 & $76,71 \%$ \\
\hline Total & 413 & 276 & 93 & 44 & $66,82 \%$ \\
\hline
\end{tabular}

Fonte: Sistema de Informação Legislativa do Governo Mexicano 
Tabela 29-Acordos Parlamentares em matéria de relacões exteriores apresentados na LX Legislatura - 01.12.2006 a 31.08.2009

\begin{tabular}{|c|c|c|c|c|c|}
\hline & Apresentados & Aprovados & Pendentes & Rejeitados & $\begin{array}{c}\text { Taxa de } \\
\text { aprovação }\end{array}$ \\
\hline $\begin{array}{c}\text { Criação de } \\
\text { comissões ou } \\
\text { grupos de trabalho }\end{array}$ & 0 & 0 & 0 & 0 & - \\
\hline $\begin{array}{c}\text { Censuras/ } \\
\text { exortações ao } \\
\text { Executivo }\end{array}$ & 1 & 1 & 0 & 0 & $100 \%$ \\
\hline $\begin{array}{c}\text { Pedidos de } \\
\text { comparecimento }\end{array}$ & 1 & 1 & 0 & 0 & $100 \%$ \\
\hline $\begin{array}{c}\text { Pedidos de } \\
\text { informação ao } \\
\text { Executivo }\end{array}$ & 0 & 0 & 0 & 0 & \\
\hline Outros & 5 & 5 & 0 & 0 & $100 \%$ \\
\hline Total & 4 & 4 & 0 & 0 & $100 \%$ \\
\hline
\end{tabular}

Fonte: Sistema de Informação Legislativa do Governo Mexicano

Os pontos de convergência de Calderón com os partidos políticos basicamente se referem ao aprimoramento da situação internacional do México, mediante expansão das relações com Europa, Ásia do Pacífico e Oriente Médio, e à condução de uma política externa calcada em princípios democráticos. Os principais pontos de discordância estão relacionados à condução das relações com a Venezuela e Cuba, à possibilidade de cooperação militar com os Estados Unidos e à participação do México no Conselho de Segurança da ONU, já que, na administração de Fox, o país participou deste órgão em 2003.

\section{CONSIDERAÇÕES FINAIS}

Nas últimas três décadas, o México experimentou um amplo processo de liberalização econômica, que representou o abandono do sistema protecionista de substituição de importações e a adoção de um modelo de desenvolvimento estruturado no livre comércio. As reformas internas no país em setores estratégicos foram acompanhadas pela adesão a organismos internacionais, como o GATT, antecessor da OMC, e pela 
assinatura de tratados de livre comércio com diversos países. Um momento determinante deste processo foi a assinatura, em 1994, do Tratado de Livre Comércio da América do Norte (NAFTA), que institucionalizou as relações do país com o seu principal parceiro comercial, os Estados Unidos.

O processo de liberalização foi fruto de um projeto encampado pelo PRI, que, pressionado pela crise econômica enfrentada pelo país, aderiu à plataforma de abertura proposta pelos negociadores da dívida externa do México. Aproveitando-se do rígido controle sobre as principais estruturas de poder no país, o partido do governo empreendeu as medidas necessárias, em âmbito interno e internacional, para a abertura econômica. Os principais setores da sociedade e até mesmo o Poder Legislativo foram alijados das tratativas, que se concentraram na figura do Presidente da República e nas burocracias ligadas ao Executivo, que se alternaram na disputa por espaços de poder.

A abertura capitaneada na seara econômica apontou as contradições em um país que, externamente, professava o livre comércio e, internamente, mantinha um regime autoritário sob o controle do Partido Revolucionário Institucional, que governou o país por mais de 70 anos.

No início da década de 80 do século passado, tiveram início os primeiros movimentos em prol da democratização do país, que mantinha eleições regulares para conferir aparência de legalidade ao regime vigente. O poder monolítico do PRI, aos poucos, apresentou as suas primeiras fissuras, fazendo com que alguns Presidentes, já na década de 90, sinalizassem para a abertura política como um processo inevitável.

As eleições de 1997 marcaram a perda pelo PRI, pela primeira vez na história mexicana, da maioria na Câmara dos Deputados. Nas eleições de 2000, o processo de democratização atingiu seu ponto mais alto, com a eleição de um candidato da oposição, o panista Vicente Fox, para a presidência, e o fim das maiorias do PRI na Câmara dos Deputados e no Senado.

Ao longo deste processo de abertura, o sistema político mexicano caminhou de um regime autoritário controlado por um único partido, no qual as demais legendas desempenhavam o papel de meras figurantes de uma aparente legitimidade, para um regime democrático, caracterizado por uma situação de governo dividido, com três grandes partidos disputando o poder, PRI, PAN e PRD. 
A democratização impulsionou os atores que estavam alijados do processo de tomada de decisão durante o regime autoritário a ingressarem na arena política de disputa por espaços de poder. Partidos políticos, entidades não governamentais, o Poder Legislativo, burocracias e grupos de interesses conformam esses novos atores, que alteraram a geometria do processo decisório, tornando-o mais poliárquico.

No campo da política externa, os processos de liberalização econômica e política produziram alterações não apenas de conteúdo, mas também na dinâmica da sua formulação. Modificações na agenda e na estrutura de prioridades, uma maior exposição da sociedade aos acontecimentos mundiais, impulsionando o ativismo da sociedade civil, e o rearranjo de forças no interior das burocracias do Executivo são apontados pela literatura como os traços marcantes das mudanças observadas.

A contribuição do presente trabalho reside em acrescentar um novo elemento à discussão: a possibilidade do binômio liberalização econômica e abertura política ter conduzido, na esteira dos argumentos de Maria Regina Soares de Lima e Fabiano dos Santos, a um maior ativismo do Congresso mexicano em temas de política externa.

$\mathrm{Se}$, do ponto de vista doméstico, existe certo consenso entre os autores de que a democratização e a situação de governo dividido abriram caminho para um maior protagonismo do Congresso, a ponto deste ter se tornado o principal propositor de leis aprovadas no México (Nacif, 2003), no âmbito da política externa o papel desempenhado pelo Legislativo Nacional tende a ser considerado mais modesto.

A primeira preocupação da pesquisa foi buscar variáveis que permitissem medir o comportamento do Congresso. A pergunta de partida, portanto, foi: o que faz o Congresso em política externa? A partir deste referencial, foram definidas, com base na linha de pesquisa de Henehan (2003), duas variáveis que serviram como preditores do comportamento do Congresso mexicano: a) nível de atividade, abrangendo todas as ações do Congresso relacionadas, direta ou indiretamente, com temas de política externa; b) nível de divergência, medido a partir das diferenças de posição dos partidos políticos mexicanos sobre temas de política externa, com reflexos diretos sobre as votações no interior do Congresso, e dos atritos entre Executivo e Legislativo.

Para definir as ações abrangidas pela variável nível de atividade, foram utilizados como parâmetros os meio de influência do Congresso descritos por Lindsay (1993), 
basicamente: a) legislação substantiva; b) antecipação de reações pelo Presidente; c) legislação procedimental; d) meios indiretos. Foram acrescentadas a este rol as atribuições fiscais e de orçamento (power of the purse) do Congresso, as quais podem afetar a política comercial, sobretudo através de tarifas. Até o mesmo o uso de taxas internas, como o tratamento fiscal privilegiado conferido aos refrigerantes que usavam açúcar local ao invés de xarope de milho importado, podem ter efeitos sobre a política exterior e foram consideradas na análise (Mena, 2006).

O nível de atividade do Congresso mexicano na produção de legislação substantiva e procedimental em matérias de política externa, se comparado à produção doméstica, ainda é baixo. Durante as quatro legislaturas estudadas, foram apresentadas 121 iniciativas substantivas, das quais 33 foram aprovadas, 49 estão pendentes de votação e 41 foram rejeitadas. As iniciativas versavam sobre temas variados, como a criação de um conselho nacional de política exterior, a renegociação do capítulo agropecuário do NAFTA e reformas na lei aduaneira e de comércio exterior. As propostas aprovadas tinham por objeto alterações no Código Penal Federal sobre o crime de terrorismo, procedimentos de desburocratização do comércio exterior e reformas na Lei de Serviço Exterior mexicana.

As iniciativas procedimentais, que se referem às atribuições do Congresso em matéria de política externa e os meios a elas inerentes, perfazem um total de 41 projetos, dos quais 4 foram aprovados, 29 permanecem pendentes de votação e 8 foram rejeitados. Das iniciativas aprovadas, merecem destaques dois instrumentos de grande importância no papel desempenhado pelo Congresso, especialmente no tocante à faculdade de ratificação de tratados internacionais: a Lei sobre a Celebração de Tratados Internacionais e a Lei sobre Aprovação e Celebração de Tratados Internacionais em matéria econômica, as quais ampliaram os mecanismos de controle do Legislativo sobre as negociações empreendidas pelo Executivo em âmbito internacional.

As propostas de alteração dos procedimentos no âmbito da política externa revelam não apenas o nível de atividade e, de forma incidental, o interesse do Congresso em ampliar as atribuições nesta seara e regulamentar os mecanismos já existentes, como também as diferenças nas iniciativas e as dificuldades de aprovação traduzem uma falta 
de consenso a respeito de quais os limites desta atuação e de como deve ser o sistema de divisão de competências entre as Casas Legislativas.

A pretensão do Senado de se afirmar como o órgão por excelência de controle das ações internacionais do Executivo se contrapõe ao desejo dos deputados de estender tais atribuições para a Câmara Baixa e ao temor de aprovar iniciativas que ampliem em demasia as faculdades da Câmara Alta. Esse jogo de forças entre as Casas Legislativas acaba enfraquecendo a legislação procedimental como instrumento hábil a guarnecer o Legislativo com mecanismos mais eficazes de atuação no âmbito da política externa

Ao mesmo tempo, ao contrário do sistema norte-americano, em que o poder de controle sobre o orçamento e as tarifas tem um peso importante sobre a condução da política externa, seu uso pelos congressistas mexicanos no período analisado se restringiu a um caso pontual, a taxação do xarope de milho, o qual ilustra de que forma a Câmara dos Deputados, mesmo não dispondo de atribuições constitucionais específicas na área internacional, pode influir sobre a política de comércio exterior.

Em que pese a importância da produção legislativa propriamente dita, entendemos que o indicador mais importante do nível de atividade em política externa, no caso do Congresso mexicano, são os pontos de acordo ("puntos de acuerdo"). Conforme destaca Velazquez (2007), houve um progressivo aumento do número de pontos de acordo apresentados pelos congressistas à medida que avançou o processo de democratização no país.

Os pontos de acordo, embora não apresentem caráter vinculativo, podendo ou não ser acatados pelo Executivo, são os instrumentos legislativos por excelência por meio dos quais os congressistas expõem seus pontos de vista sobre temas internacionais, emitem protestos contra determinados atos, solicitam explicações e informações, exortam o Executivo a empreender ações e censuram atos do Executivo.

O conteúdo variado e a forma mais livre dos pontos de acordo os torna um mecanismo de uso mais corrente pelos congressistas, como uma primeira forma de manifestação diante de ações empreendidas em âmbito internacional com reflexos sobre o país. As observações referentes aos pontos de acordo valem também para os acordos parlamentares, que cumprem função semelhante, com a diferença de serem fruto de consenso entre as lideranças partidárias. 
No período analisado, foram apresentados 992 pontos de acordo, dos quais 522 foram aprovados, 377 permanecem pendentes de votação e 93 foram rejeitados. Foram também aprovados 75 acordos parlamentares.

Algumas temáticas são bastante recorrentes nos pontos de acordo, revelando uma especial preocupação dos congressistas em relação a estes aspectos. Entre os temas de elevada incidência, é possível citar a política migratória dos Estados Unidos, que abrange a situação dos mexicanos ilegais, a violência contra eles praticada e a passagem de veículos na fronteira; a revisão do capítulo agropecuário do NAFTA; e a postura do México em relação a Cuba na Assembléia das Nações Unidas.

No caso específico da relação com Cuba, durante o Governo Fox, foram aprovados diversos pontos de acordo pelo Congresso, incitando o Presidente a não votar a favor de resoluções contra o país na ONU, bem como a se posicionar a favor do levantamento do embargo econômico imposto à Ilha.

No tocante a outros meios indiretos de influência, a exemplo da participação dos congressistas em organismos internacionais e da realização de reuniões e viagens internacionais, o levantamento de dados ficou parcialmente prejudicado, tendo em vista a impossibilidade de realização de trabalhos de pesquisa in loco, que permitissem a diversificação das fontes informativas.

Os endereços eletrônicos da Câmara dos Deputados e do Senado possuem esse tipo de dado apenas em relação às duas últimas Legislaturas (LX e LXI), as quais fogem ao horizonte temporal utilizado como referência na pesquisa. Por conseguinte, optamos por apenas pontuar os organismos internacionais de que participam os congressistas mexicanos, como indicativo de um esforço de compartilhamento de informações e de especialização do Legislativo em temas internacionais.

Outro meio indireto de influência apontado por Lindsay, o recurso a meios de comunicação de massa, foi um instrumento utilizado com certa freqüência pelos congressistas para expor seus posicionamentos em temas de política externa. Artigos publicados nos endereços eletrônicos oficiais do Congresso e dos partidos políticos mexicanos, entrevistas e publicações em periódicos foram encontrados no decorrer do processo de pesquisa, embora não estejam traduzidos em números no trabalho. 
De um modo geral, os indicadores utilizados para medir o nível de atividade do Congresso mexicano relevam um ativismo progressivo, que é alavancado sobretudo durante o Governo Fox, em que a situação de governo dividido permitiu ao Legislativo encontrar maior espaço para o exercício de suas prerrogativas em matéria de política externa.

A segunda variável, nível de divergência, foi medida a partir de dois indicadores: a) nível de divergência em temas de política externa entre os partidos políticos mexicanos, expresso por meio de suas plataformas eleitorais das eleições de 2006; b) nível de divergência do Congresso em relação ao Executivo, manifestado por meio do exercício do seu poder de veto e pelos principais pontos de atrito entre os poderes no decorrer das legislaturas analisadas.

As plataformas eleitorais analisadas permitem contrastar dois projetos políticos distintos: de um lado, a proposta panista de dar continuidade e aprofundar as diretrizes básicas da política externa de Fox, calcada em um alinhamento estratégico com os Estados Unidos através de iniciativas como a ASPAN e, de outro, o projeto perredista com foco nos interesses nacionais e na diminuição da dependência em relação aos norteamericanos. Articulando a disputa política, o PRI apoiou-se na defesa do retorno aos cânones tradicionais de condução da política externa mexicana.

As eleições de 2006 apresentaram um quadro mais amadurecido das posições dos principais partidos políticos mexicanos, constituindo um importante preditor do nível de divergência entre os projetos políticos para o México no plano internacional e um indicativo do processo de politização da política externa, que assumiu um importante viés doméstico.

No que tange ao exercício do poder de veto pelo Congresso, os dados coletados no Sistema de Informação Legislativa da Secretaria de Governo do México revelam uma tendência do Congresso, ao longo das quatro legislaturas estudadas, de aprovar por unanimidade ou com pequena margem de votos em sentido contrário os instrumentos internacionais, pedidos de viagem, autorizações para uso de condecorações conferidas por países estrangeiros e organismos internacionais e nomeações diplomáticas.

Dos 482 instrumentos internacionais apresentados perante o Congresso entre 1994 e 2006, apenas 7 foram rejeitados - nestes casos, com exceção de um deles, todos os 
congressistas votaram a favor da rejeição - 13 permaneceram pendentes e 473 foram aprovados. Dos 473 tratados aprovados, apenas 26 deles receberam ao menos um voto em sentido contrário. A maioria dos instrumentos que apresentaram votação mais apertada possuíam temáticas com efeitos distributivos, a exemplo de acordos de cooperação econômica e de proteção recíproca de investimentos (APRI’s).

Portanto, o exercício de seu poder de veto, decorrente das faculdades constitucionais de ratificação de instrumentos internacionais e de concessão de autorizações, não tem sido o principal instrumento utilizado pelo Congresso, em especial pelo Senado, que detém a maioria destas atribuições, para impor suas preferências no âmbito da política externa.

$\mathrm{Na}$ análise realizada, não foram encontrados elementos concretos que permitissem afirmar que, nas hipóteses de aprovação por unanimidade ou com pequena proporção de votos em sentido contrário, tenha havido antecipação das reações dos congressistas pelo Executivo, um dos instrumentos de influência apontados por Lindsay. O argumento aqui sustentado caminha em sentido oposto: o histórico do comportamento do Congresso torna pouco crível para o Executivo uma ameaça de veto nestes casos, o que aumenta a sua liberdade para negociar, independentemente das preferências dos congressistas.

Contudo, merece destaque o fato de, durante o Governo Fox, a rejeição de pedidos de autorização de viagem internacional do Presidente da República ter sido utilizada por duas vezes pelo Congresso para manifestar sua discordância em relação às diretrizes de condução da política externa pelo Executivo. Esses dois episódios ilustram o exercício do poder de veto pelo Congresso para fazer frente ao Executivo, o que não constitui a regra no comportamento do Legislativo ao longo do período analisado.

Se, do ponto vista quantitativo, o comportamento do Congresso apresentou pequenas modificações no confronto entre os dois blocos de legislaturas analisados, com predomínio das aprovações por unanimidade; qualitativamente o cenário foi distinto. A dinâmica da relação entre o Executivo e o Congresso em temas de política externa modificou-se com a passagem do Governo Zedillo (1994-2000) para o Governo Fox (2000-2006), reflexo das mudanças de orientação na política externa mexicana e da alteração na composição das Casas Legislativas, em que o novo partido do governo, o PAN, deixou de contar com maiorias. 
Durante o Governo Zedillo, o Congresso apresentou uma postura predominantemente passiva em relação às temáticas internacionais. $\mathrm{O}$ alinhamento entre PRI e PAN criou dificuldades para que se estruturasse uma verdadeira oposição, conduzindo ao isolamento do PRD. O resultado foi um fraco sistema de separação de poderes, com predomínio do presidencialismo forte e de um Congresso apático, controlado pelas maiorias do PRI, pouco disposto a confrontos na arena política. Temas como a imigração, a relação com Cuba e a assinatura de Acordos de Proteção Recíproca de Investimentos (APRI's) geraram certo desconforto entre os poderes, culminando em algumas manifestações do Congresso, as quais não chegaram a comprometer ratificações ou levar o Executivo a mudanças de orientação.

Esta situação se alterou com a eleição de Vicente Fox para a Presidência da República em 2000. Pela primeira vez na história política mexicana, o Congresso apresentou-se como um ator disposto a disputar espaços de poder na formulação e condução da política externa, tomando posições independentes e tentando ampliar suas atribuições por meio de reformas legislativas. Essa nova postura resultou em constantes atritos entre os poderes em temas delicados, como a relação com Cuba e com os outros países latino-americanos e a cooperação na área de segurança com os Estados Unidos, colocando em funcionamento um tíbio sistema de freios e contrapesos.

Entretanto, as ações de confronto ao Executivo empreendidas pelo Congresso não produziram os resultados esperados de mudança na orientação da política externa de Fox, que, mesmo acusado pelos congressistas de violar os cânones tradicionais de condução do México no plano internacional, ignorou em diversas oportunidades as manifestações do Legislativo e deu continuidade ao seu projeto político inicial. As tentativas do Congresso de resolver sozinho situações críticas também resultaram em fracasso. Exceção feita talvez ao caso de Cuba, já no final das negociações para o restabelecimento das relações diplomáticas entre os países, em que as pressões dos congressistas ganharam certo relevo.

No México, o binômino liberalização econômica e abertura política conduziu a um aumento da mobilização do Congresso em temas de política externa, confirmando a hipótese sustentada por Maria Regina Soares de Lima e Fabiano dos Santos. Este aumento de mobilização se traduziu em um maior ativismo - nível de atividade - porém 
as ações desenvolvidas se mostraram pouco eficientes em representar um contrapeso efetivo ao Executivo, isto é, foram pouco assertivas.

A despeito do elevado nível de divergência em relação a algumas posições do Executivo, em especial durante o Governo Fox, o Congresso demonstrou baixa capacidade institucional para impor suas preferências. As mobilizações em torno de temas de política externa conseguiram, no máximo, moderar a atuação do Executivo em casos pontuais. Quando a preferências dos poderes se mostraram inconciliáveis, prevaleceu a força tradicional do Executivo no âmbito externo.

A negociação da ASPAN nos marcos de um acordo executivo é representativa de uma das estratégias do Executivo que, derrotado no plano doméstico na aprovação de reformas constitucionais relacionadas ao setor energético, valeu-se de seu poder de controle de agenda nas negociações internacionais para alijar o acordo da apreciação do Congresso, evitando uma possível rejeição.

O comportamento do Congresso mexicano ao longo das quatro legislaturas analisadas caracterizou-se, portanto, por um progressivo nível de ativismo, com o aumento do número de ações levadas a cabo no âmbito da política externa, e por níveis baixos de assertividade, uma vez que o sistema de freios e contrapesos entre os poderes funcionou de forma débil, sem ameaçar o domínio do Executivo nesta seara.

Sugerimos, como linha de pesquisa a ser desenvolvida no futuro, que as limitações do Congresso mexicano para atuar no domínio da política externa decorrem de fatores estruturais, como os custos de rejeição de compromissos assumidos pelo país no plano internacional, os quais fazem com que os legisladores tolerem ações além das suas curvas de indiferença; e conjunturais, relacionados à realidade mexicana, como a falta de consenso no interior das Casas Legislativas sobre o papel a ser desempenhado pelo Congresso, o uso doméstico das atribuições de política externa e a percepção dos efeitos decrescentes dos tratados internacionais após a agressiva abertura econômica produzida pelo NAFTA.

As conclusões desenvolvidas neste trabalho estão limitadas pelo recorte temporal adotado. A escolha das Legislaturas LVI a LIX como objeto de análise fundamentou-se no interesse em confrontar o comportamento do Congresso mexicano em temas de política externa em dois cenários distintos: o domínio das maiorias do PRI, 
correspondente às LVI e LVII Legislaturas, sob a Presidência de Ernesto Zedillo; e o governo dividido, correspondente às LVIII e LIX Legislaturas, sob a Presidência de Vicente Fox.

O prazo para o desenvolvimento da pesquisa impediu que a análise abrangesse um maior número de legislaturas, as quais permitiriam traçar um quadro mais maduro do comportamento do Congresso na nova situação de um governo sem maiorias. Os argumentos sustentados nesta dissertação se apóiam um em cenário inicial de mobilização, cujas características podem ser profundamente alteradas com o avanço do processo democrático no país.

Esse esforço de reflexão sobre as primeiras respostas do Congresso mexicano no campo da política externa busca chamar atenção para um tema que tem recebido tratamento marginal da literatura latino-americana. Quiçá os trabalhos futuros logrem demonstrar que o crescimento da atuação dos Congressos nacionais no domínio da política externa é um fenômeno comum a maior parte dos países latino-americanos, cuja pesquisa deve ser fomentada. 


\section{REFERÊNCIAS BIBLIOGRÁFICAS}

ALISSON, Graham. (1971), Essence of decision: explaining the Cuban Missile Crisis. Boston, Litlle Brown and Company.

BEJAR, Luisa. (2007), “Cambio institucional: el congreso mexicano después de la alternancia”. Documento apresentado no VII Congreso Español de Ciencia Politica y de la Administración: Democracia y Buen Gobierno, Grupo de Trabalho 19, Parlamentos: instituciones para el buen gobierno democrático. Disponível em: http://www.aecpa.es/archivos/congresos/congreso_07/area05/GT19/BEJARLuisa(UNAM -Mexico).pdf. Acesso em 01.03.2009.

BERRUETO, Eliseo Mendoza. (2006), "Política exterior y la acción de los parlamentos: el caso de Mexico". Revista del Senado Mexicano, n 5, vol. 2.

CAMERON, Maxwell A.; TOMLIN, Brian W. (2000), The Making of NAFTA. Ithaca, New York, Cornell University Press.

CARPIZO, Jorge. (1978), El presidencialismo mexicano. México, D.F. Siglo XXI.

CASAR, Maria Amparo. (1996), "Las bases político-institucionales del poder presidencial en México". Política y gobierno, vol. III, n 1 , primer semestre. . (2002), "Executive-Legislative Relations: The case of Mexico (1947-2000)" in MORGENSTERN, SCOTT and NACIF, Benito, Legislative Politics in Latin America, Cambrigde University Press.

CASILLAS, Carlos Enrique. (2003), "Desencuentros de la política exterior mexicana: presidente y senado 2000-2003”. El cotidiano, vol. 19, n 120, pp. 57-63, julio-agosto.

CHABAT, Jorge (1986), "El marco jurídico de la política exterior: tendencias y perspectivas". Cuadernos de politica exterior mexicana 2, México, CIDE, pp. 15-42.

(1989), "La toma de decisiones en la politica exterior mexicana", in

GREEN, Rosario e SMITH, Peter (coords), Retos en las relaciones entre México y Estados Unidos. México, FCE- Comisión para el Futuro de las relaciones MexicoEstados Unidos, pp. 87-124.

(2006), "The Vicious Circle of Nationalism: How the Mexican Elites

Created the Myth of Anti-U.S. Feelings". Paper apresentado no Encontro Anual da International Studies Association (ISA). 
CRABB, Cecil V. e HOLT, Pat. M. (1980), Invitation to Struggle: Congress, the President and Foreign Policy. Washington, Congressional Quarterly Press.

CORTELL, Andrew P.; PETERSON, Susan. (2003), "Agents, structures and domestic institucional change" in CORTELL, Andrew P.; PETERSON, Susan (eds) International Relations, Politics and Institucional Change. Oxford, Lexington Books.

COSSIO, D., RODRIGUEZ, José Ramon., HUERTA, Gabriela. (2003), El senado de la República y las relaciones exteriores. México, D.F. Miguel Angelo Porrúa, Senado de la República/ITAM.

DAHL, Robert. (1950). Congress and foreign policy. New York, Harcourt, Brace.

DÁVILA, Consuelo. (2006), "The Role of Political Parties in the Mexican Foreign Policy". Paper apresentado no 49 Convenção Anual da ISA. São Francisco, 26-29 de março.

DINIZ, Simone; RIBEIRO, Claudio Oliveira. (2008), "The role of the Brazilian Congress in Foreign Policy: an Empirical Contribution to the Debate". Brazilian Political Science Review, vol. 2, nº 2, pp. 10-38, dezembro.

FELIÚ, Pedro R. (2008), Votações nominais, espectro ideológico político partidário e política externa: o caso chileno (1994-2006). Dissertação de Mestrado defendida no Departamento de Ciência Política da Universidade de São Paulo.

FLORES, Rafael Velázquez. (2007), "La relación entre el Ejecutivo y el Congreso em materia de política exterior durante el sexenio de Vicente Fox: cooperación o conflicto?”. Documento de Trabalho $\mathrm{n}^{\circ}$ 164, CIDE, octubre. . (2008), "The executive-legislative relationship in Foreign Policy making: conflict or cooperation”. Paper apresentado na 49 Convenção Anual da International Studies Association (ISA), São Francisco, Califórnia, march 26-29.

FLORES, Rafael Velázquez; DOMÍNGUEZ, Roberto. (2007), "México contra todos: un analisis del proceso de toma de decisiones en las crisis diplomaticas con Cuba, Argentina e Venezuela". Foregin Affairs en Español. Vol. 7, n 02, abril-junio.

GARCIA, Elma del Carmen Trejo. (2006), "Alianza para la seguridad y la prosperidad de América del Norte (ASPAN)". Servicio de investigación y análisis, División de Política Externa, Camara de Diputados México, LIX Legislatura, julio. 
GONZÁLEZ, Guadalupe González. (2005), "Las bases internas de la política exterior: realidades y retos de la apertura económica y la democracia”. México, Documento de Trabalho $\mathrm{n}^{\circ} 131$, CIDE. . (2007), "Democratización y política exterior: ¿el fin del predominio presidencial? México, Documento de Trabalho $\mathrm{n}^{\circ}$ 161, CIDE.

HAGGard, S.; MCCUbBInS, M. (ed.). (2001), Presidents, Parliaments and Policy. New York, United States, Cambridge University Press.

HENEHAN, Marie T. (2003), Foreign Policy and Congress: an international relations perspective. The University of Michigan Press.

HILL, Christopher. (2003), The changing politics of foreign policy. Grã-Bretanha, Palgrave Macmillan.

HINCKLEY, Barbara. (1978), Stability and Change in Congress. New York, Harper and Row. .(1994), Less than Meets the Eye: The Myth of a Assertive Congress.Chicago, University of Chicago Press.

HUDSON, Valerie. (2005), "Foreign Policy Analysis: Actor-Specific Theory and the Ground of International Relations". Foreign Policy Analysis, vol. 1, pp. 1-30.

HUFBAUER, G. C.; SCHOTT, J. J. (2005), NAFTA Revisited: Achievements and Challenges. Institute for International Economics.

HURRELL, Andrew. (2003), "Political Regimes and Foreign Policies: An Introduction" in José Flávio Sombra Saraiva (ed.), Foreign Policy and Political Regime, Brasília, IBRI/UnB, pp. 29-63.

KAHLER, M. (Ed.). (1997), Liberalization and foreign policy. New York, Columbia University Press.

LEÃO, Flavio. (2008), "Poder Legislativo e política externa: um estudo sobre a influência do Congresso nacional do Chile na formulação da política comercial durante a década de 90". Contexto Internacional, vol. 30, nº 1, pp. 89-139, janeiro/abril.

LIMA, Maria Regina Soares. (2000), "Instituições Democráticas e Política Exterior”. Contexto Internacional, vol. 22, Julho/Dezembro, pp. 265-303.

LIMA, Maria Regina Soares e SANTOS, Fabiano. (2001), "O Congresso e a Política Exterior”. Lua Nova, n 52 , pp. 121-150. 
Foreign Trade Policy. Trabalho apresentado no XXI Encontro da Latin American Studies Association (LASA). Chicago, 24-26 de setembro.

LINDSAY, James. (1994a), Congress and the Politics of US Foreign Policy. Baltimore, Maryland, The Johns Hopkins University press. .(1994b), "Congress, Foreign Policy, and the New Institucionalism". International Studies Quarterly, vol. 38, n² 2, Jun. 1994, pp. 281-304. . (1992/1993). "Why the Hill Matters". Political Science Quarterly, vol. 107, $\mathrm{n}^{\circ}$ 4, Winter, pp. 607-628.

MANSFIELD, Edward D.; SNYDER, Jack. (1995), "Democratization and the Danger of War”. International Security, no 20, pp. 5-38.

MARTIN, Lisa. (2000), Democratic commitments: legislatives and international cooperation. Princeton, Princeton University Press.

MENA, Antonio Ortiz. (2004a), "O processo de formulação política de comércio nas Américas: lições da experiência mexicana”. Trabalho apresentado para a $45^{\text {a }}$ Convenção Anual da ISA em Montreal, Canadá. . (2004b), "Mexico’s Trade Policy: Improvisation and Vision" in

Aggarwal, V. K. et al. (eds), The Strategic Dynamics of Latin American Trade, Washington, Stanford University Press. . (2006), "The Domestic Determinants of Mexico's Trade Strategy"

in R. Bouzas (ed.), Domestic Determinants of National Trade Strategies, Paris, Chaire MERCOSUR de Science Po.

MENDÉZ, Guadalupe. (2003), “Democratización, pluralización y cambios em el sistema de partidos en México, 1991-2000”. Revista Mexicana de Sociología, vol. 65, no 3, julhosetembro, pp. 523-564.

MILNER, Helen V. (1997), Interests, Institutions and Information. Princeton, New Jersey, Princeton University Press.

MILNER, Helen V., ROSENDORFF, Peter B., MANSFIELD, Edward D. (2000), "Free to Trade: democracies, autocracies, and international trade”. The American Political Science Review, vol. 94, n 2, Junho, p. 305-321. 
MONTEJANO, Claudia Gamboa; ROBLEDO, Sandra Valdés. (2005). "Lineamentos Constitucionales de la Política exterior en México". Servicio de investigación y análisis, División de Política Interna, Camara de Diputados México, LIX Legislatura. MORAVCSIK, Andrew. (2000), "The Origins of Human Rights Regimes: Democratic Delegation in Postwar Europe". International Organization, vol. 54, $\mathrm{n}^{\circ} 2$. MORGENTHAU, Hans J. (1948), Politics among Nations. New York, Alfred A. Knopf. NACIF, Benito. (2005), "The fall of the dominant presidency: lawmaking under divided government in Mexico". Paper apresentado na conferência "Qual tipo de democracia tem o México? A evolução do presidencialismo e do federalismo", CIDE, USCD, março de 2005. .(2003), "Policy Making under Divided Government in Mexico". México, Documento de Trabalho CIDE, nº 305.

NETO, Octavio Amorim \& SCHIAVON, Jorge A. (2004), "Las condicionantes internas de la política exterior de Brasil y México". México, Documento de Trabalho CIDE, $\mathrm{n}^{\circ}$ 108.

OLIVEIRA, Amâncio Jorge de. (2003), "Legislativo e Política Externa: das inconveniências da abdicação". Working Papers CAENI , nº 3, São Paulo.

OLIVEIRA, A., FELIÚ, P., GALDINO, M • (2007), "Ideology, Foreign Policy and the Congress: the Chilean case (1998-2006)". Apresentado no Encontro Nacional da ANPOCS, Caxambu, MG, Brasil.

PIERSON, Paul. (2003), "Big, slow-moving, and ... invisible: macro-social processes in the study of comparative politics ". in D. Rueschemeyer, and J. Mahoney. Comparative Historical Analysis in the Social Sciences. Cambridge University Press, pp. 177-207. POITRAS, G. e ROBINSON, R. (1994), "The politics of NAFTA in México". Journal of Interamerican Studies and World Affairs, vol. 36, $\mathrm{n}^{\circ}$ 1, pp. 1-35.

PURCELL, Susan Kaufman. (2004), "The Changing Bilateral Relationship: A U.S. View", in Luis Rubio e Susan Kaufman Purcell, eds., Mexico under Fox, Boulder, Lynne Rienner, pp. 143-164.

PUTNAM, Robert D. (1998), "Diplomacy and Domestic Politics: The logic of two-level games". International Organization, vol. 42, nº 3. 
RAMÍREZ, Manuel Becerra. (2005), “Ley sobre la aprobación de tratados internacionales en materia económica”. Anuario Mexicano de Derecho Internacional, vol. V, pp. 697-704.

ROBINSON, James A. (1962), Congress and Foreign Policy-Making: a Study in Legislative Influence and Initiative. New York, Dorsey.

ROSAS, Maria Cristina. (2002), Mexican Trade Policy in the New Millennium. APEC Study Center of Developing Economies.

ROSATI, Jerel A. (1984), "Congressional Influence in American Foreign Policy: Adressing the Controversy". Journal of Political and Military Sociology nº. 12, pp. 311333.

ROSENAU, James N. (1971). "Foreign Policy as an issue area" in James N. Rosenau (ed.), The Scientific Study of Foreign Policy, New York, Free Press, pp. 401-440.

ROURKE, John T. (1983), Congress and the Presidency in U.S. Foreign Policymaking: a Study of Interaction and Influence. Boulder, CO, Westview.

. (1987), "Perception, the two-president thesis, and the Reagan administration". Paper apresentado no encontro annual Northeast International Studies Association, Philadelphia, Novembro.

SAEZ, Sebastian. (2005), Implementing Trade Policy in Latin America: the case of Chile and Mexico. ECLAC, Santiago.

SARAIVA, José Flávio Sombra. (2003), "Is It Possible to Establish a Causal Nexus Between Foreign Policy and Political Regime?” in José Flávio Sombra Saraiva (ed.), Foreign Policy and Political Regime, Brasília, IBRI/UnB, pp. 13-27.

SCHIAVON, J.A.; MENA, A.O. (2001a), "Liberalización Comercial y Reforma Burocrática en el área de tratados comerciales internacionales en México (1988-2000)”. México, Documento de Trabalho nº 69, CIDE.

- (2001b), “Apertura Comercial y Reforma

Institucional en México (1988-2000): Un Análisis Comparado del TLCAN y el TLCUE”, Foro Internacional, octubre-diciembre.

SOLANA, Fernando. (1996) "El papel del Senado en la politica exterior mexicana". Revista de Administración Pública, no 92, pp. 195-204. 
. (2000) Seis años de diplomacia parlamentaria 1994-2000. Mexico,

Limusa.

STUHLDREHER, Amalia. (2003), "Regimen Político y Politica Exterior en Argentina:

El caso del primer gobierno de Carlos Menem (1989-995)". Perfiles Latinoamericanos, Junio, $\mathrm{n}^{\circ} 22$.

SUNDQUIST, James L. (1981), The Decline and Ressurgence of Congress. Washington, Brookings Institution.

TSEBELIS, George. (1997), "Processo Decisório em Sistemas Políticos: veto players no presidencialismo, parlamentarismo, multicameralismo e pluripartidarismo". São Paulo, Revista Brasileira de Ciências Sociais, vol. 12, nº 34, pp. 89-118.

WALTZ, K. (1979), Theory of International Politics. Reading, MA, Addison-Wesley.

WELDON, Jeffrey. (1997), "The Political Sources of Presidencialimo in Mexico", in

Scott Mainwaring y Matthew S. Shugart (eds.), Presidentialism and Democracy in Latin

America, New York, Cambridge University Press.

WILDAVSKY, Aaron. (1966), "The two presidents". Trans-Action 4, pp.7-14.

VÁZQUEZ, Alba Gaméz. (2006), Liberalización Económica y política exterior em México, 1989-1994. México, D.F., Plaza y Valdes Editores.

\section{LEGISLAÇÃo}

México. Constitución Política de los Estados Unidos Mexicanos, de 5 de fevereiro de 1917. Diário Oficial de La Federación, 5 fev. 1917.

México. Ley sobre la Aprobación de Tratados Internacionales en Materia Económica, de 2 de setembro de 2004. Diário Oficial de La Federación, 2 set. 2004.

México. Ley sobre la Celebración de Tratados, de 2 janeiro de 1992. Diário Oficial de La Federación, 2 jan. 1992.

México. Ley Orgánica de la Administración Pública Federal, de 19 de dezembro de 1976. Diário Oficial de La Federación, 29 dez. 1976.

México. Reglamento para el Gobierno Interior del Congreso General de los Estados Unidos Mexicanos, de 20 de março, 1934. Diário Oficial de La Federación, 20 mar. 1934. 